\title{
Archeological Investigations at the Hudnall-Pirtle Site (41RK4) An Early Caddo Mound Center in Northeast Texas
}

James E. Bruseth

Unknown

Timothy K. Perttula

Heritage Research Center, Stephen F. Austin State University

Gayle J. Fritz

Bonnie C. Yates

Follow this and additional works at: https://scholarworks.sfasu.edu/ita

Part of the American Material Culture Commons, Archaeological Anthropology Commons, Environmental Studies Commons, Other American Studies Commons, Other Arts and Humanities Commons, Other History of Art, Architecture, and Archaeology Commons, and the United States History Commons

Tell us how this article helped you.

This Article is brought to you for free and open access by the Center for Regional Heritage Research at SFA ScholarWorks. It has been accepted for inclusion in Index of Texas Archaeology: Open Access Gray Literature from the Lone Star State by an authorized editor of SFA ScholarWorks. For more information, please contact cdsscholarworks@sfasu.edu. 


\section{Archeological Investigations at the Hudnall-Pirtle Site (41RK4) An Early Caddo}

Mound Center in Northeast Texas

\section{Creative Commons License}

\section{(c) (1) \&}

This work is licensed under a Creative Commons Attribution-NonCommercial 4.0 International License 


\title{
Archeological Investigations at the Hudnall-Pirtle Site (41RK4) An Early Caddo Mound Center in Northeast Texas
}

\author{
James E. Bruseth and Timothy K. Perttula, \\ with Contributions by Gayle J. Fritz and Bonnie C. Yates
}

\section{INTRODUCTION}

The Hudnall-Pirtle site (41RK4) is situated on a large T-1 alluvial terrace of the Sabine River in northern Rusk County in Texas (Figure 1). This area of the state, commonly called Northeast Texas, is part of the Southern Gulf Coastal Plain, a relatively level, sloping plain formed by the pre-Pleistocene embayment of the Gulf of Mexico.

From a biogeographical perspective, the site is located in the Oak-Hickory-Pine forest of eastern Texas, otherwise known as the Pineywoods. This area represents the western extension of the southern coniferous forests and is dominated by shortleaf and loblolly pine trees (Jordan et al. 1984:28). Hardwood trees, including various oaks, hickory, elm, and gum, are the dominant vegetation in the floodplains of rivers and major creeks in Northeast Texas.

Soils consist of light-colored to dark-colored sands and sandy loams, with denser clays in the floodplains of major rivers and creeks (see Griffith 2001). The soils have been heavily leached by relatively high rainfall that ranges from 40-50 inches per year (Bomar 1983). Soils are generally acid, causing poor preservation of faunal remains in archeological deposits.

The first written description of the Hudnall-Pirtle site is contained in an unpublished manuscript by amateur historian William Woldert from Tyler, Texas. In a section of the manuscript about old Indian trails, Woldert (1932) describes a "Mound Trail" that crossed the Sabine River in northern Rusk County and passed near a mound that is almost certainly part of the Hudnall-Pirtle site. Woldert provides directions and distances to the mound from several surrounding towns, and when plotted, these measurements correspond almost exactly to the location of the Hudnall-Pirtle site.

The Hudnall-Pirtle site was officially recorded in the 1930s during a University of Texas (UT) archeological survey sponsored by the Works Progress Administration (WPA). A.M. Woosley of the WPA-UT program located the site on the basis of information supplied by surrounding landowners and recorded it as consisting of a "medium sized earth mound" (Woosley 1939). Noting only a single mound is perhaps understandable given the heavy vegetation that likely covered the site at the time, but if Woosley had spent any time walking over the area he almost certainly would have noted the presence of several other earthen mounds. In many respects, though, it is fortunate the site was recorded as having only one mound because this placed it in a class of sites with numerous examples in eastern Texas. If the site's true size and significance had been properly understood, almost certainly the WPA-UT archeologists would have wanted to excavate it. Because of the relatively rudimentary techniques of the time, the Hudnall-Pirtle site would likely have been excavated with little attention 


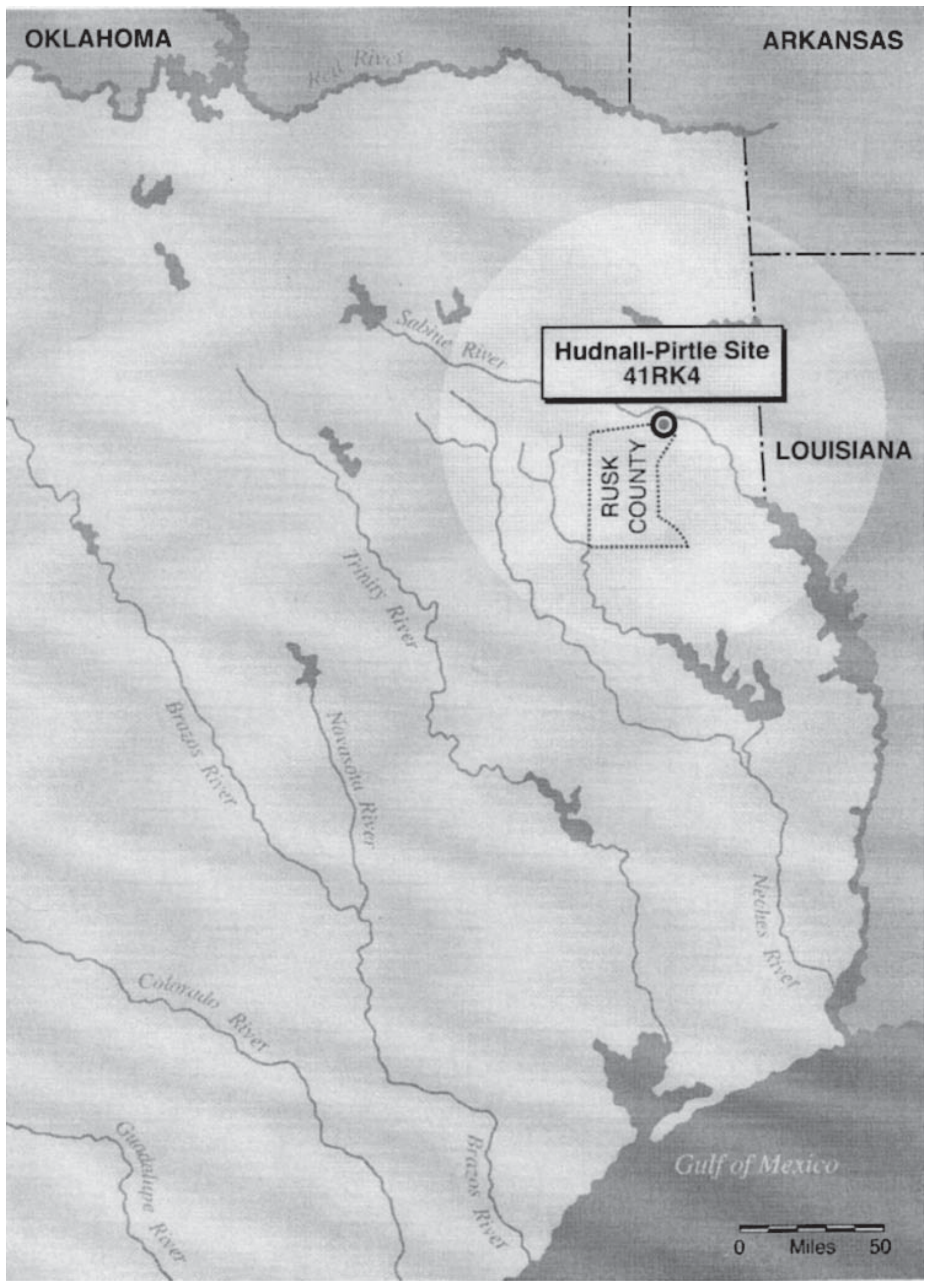

Figure 1. Location of the Hudnall-Pirtle site in Rusk County in Northeast Texas. 
to note taking and with great emphasis on obtaining display-quality artifacts.

The next mention of the site appears in the published transcripts of the Seventh Caddo Conference, held in 1963 (Davis et al.1971). During a transcribed and published discussion of diagnostic artifact traits from early Caddoan period sites, then-amateur archeologist Calvin Jones presented the following information about the site:

[T] here is one big mound site (Bivins farm) located in the Sabine bottomlands of northeastern Rusk County. It is composed of five mounds arranged around a plaza; they consist of two large rectangular temple mounds and three large circular mounds. I would guess this site to be primarily of Alto origin although tests in the village area revealed Alto and Coles Creek sherds (Davis et al. 1971:101).

Surprisingly, none of the other archeologists attending the conference followed up with questions or comments about this previously unknown and obviously major Caddo mound center.

Jones conducted archeological investigations at the site during the mid-1960s. Although none of these investigations have been reported (and it is believed that ceramic sherds collected during that work are in the Jones collection at the Gregg County Museum in Longview, Texas), limited details about this effort could be gleaned from discussions with his mother, a long-time resident of Longview, now deceased. Jones appears to have spent much of his time working on what is labeled Mound $\mathrm{C}$ in Figure 2. He dug an east-west trench across the entire mound. The width of the trench is not known, but judging by the appearance of the mound today (the trenches were not backfilled), this trench must have been at least $1 \mathrm{~m}$ (about 3 feet) in width. A perpendicular trench oriented from the center of the mound to the south was also dug and appears to have been of equivalent width. According to Jones' mother, both trenches were dug to the bottom of the mound. The only artifact found was a "ceramic vessel with nodes on the exterior." Otherwise the mound, as described by Mrs. Jones, consisted of sterile "sugar sand."

Calvin Jones apparently concluded that the mound capped a sub-mound pit, likely a burial chamber, and decided to continue excavating deeper. However, the unconsolidated sands of the mound caused the trench walls to cave in, and he decided it was not safe to continue deepening the existing trenches. At this point, he enlisted Sam Whiteside of Tyler, Texas (see Walters 2005), to assist in the excavations. Whiteside later told James Bruseth that he had use of a front-end loader and had volunteered its use to help remove the mound fill and expose the subsurface pit. The front-end loader was transported to within a mile of the site before it began to rain. The rain was sufficiently heavy that the front-end loader could not continue to the site and was returned to Whiteside's house; this effort was never repeated. The rain, therefore, prevented the total excavation of Mound C.

The site was rediscovered by James Bruseth and Bob Skiles in the early 1980s by using the description in the Seventh Caddo Conference transcripts. The site was located, visited, and re-recorded. A one-meter-square unit was excavated in a large rectilinear mound (labeled as Unit A in Mound B in Figure 2). A tan sandy soil zone was present in this unit down to a depth of approximately $70 \mathrm{~cm}$ below surface (bs), where a reddish sandy clay zone was found. The unit was abandoned at about $1 \mathrm{~m}$ in depth. No artifacts were encountered.

A short time later Bruseth contacted The Archaeological Conservancy and explained the importance of the site and the need to permanently preserve it. Under the guidance of Jim Walker, the Conservancy's Southwest Regional Director, the site was acquired in 1986 and is today an archeological preserve.

The Texas Historical Commission (THC) conducted a series of short-term field projects at the site in 1989 and 1990. This work was carried out for two reasons. First, unknown to the Conservancy, a gas well and associated 


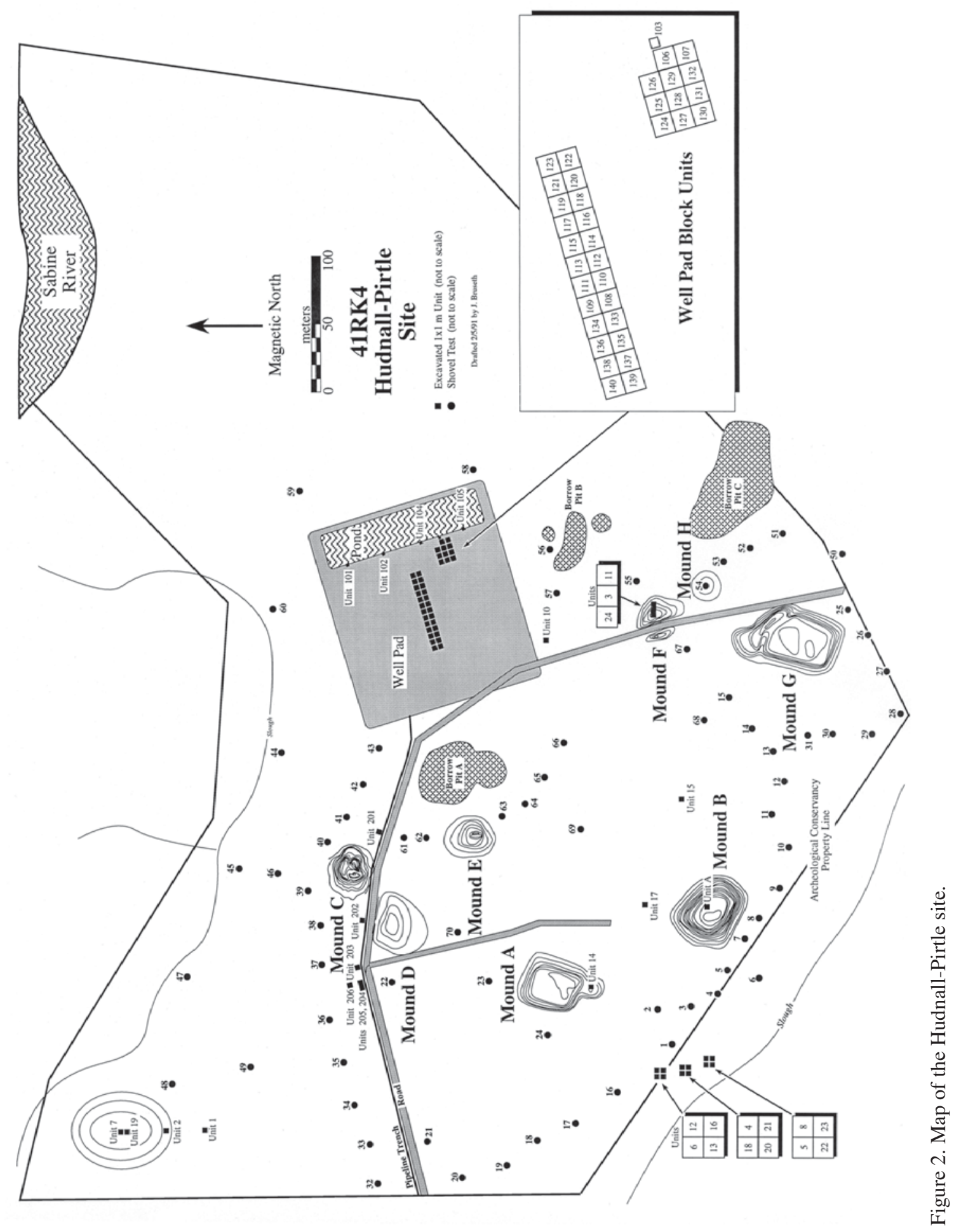


drilling sludge pit had been constructed on part of the site (see Figure 2), which had impacted some archeological deposits. A pipeline to connect the newly drilled well to an older line was planned for later in 1989. Fieldwork was therefore necessary to assess the drilling activity's impacts to the site.

Second, fieldwork at Hudnall-Pirtle was considered desirable in order to gain a better understanding of the site's size and the time periods it was used by Caddo people. The THC planned to nominate the site to the National Register of Historic Places, and the nomination form required additional information. The nomination was completed and accepted by the National Park Service, Keeper of the National Register in 1991. The fieldwork at the site resulted in the excavation of $651 \times 1 \mathrm{~m}$ square units and 70 shovel tests. Information about the fieldwork, by field season, is presented below.

\section{March 20-25, 1989}

This work focused primarily on mapping the site, showing the locations of mounds, borrow pits, modern roads, and well-exploration impacts (see Figure 2). Some limited testing was also undertaken on the edge of the gas well's sludge pit and along the pipeline trench to the gas well (Figure 3). to better understand the nature of the impacts to the archeological deposits. This fieldwork also focused on a very large mound (located in the northwest corner of the site (as shown in Figure 2) to determine if this elevation was natural or created by humans. A final goal was to search for other mounds that may exist in the wooded area around the central plaza. Contour maps were prepared of the existing mounds A-G (Figures 4-10).

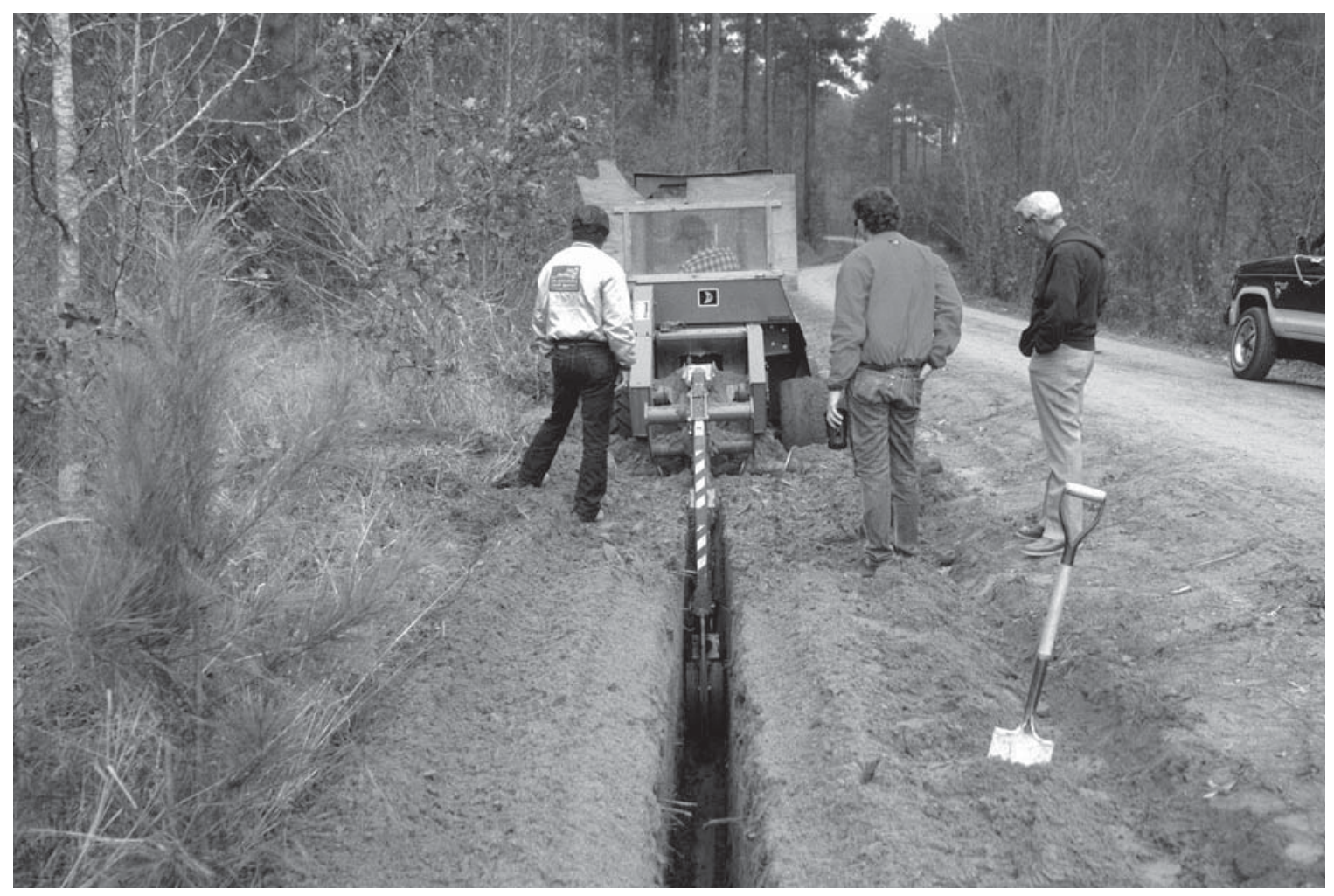

Figure 3. Digging of the pipeline trench to the gas well. 


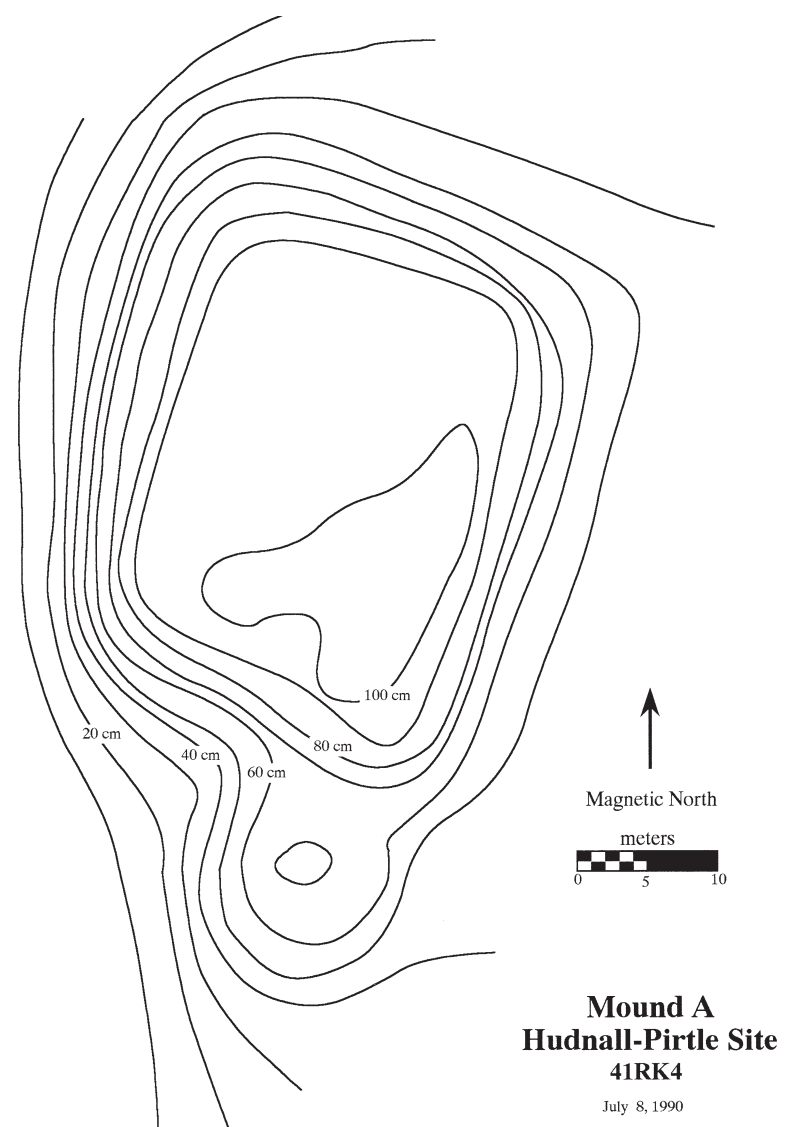

Figure 4. Contour map of Mound A.

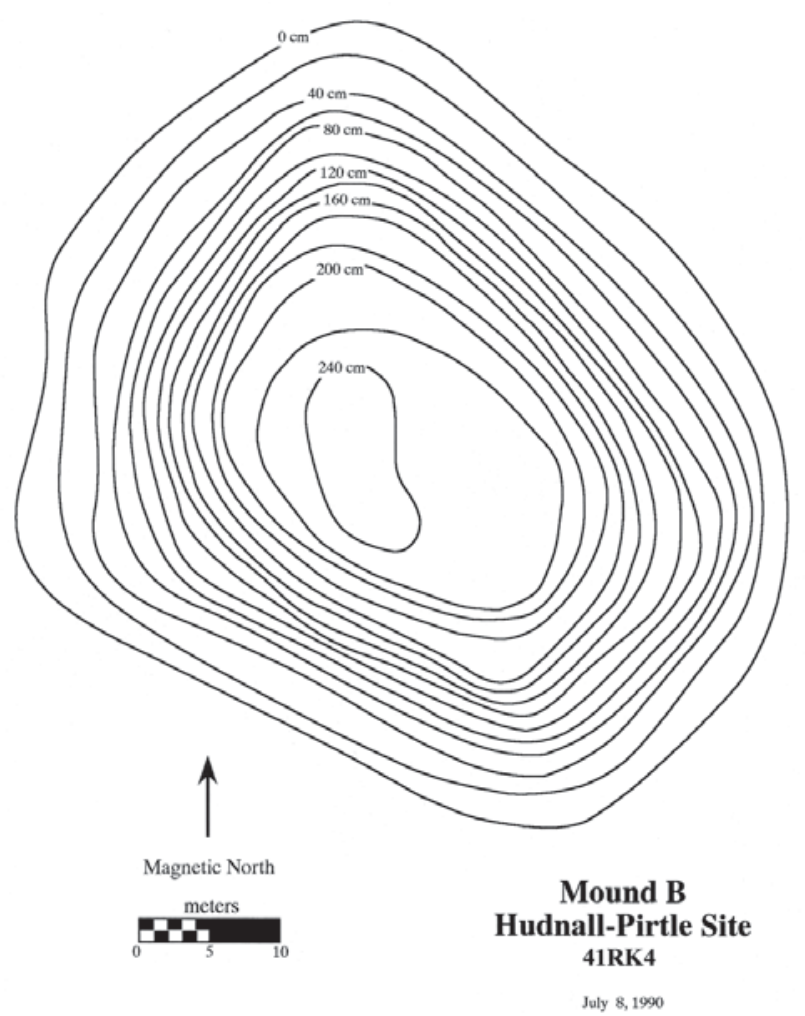

Figure 5. Contour map of Mound B 


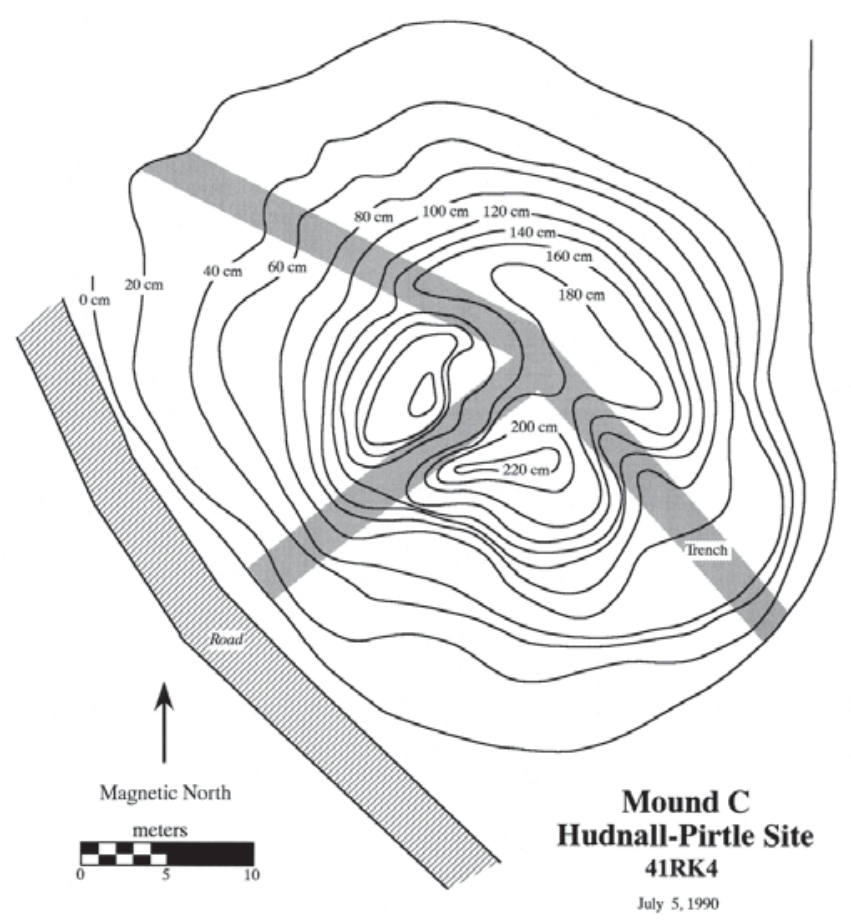

Figure 6. Contour map of Mound C; note trenches excavated by Calvin Jones in the early 1960s.

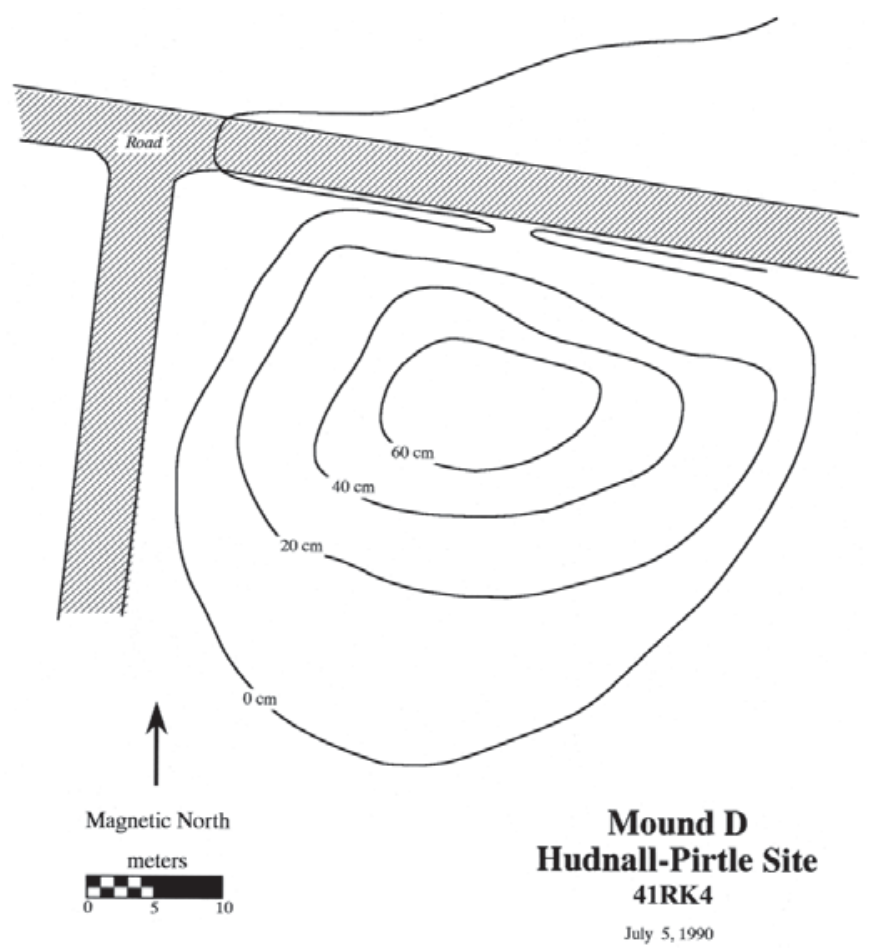

Figure 7. Contour map of Mound D. 


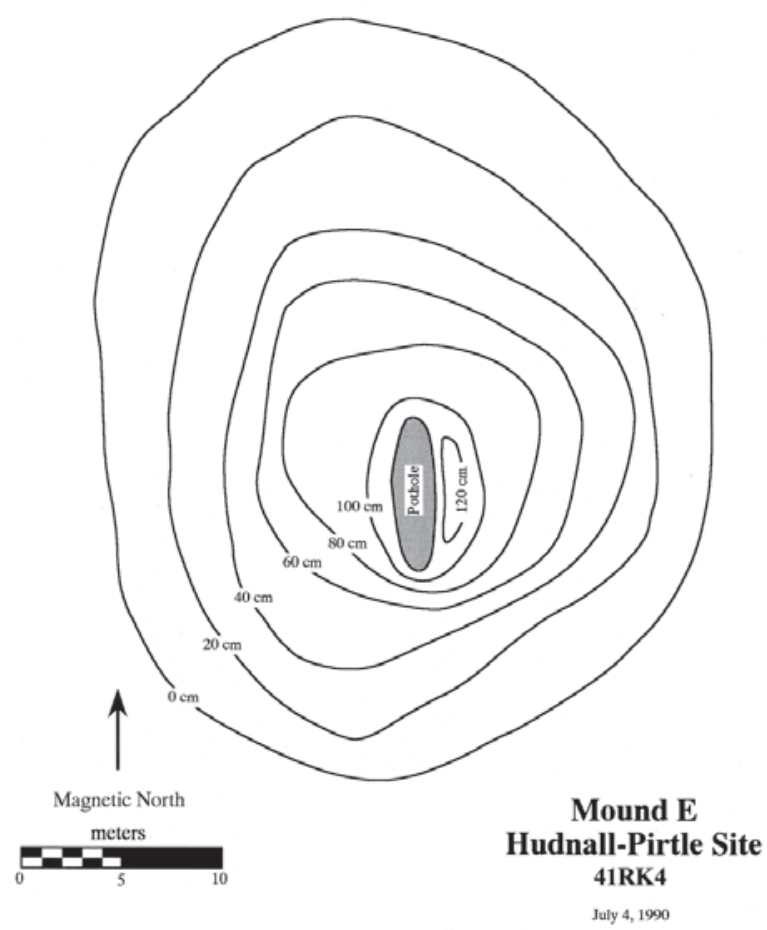

Figure 8. Contour map of Mound E.

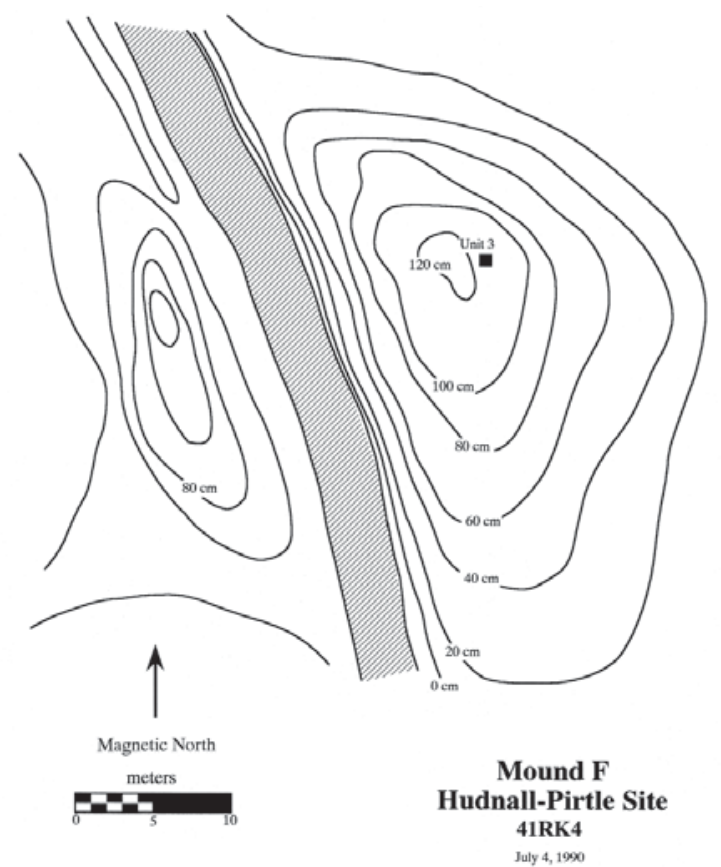

Figure 9. Contour map of Mound F; note Unit 3 location from 1989 excavations 


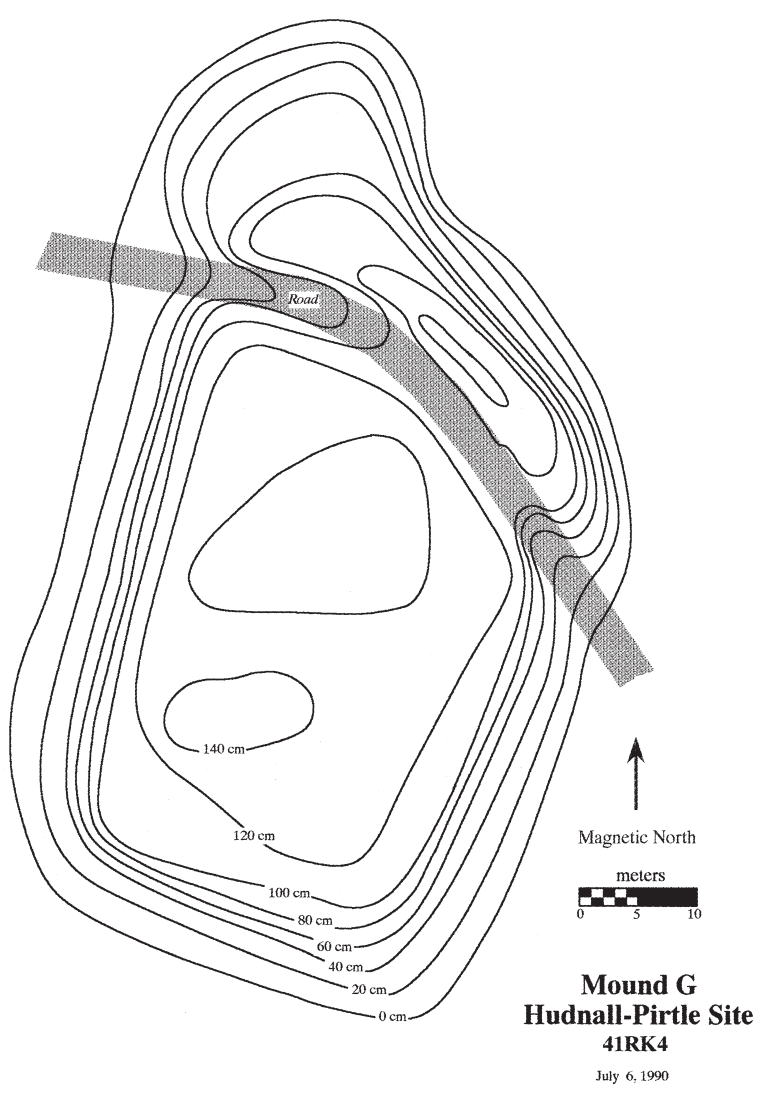

Figure 10. Contour map of Mound G

\section{November 13-17, 1989}

This work consisted of examining a trench, about 50 $\mathrm{cm}$ in width and $1.2 \mathrm{~m}$ in depth, that had been cut through the site to connect the new gas well to an older pipeline in the northwest of the site (see Figures 2-3). The agreement between The Archaeological Conservancy and Union Pacific, the oil exploration company doing the drilling, provided that the gasline trench would be dug by following the northern edge of a road through the site. Afterward, THC archeologists would walk the trench and examine and record any features that might be impacted. A $1 \times 1$ $\mathrm{m}$ unit was also started in the southwestern portion of the site during this time.

\section{July 16-27, 1990}

This work, the largest field effort conducted at the site, was performed to accomplish a number of tasks. The limited testing in the well pad during 1989 demonstrated that village debris existed in this area of the site. Block excavations were undertaken during 1990

(Figure 11) to obtain a larger sample of artifacts from the archeological deposits and recover information on the kinds of features that were present in different areas of the site.

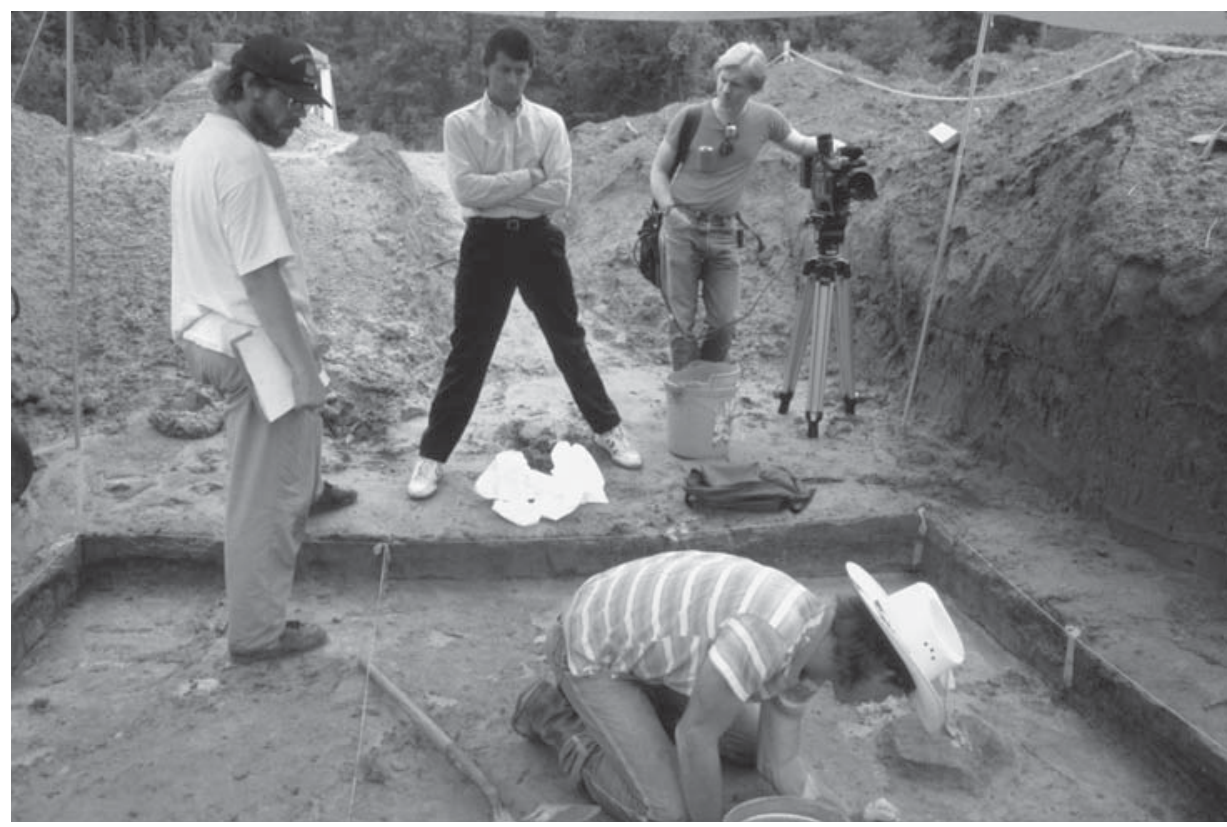

Figure 11. Excavations of the Well Pad area. 
During March 1989, a 1 x $1 \mathrm{~m}$ test pit had been started in the center of Mound F (see Figure 9) to determine if this low rise was a natural or human-made mound. The unit had been excavated to Level 13 (120-130 cm bs), where a mass of charcoal and dark-colored soil was encountered (Figure 12), likely the remains of a burned house. Excavation stopped at this level, but was resumed in 1990 .

Also during this time, two $1 \times 1 \mathrm{~m}$ units (Units 1 and 2) were excavated on the southern slope of the mound in the northwestern area of the site (see Figure 2) to determine if the mound was natural or cultural in character. The location of the mound away from the rest of the other mounds at Hudnall-Pirtle suggested that it might be a natural rise. The results of the test units were equivocal, necessitating additional test excavations to assess the mound. A $1 \times 2 \mathrm{~m}$ pit was then excavated on the mound's crest to see if cultural strata or other cultural features were present.

Since the Archaeological Conservancy owned a hundred acres of land, with the mounds themselves occupying about half that area (see Figure 2), shovel testing was conducted to determine which areas

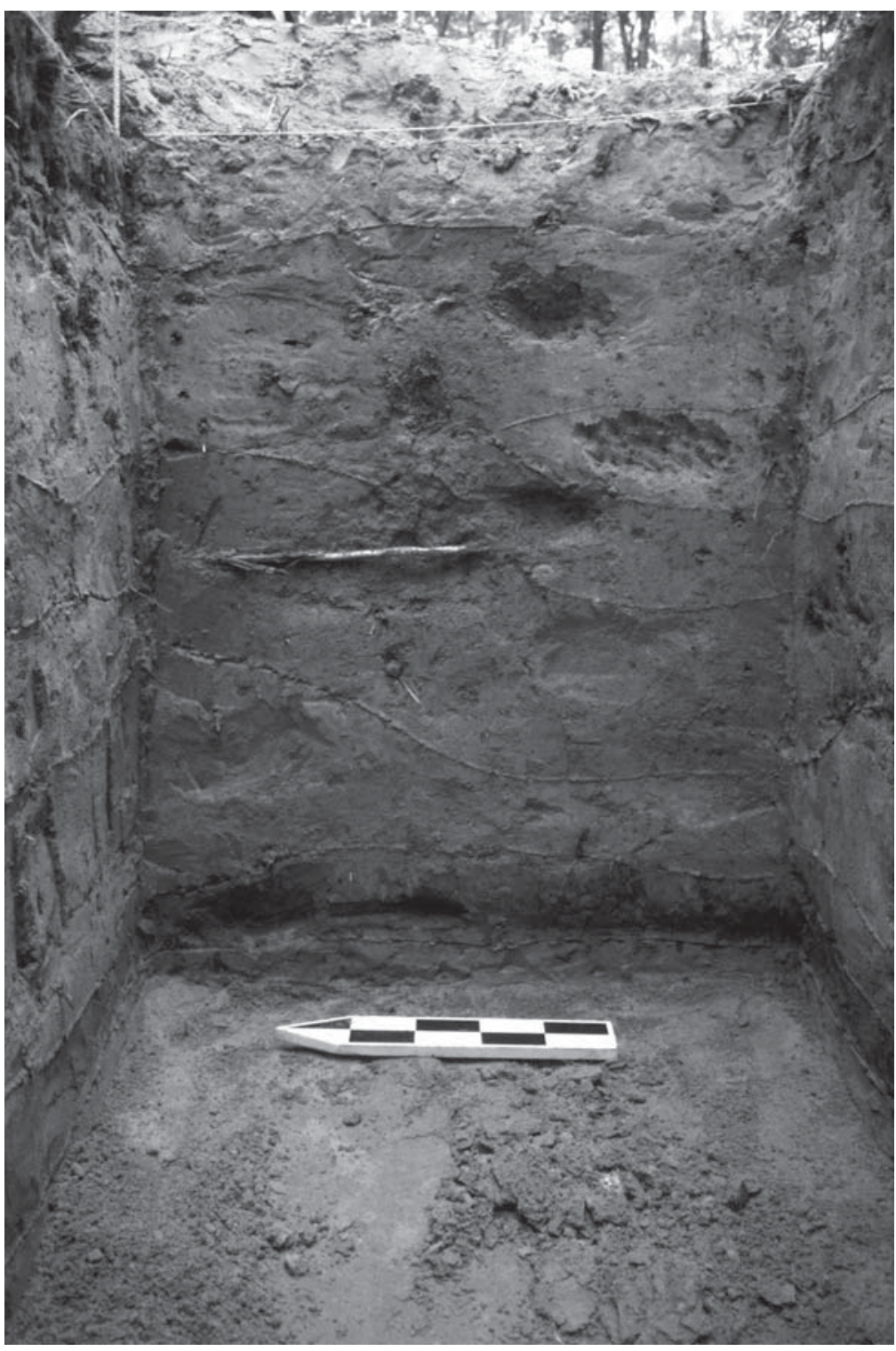
had village deposits and which did not. Figure 12. Profile of Mound F. Note the burned structure layer near the botThe purpose was to identify areas where tom of the profile.

timber could be harvested without impacting archeological deposits.

As discussed above, Calvin Jones of Longview had dug a network of trenches through Mound C in the 1960s but, according to his mother, did not find much. Jones had not filled his trenches. Our goal in 1990 was to clean a profile of the trench and record the mound stratigraphy. Soil would be screened during cleaning of the trench and any artifacts found were to be collected.

During a brief visit in the fall of 1989, a test pit had been started in the southwest corner of the site where village deposits were encountered. This pit was taken down only one level $(0-10 \mathrm{~cm})$. One goal of the 1990 fieldwork was to complete this unit and excavate several others to further sample the village deposits (Figure 13).

Other tasks in 1990 were to investigate small rises at the site to see if they were human-made mounds. We 


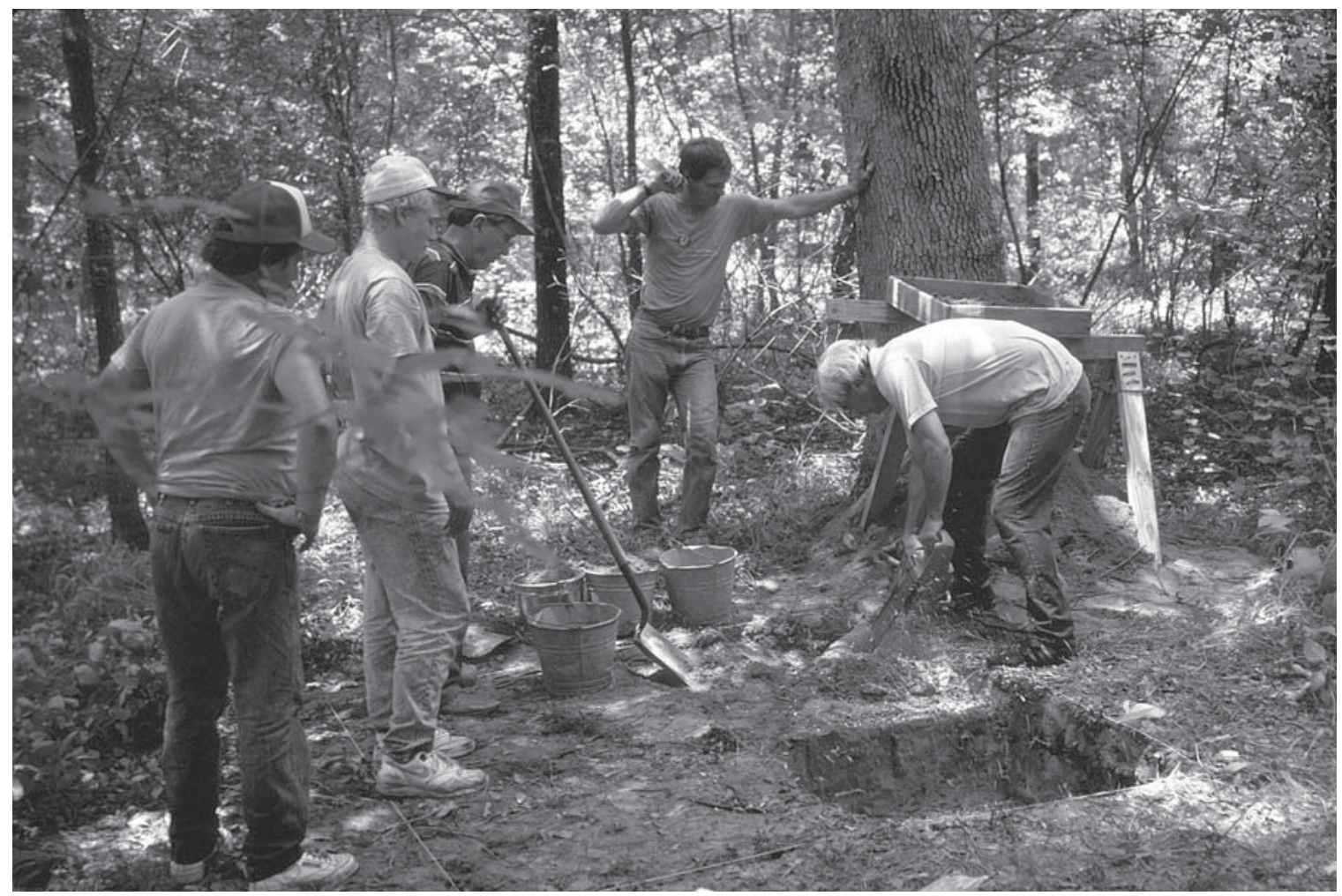

Figure 13. Excavation of a 1 x $1 \mathrm{~m}$ unit in the Southwest area.

investigated one slight rise on the southern edge of the well pad (Unit 10) where the field road cuts south, which had been largely destroyed by the road and the well pad. The remaining portions, however, exhibited the general shape of some of the small cultural mounds at the site. One goal in 1990 was to place units in the rise, look for stratigraphy and artifacts, and see if the rise represented a human-made mound. In other parts of the site, small rises are attached to one side of a mound. Another goal in 1990 was to investigate the small rise attached to Mound G (see Figure 10) to see if it was a cultural mound conjoined to the larger mound. It was possible that the rise represented bulldozer work associated with building a nearby road.

\section{August 25-27, 1990}

In the final phase of fieldwork at the Hudnall-Pirtle site, shovel testing that began in July of 1990 was completed, with shovel tests placed across much of the site (see Figure 2). These shovel tests showed that village archeological deposits cover a large area around the various mounds

\section{SITE AREAS USED FOR ANALYSIS}

Six areas of the Hudnall-Pirtle site have been delineated to assess the spatial distribution of artifacts. These areas are a subjective division of the site and largely represent locations where substantial field effort took place. The areas and units that comprise each are listed in Table 1. The shovel tests, are listed separately in Table 1, since they are distributed throughout much of the site and do not cluster in any area. 
Table 1. Excavation Units by Site Area.

\begin{tabular}{cc} 
Area & Units \\
\hline Mound A & 14 \\
Mound F & $3,11,24$ \\
Northwest & $1,2,7,19$ \\
Pipeline & $201,202,203,204,205,206$ \\
Southwest & $4-6,8,12,13,16,18,20-23$ \\
Shovel Tests & $1-70$ \\
Well Pad & $101-140$ \\
\hline
\end{tabular}

\section{ARCHEOLOGICAL DEPOSITS AT THE HUDNALL-PIRTLE SITE}

The archeological deposits at the Hudnall-Pirtle site occur in sandy loam to sand A- and E-horizon zones that occur on the T-1 landform, except for archeological deposits and features in Mound A and Mound F (see Table 1). The soils are part of the Laneville-Mattex soil association (Griffith 2001:23), with sandy Bienville soils on the alluvial terraces of the Sabine River.

In the northwest area, the archeological deposits occur in sandy loam to loamy sand deposits more than 150 $\mathrm{cm}$ in thickness (Figures 14 and 15). The lowermost E-horizon deposits reached in Unit 7 have thin $(<1 \mathrm{~mm})$ clay lamellae. Archeological materials were found throughout these sediments, but were concentrated in the upper $70 \mathrm{~cm}$.

Similar thick sandy deposits were uncovered in Unit 202 near Mound C (see Figure 10). In the plaza area between the mounds (see Figure 2), units excavated there uncovered almost no evidence of occupational debris, and what little there was occurred primarily below $50 \mathrm{~cm}$ bs. The sediments in the plaza (see Figure 14) consist of a thick plow zone overlying light-colored sands and sandy loams.

In the Southwest Village area, the sandy loam sediments with archeological materials are about $40-60 \mathrm{~cm}$ thick, with the shallowest deposits in the area of Unit 5/8/22/23 at the southern part of the area (see Figure 2). In Unit 5/8, the archeological deposits have an Ao-horizon overlying tan to red to white sandy loam and sand (Figure 16). In Units 18 and 20, however, the archeological deposits occur in dark grayish-brown to dark brownish-gray sandy loam sediment zones (features appear to originate from these deposits), and these overlie a mottled light gray sand and a yellowish-brown clay. The dark grayish-brown to dark brownish-gray sediments may be midden deposits. The units in this apparent midden deposit in the Southwest Village contain high densities of sherds (between 285-302 sherds per square meter) and some preserved animal bone (6.5-7 pieces per square meter). Outside the midden deposits in Units 4/8/22/23, sherd densities are only 68 per square meter, and the density of animal bone is 2 pieces per square meter.

Unit 10 was excavated in what was thought to be a aboriginal mound remnant just south of the well pad (see Figure 2). The excavations, however, demonstrated that it was not a mound, but instead an area of natural sandy loam sediments capped with overburden from well pad construction (Figure 17). The sandy loam sediments contained a low density of prehistoric ceramic sherds and lithic artifacts (see below). 
UNIT 17, NORTH WALL

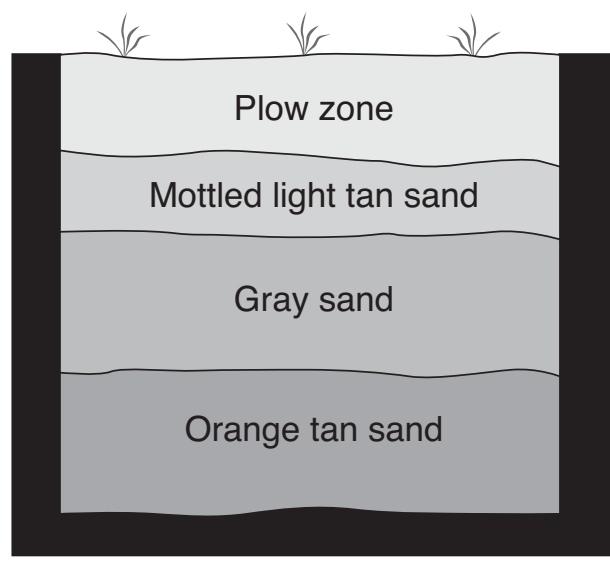

UNIT 2, EAST WALL

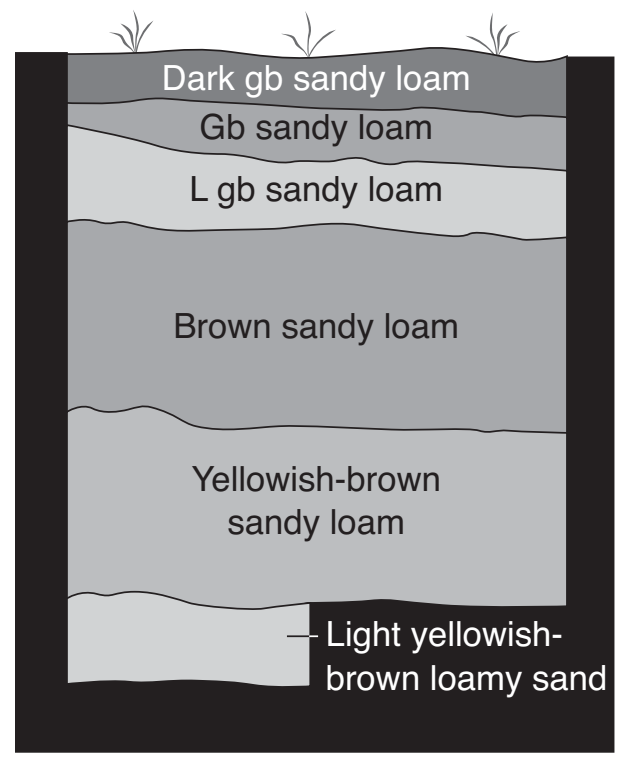

UNIT 202, NORTH WALL

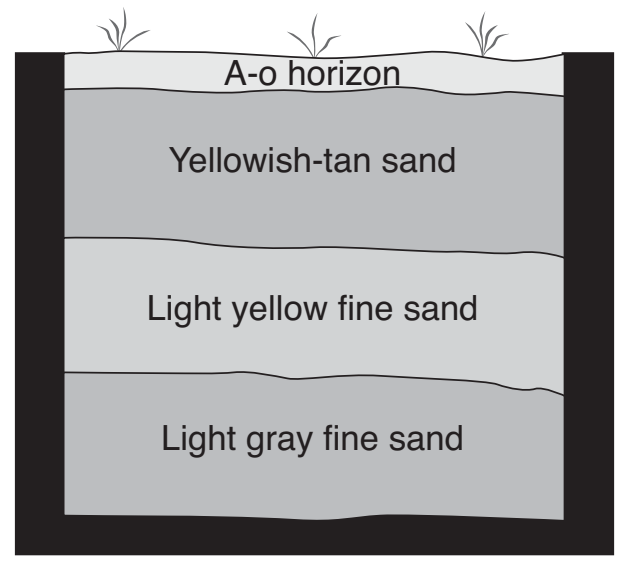

$30 \mathrm{~cm}$

UNIT 15, EAST WALL

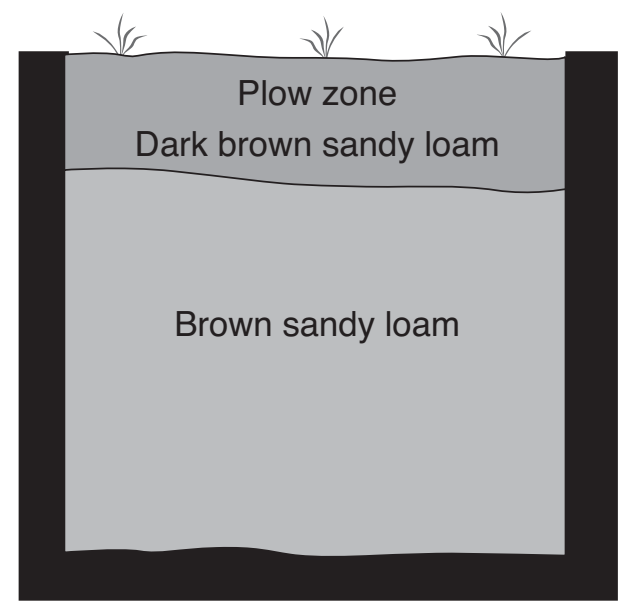

Figure 14. Profiles of units in the plaza (Units 15 and 17), the northwest area (Unit 2), and near Mound C (Unit 202). 


\section{UNIT 7 and 19, EAST WALL}

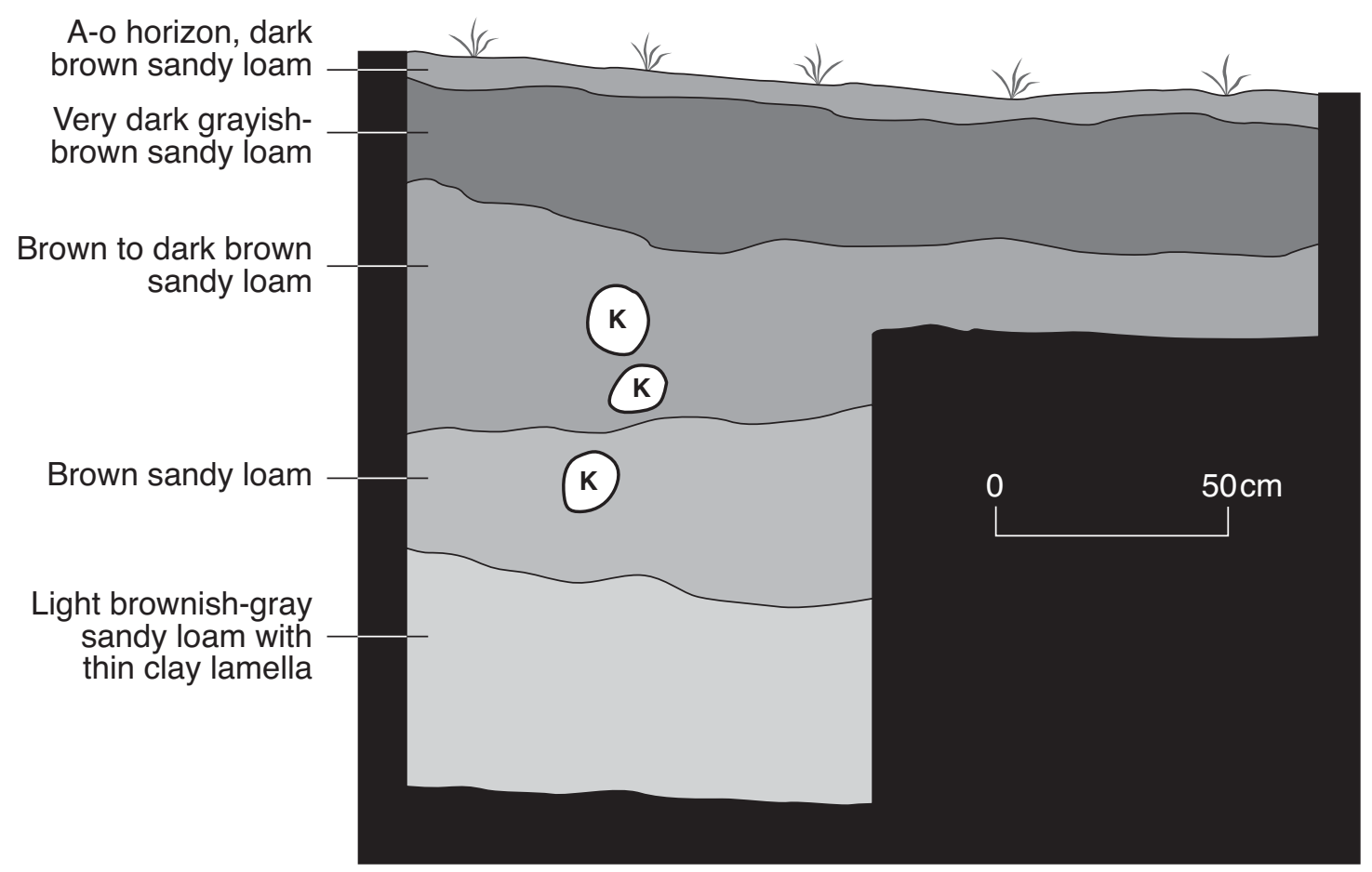

Figure 15. Unit 7 and 19, east wall profile, northwest area.

In the well pad area, the archeological deposits had been recently covered with a thick red clay cap from construction of the well pad atop the deposits. Below the clay cap was a dark brown sandy loam plow zone and A-E-horizon sandy loams and sand that ranged from brown to yellowish-brown in color (Figure 18).

The majority of the archeological materials were recovered from the plow zone and the A1 brown sandy loam sediments. These materials were much more common in the Well Pad north units than in those in the Well Pad south units, especially the lithic debris (50 pieces per square meter vs. 14 pieces per square meter) and ceramic sherds ( 86 sherds per square meter vs. 76 sherds per square meter). Animal bone was also better represented in the north units $(n=26)$ compared to the Well Pad south units $(n=6)$, as was the density of features (see below). The Well Pad north area excavations appear to have been placed in a well-preserved domestic habitation area.

\section{Mound F Stratigraphy}

Initially a single $1 \times 1 \mathrm{~m}$ unit was excavated in the approximate center of the mound. This unit (labeled Unit 3 ) encountered five soil zones (see Figure 19). Two additional units were excavated to further investigate the mound, one to the east (Unit 11) and another to the west (Unit 24) of Unit 3. From this additional work, a sixth zone (labeled \#1 on Figure 19) was encountered consisting of the normal sub-mound or natural soil profile under the mound.

The sequence of events that led to mound construction began with the building of a structure on the original ground surface. This structure was burned, based on calibrated radiocarbon mid-ranges (see Feature 12 description below), 

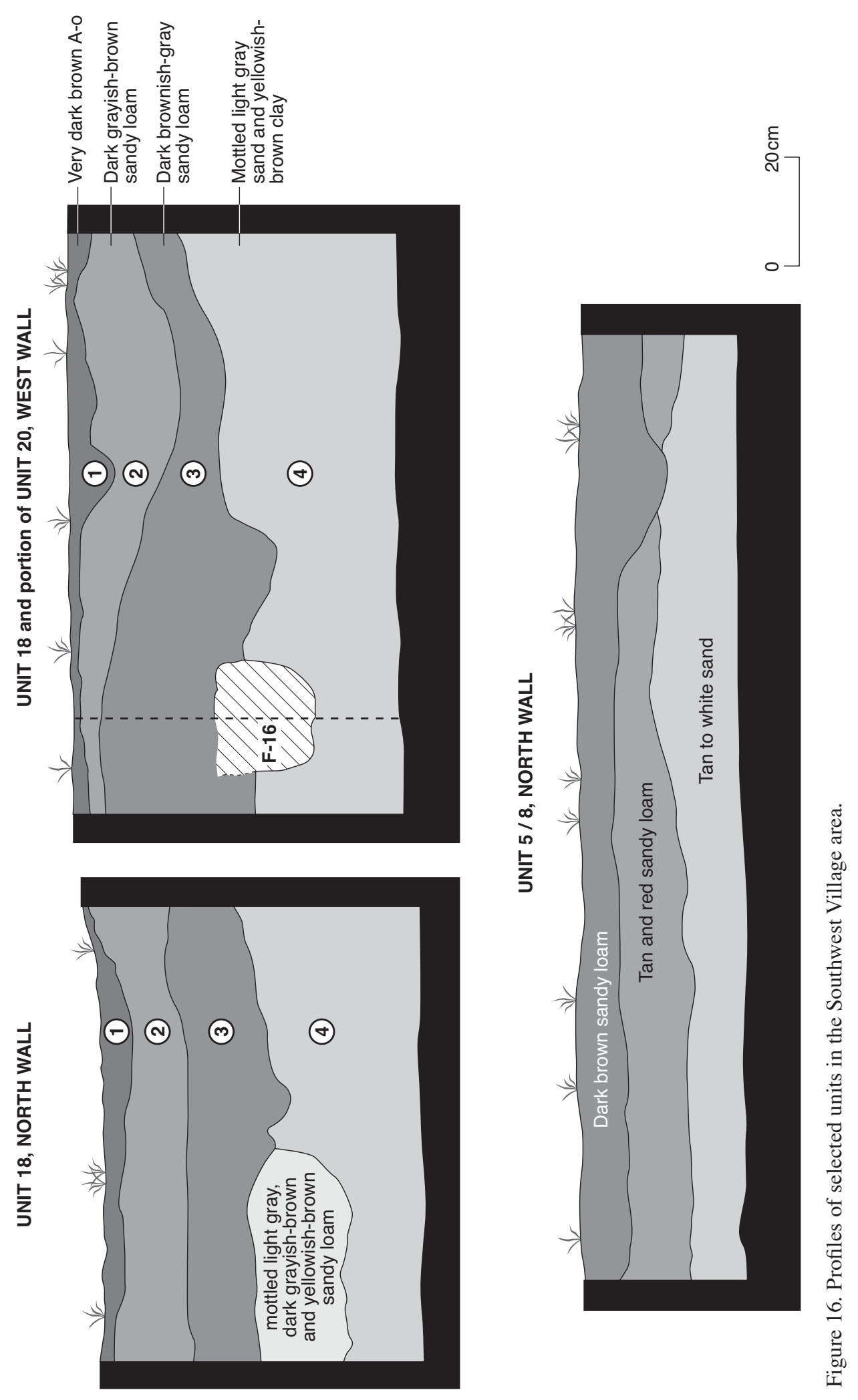
at some point between A.D. 10451048. This created a dark brown sandy loam zone (labeled \#2 on Figure 19) from 8 to $15 \mathrm{~cm}$ thick with large quantities of charcoal; this zone was also given the designation as Feature 12. Next, a yellow clay soil was brought in and placed over the remains of the structure to form Zone \#3, measuring between 35 and $60 \mathrm{~cm}$ in thickness. This activity occurred while the charred remains of the structure were still hot, as seen by orange oxidized soil in areas where the fill contacted the structure remains. Over this, three additional layers of soil were added: Zone \#4 is a light red color sandy clay between 20 and $62 \mathrm{~cm}$ thick; Zone \#5 is an orange sandy clay with a maximum thickness of $50 \mathrm{~cm}$ that lenses out at the juncture of Units 3 and 11; and Zone \#6 which is a organically stained sandy loam that is similar to the soil found at the surface across much of the site.

In plan view, Feature 12 extended

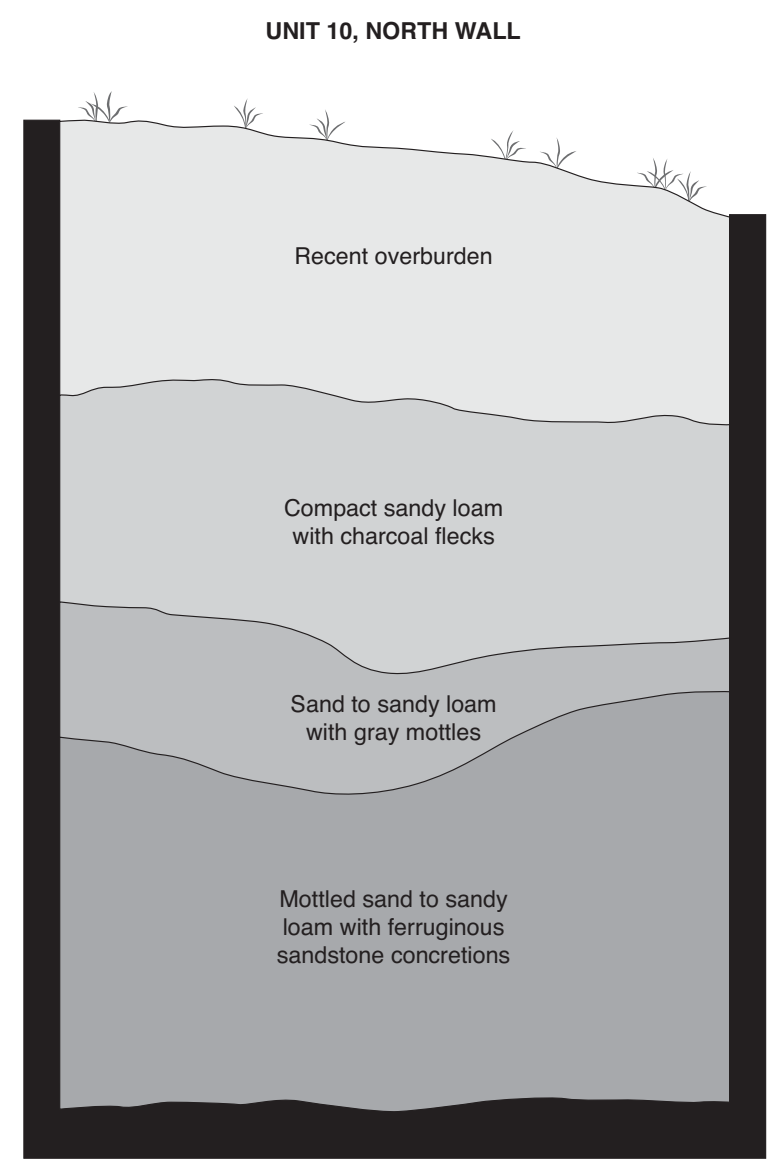

Figure 17. Profile of Unit 10. across all of Unit 24, most of Unit 3, and over about one-third of Unit 11. In Units 3 and 11, Feature 12 forms an arc that apparently corresponds with the exterior wall of the structure capped by the mound. One definite (labeled Feature 10) and three possible post holes were found along the arc and likely represent posts from the initial construction and later rebuilding of the structure. Few artifacts were found during excavation, and this plus the building of a mound over Feature 12 argues for a specialized, non-domiciliary use for the structure. No evidence of other structures at higher levels in the mound fill was observed. However, further field investigation of Mound F is necessary to confirm this preliminary observation.

\section{Features at the Hudnall-Pirtle Site (41RK4), 1990 Excavations}

A variety of cultural features were documented in the 1990 excavations at the Hudnall-Pirtle site (41RK4), including post hole stains and pit features. The pit features probably were used for storage, cooking activities, and eventually for trash disposal. Included among the 25 features was remnants of a burned house floor in the Mound F excavations. Most of the features were found in the Well Pad North and Southwest Village areas (see Figure 2). Radiocarbon samples were obtained on charred plant remains from several of the Hudnall-Pirtle features, and the calibrated age ranges (at 2 sigma) on these from the habitation areas and Mound $\mathrm{F}$ range from AD 980-1265, consistent with an Early Caddoan period occupation, and from AD 1410-1950 in Feature 17 in the Southwest Village (see below). 


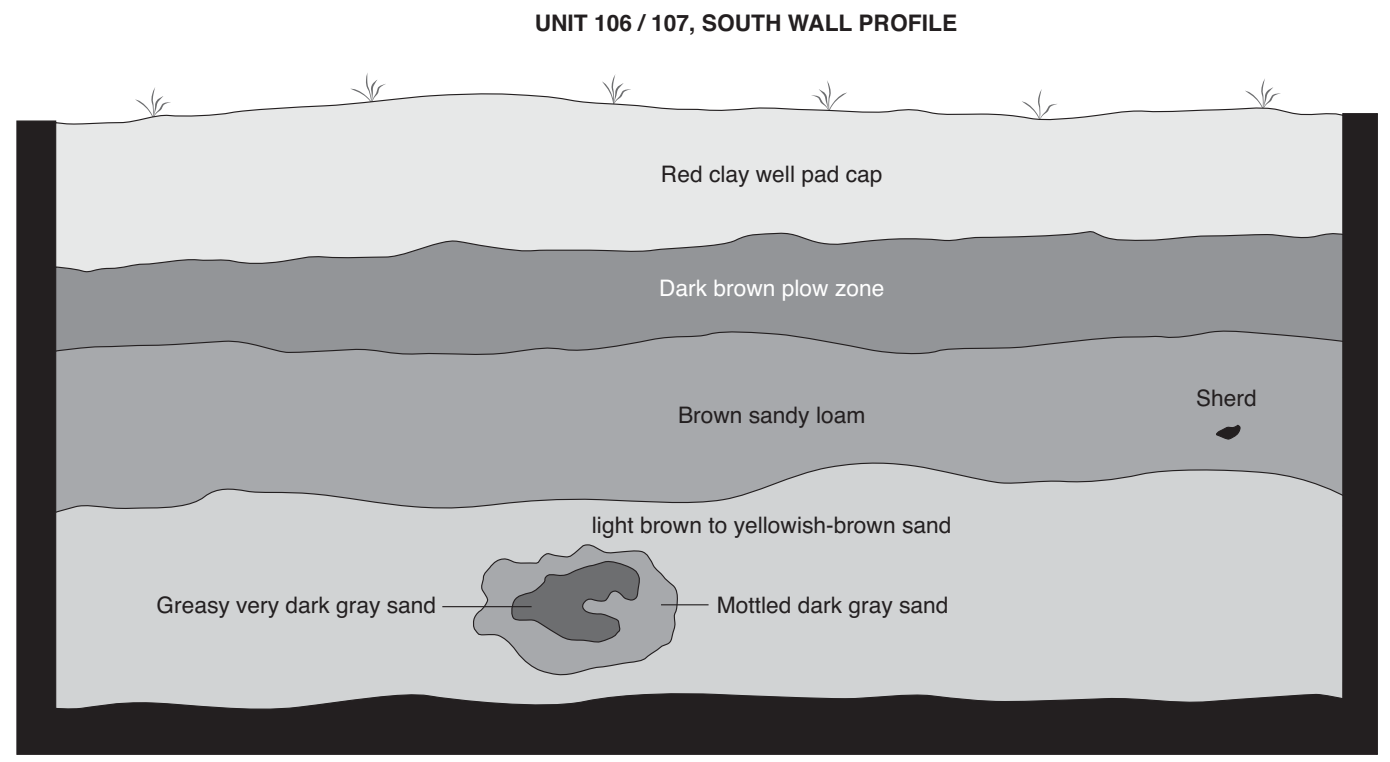

Figure 18. Profile of Unit 106 and 107, south wall.

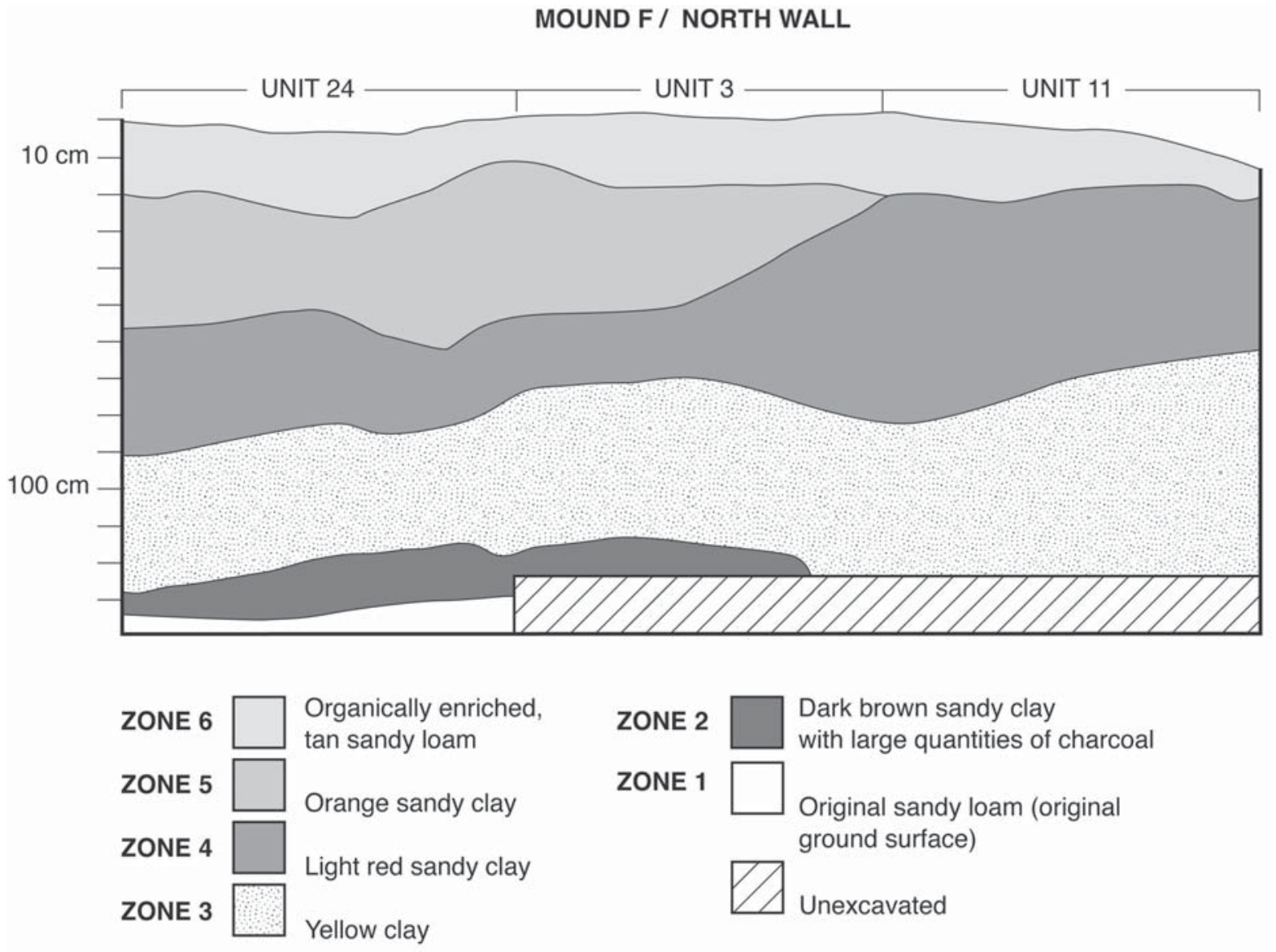

Figure 19. Mound F profile, Hudnall-Pirtle site. 


\section{Well Pad North}

Fourteen cultural features were excavated in the $2 \times 12 \mathrm{~m}$ trench (Figure 20) in this part of the Hudnall-Pirtle site (see Figure 2). The features comprise several post holes and a variety of pits of different sizes and contents. One to 20 liter flotation samples were collected from all but one feature (Feature 110) in the Well Pad North area. In general, the features are concentrated at the eastern end of the trench, and most range in depth from 45 to $78 \mathrm{~cm}$ bsd (below the surface datum); two pit features extended to 90 and $92 \mathrm{~cm} \mathrm{bsd}$.

\section{Feature 103}

Defined at $51 \mathrm{~cm}$ bsd, Feature 103 is a $48 \mathrm{~cm}$ diameter stain with a dark brown-black sandy loam fill. In profile, it is $23 \mathrm{~cm}$ thick (74 cm bsd) with straight sides and a flat bottom. Contents: 1 Form 11 arrowpoint; 5 lithic debris; 1 incised sherd, and $0.21 \mathrm{~g}$ of charred plant remains. These remains include wood charcoal, cane stem, thick hickory nutshell, acorn shell, and maize cupules and glumes.

\section{Feature 104}

This is a well-preserved pit with undercut sides and two fill zones (Figure 21); it is immediately adjacent to Feature 111, another pit with undercut sides, and a shallow stain incorporates both features. Feature 104 is about $40 \mathrm{~cm}$ in diameter at the surface but is undercut to form a pit $60 \mathrm{~cm}$ in diameter about $80 \mathrm{~cm}$ bsd. It is $36 \mathrm{~cm}$ thick (56-92 cm bsd), with rounded sides and a flat bottom. The upper fill $(16 \mathrm{~cm}$ thick) is a dark brown sandy loam with charcoal and bone flecks, while the lower fill $(20 \mathrm{~cm})$ in the undercut portion of the pit has a moist, black, greasy, sandy loam indicative of high organic content; all the charred maize is from the upper fill, while the lower fill is dominated by wood charcoal, thick hickory nutshell, and acorn shell and meat.

A radiocarbon sample of $4.7 \mathrm{~g}$ of charred maize (C13/C12 value of $-9.4 \mathrm{o} / \mathrm{oo})$ was submitted for dating, and the 2 sigma calibrated age range is AD 980-1235. The one sigma age range of the sample is AD 1010-1175, with a calibrated intercept of AD 1040 (Beta-129983) (see Appendix 1).

Contents: 12 pieces of animal bone in the upper fill (including one deer metapodial), and 2 animal bones in the lower fill (see Figure 21); 1 core fragment; 18 lithic debris in flotation sample, and 2 lithic debris in upper fill, 2 in lower fill. Charred plant remains in the feature fill include $7.50 \mathrm{~g}$ of wood charcoal, thick hickory nutshell, acorn shell and meat, and maize kernels, cupules, and glumes. This feature also had 162 sherds (137 sherdlets), 22 plain sherds, and three decorated sherds ( 1 incised, 2 engraved)

\section{Feature 105}

Feature 105 is a small pit exposed in the north wall profile of the trench, and at $51 \mathrm{~cm}$ bsd it extends only about $17 \mathrm{~cm}$ into Unit 113 (see Figure 20). Based on the general oblong shape of the feature, it is probably about 30$35 \mathrm{~cm}$ in diameter. The pit is $11 \mathrm{~cm}$ in thickness, with rounded sides and bottom, and the feature fill consists of a dark brown to black sandy loam with charcoal flecks. Contents: 2 lithic debris and 1 plain sherd. 
WELL PAD NORTH

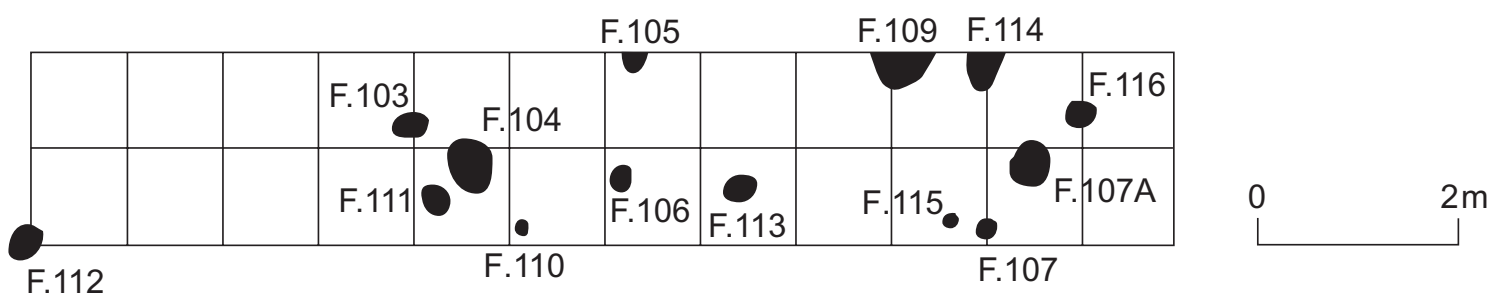

WELL PAD SOUTH F.101

F.108

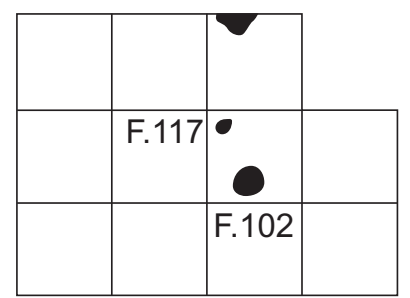

Figure 20. Distribution of features in the Well Pad excavations.
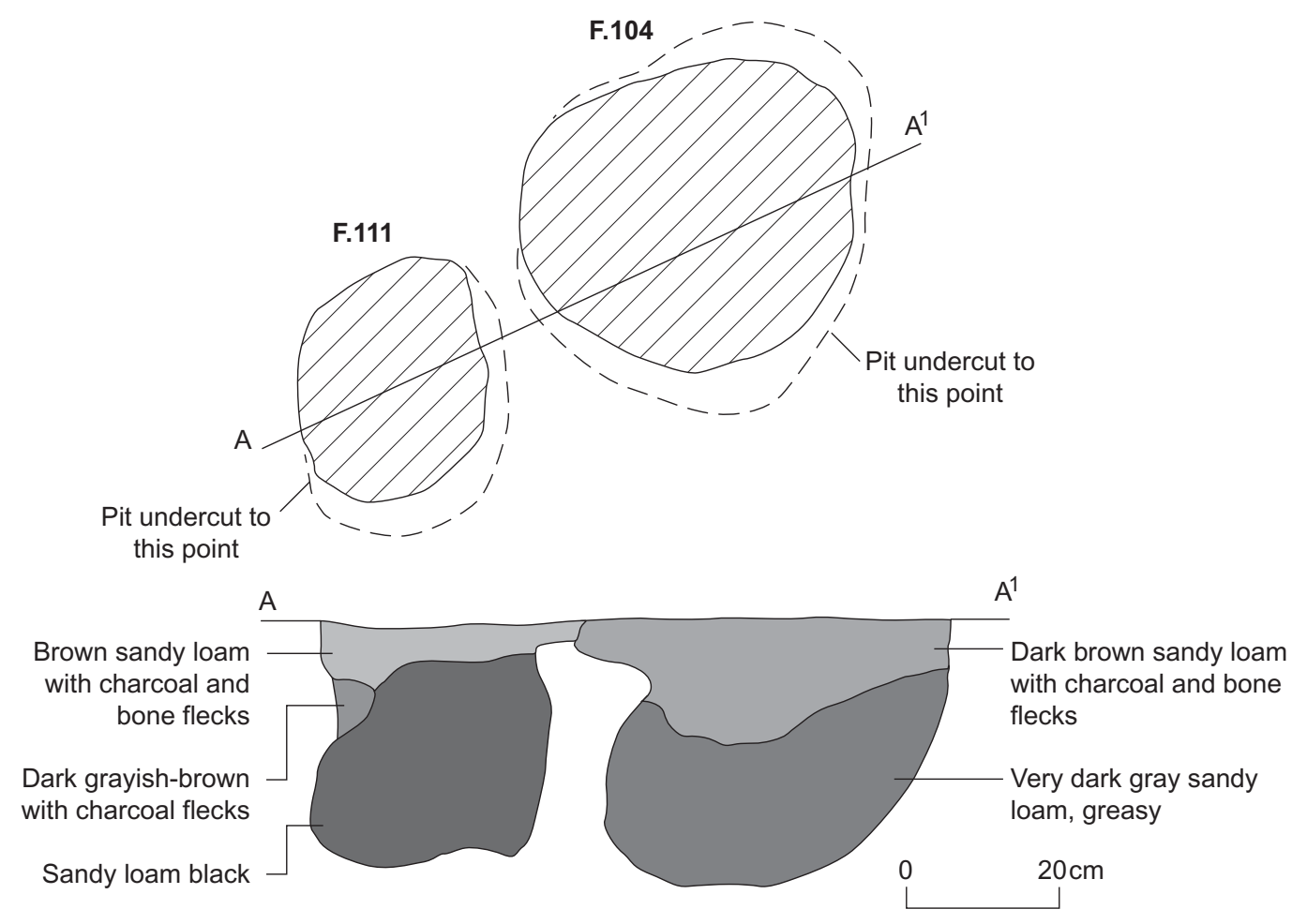

Figure 21. Plan and profile of Features 104 and 111. 


\section{Feature 106}

The feature represents a pit with undercut sides and a distinctive black, greasy fill (Figure 22). Feature 106, about $35 \mathrm{~cm}$ in diameter at the pit opening, was exposed at $56 \mathrm{~cm}$ bsd, and it is $22 \mathrm{~cm}$ thick. Its maximum diameter is $40 \mathrm{~cm}$ near the base of the pit. The pit has two fill zones: the upper fill (ca. $7 \mathrm{~cm}$ thick) is a dark brown to black sandy loam with a greasy texture, while the lower fill $(\mathrm{ca} .15 \mathrm{~cm})$ is a black, greasy, sandy loam with a few dark brown and brown mottles. Contents: 3 lithic debris; 1 plain sherd; $2.47 \mathrm{~g}$ of charred plant remains, including wood charcoal, acorn shell, and maize kernels, cupules, and glumes.

\section{Feature 107}

Feature 107 is an amorphous dark brown sandy loam stain (with tiny charcoal flecks) defined at $45 \mathrm{~cm}$ bsd that ranges from 5-21 cm in thickness; it thickens in a grid east direction. At its deepest, the feature is about 20 $\mathrm{cm}$ in diameter, with rounded sides and a flat bottom, and probably represents a post hole stain. The shallower stain to the west may represent the disturbance caused by setting the post in the ground. An arrow point tip was recovered $5 \mathrm{~cm}$ north of the feature. Contents: 2 burned animal bones and 7 plain body sherds.

\section{Feature 107A}

This feature is about a $70 \mathrm{~cm}$ diameter pit that extends from $50-69 \mathrm{~cm}$ bsd. The pit is undercut in profile, with straight sides and a rounded bottom, with two different fills (see Figure 22). The uppermost fill (about $8 \mathrm{~cm}$ in thickness) contains the majority of the cultural materials, and it is a dark brown sandy loam with charcoal streaks. The lower fill $(11 \mathrm{~cm}$ in thickness) is within the undercut portion of the pit. It is a mottled dark brown sandy loam, no charcoal streaks, and the fill has an extremely high organic content. Several other features in Well Pad North have this distinctive organic matrix. Contents: 2 pieces of animal bone; 11 lithic debris.

\section{Feature 109}

Feature 109 appears to be comprised of two different features: a shallow basin-shaped pit between ca. 46-58 $\mathrm{cm}$ bsd, and a post hole at one side of the pit that extends to $73 \mathrm{~cm}$ bsd (see Figure 22). The pit is exposed in the floor of the trench, as well as in the trench profile, and covers a 55 x $30 \mathrm{~cm}$ area. Its matrix is a dark brown sandy loam with gray mottles and charcoal flecks. The probable post is about $20 \mathrm{~cm}$ in diameter, and has a similar fill, except for manganese and hematite concretions near the base of the post hole where it terminates at the iron-rich B-horizon. Contents: 1 piece of animal bone; 8 lithic debris; 4 sherds, including 2 plain body sherds and 2 free punctated sherds; $0.06 \mathrm{~g}$ of charred plant remains, including wood charcoal and thick hickory nutshell.

\section{Feature 110}

This is a post hole stain exposed from $50-58 \mathrm{~cm}$ bsd. It is $20 \mathrm{~cm}$ in diameter, has a dark brown sandy loam fill with charcoal flecks, with rounded sides and a flat bottom (see Figure 22). The posthole may overlie another feature, albeit one that is poorly defined, since a major concentration of sherds was exposed about $90 \mathrm{~cm}$ bsd, 

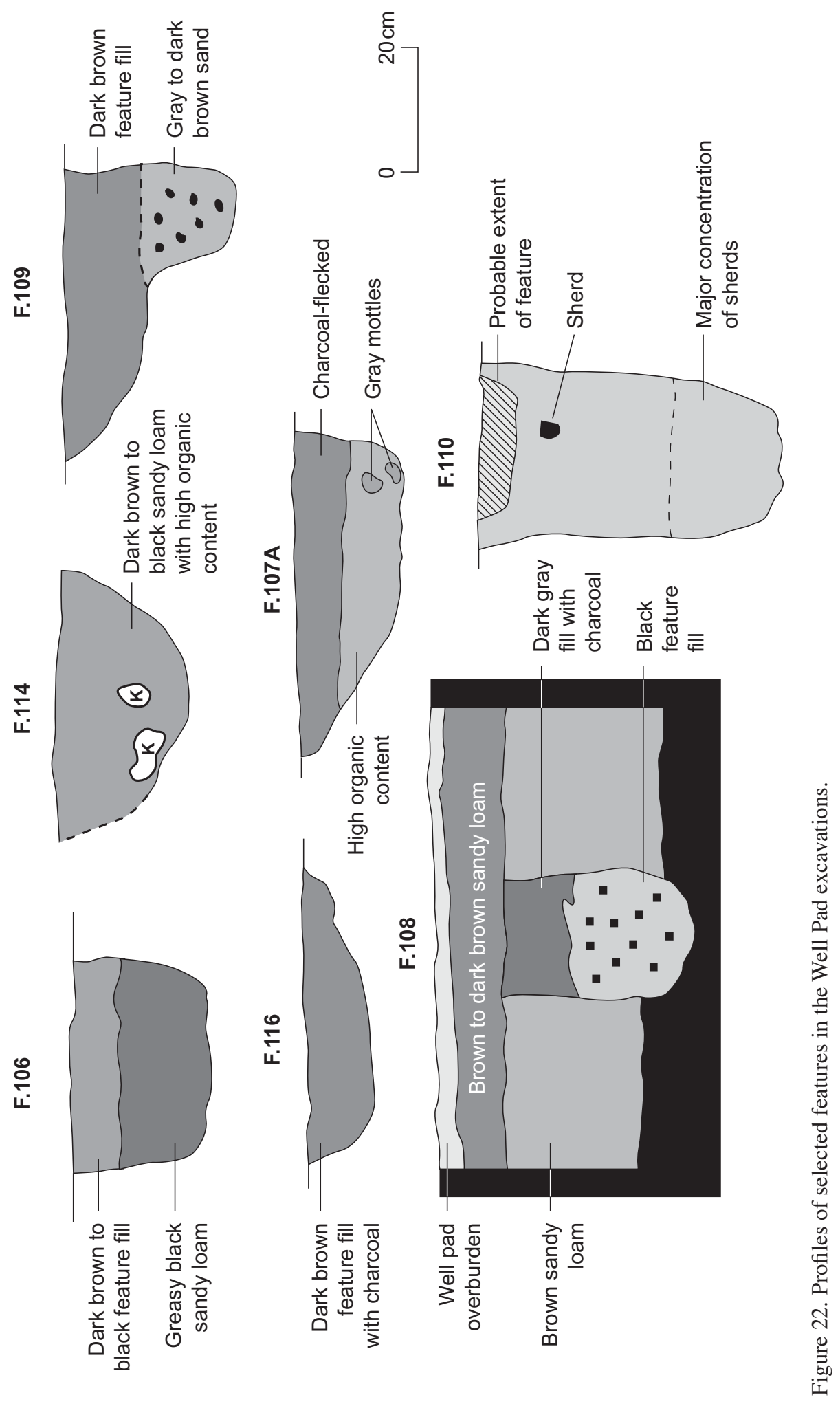
directly below the shallow post hole. Feature 110 contents: 1 multiple-platform flake core, 1 core fragment; 2 lithic debris, and 28 sherds. Twenty of the sherds are plain, and eight are decorated ( 2 incised, 4 free punctate, 1 Coles Creek Incised, var. Coles Creek, and one with circular punctates with linear incised lines).

\section{Feature 111}

At the level of exposure ( $56 \mathrm{~cm}$ bsd), Feature 111 is a $30 \mathrm{~cm}$ diameter pit, but it is undercut to about $40 \mathrm{~cm}$ in diameter midway down the pit basin. The pit is $34 \mathrm{~cm}$ thick. It has an undulating bottom with concave sides, and the pit contains three distinct fill zones (see Figure 21).

The uppermost fill (ca. $8 \mathrm{~cm}$ thick) is a dark brown sandy loam with charcoal flecks and small amounts of burned bone, and the second fill is a small wedge (about $7 \mathrm{~cm}$ thick) at the western part of the pit that is a slightly darker brown sandy loam with charcoal flecks. The third and thickest fill $(\mathrm{ca} .28 \mathrm{~cm})$ is a black sandy loam.

A radiocarbon sample of $7.3 \mathrm{~g}$ of charred maize $(\mathrm{C} 13 / \mathrm{C} 12$ value of $-10.1 \mathrm{o} / \mathrm{oo})$ from the upper feature fill yielded a 2 sigma calibrated age of AD 1015-1265, with a calibrated intercept of AD 1170. The 1 sigma age range is AD 1040-1220 (Beta-129984).

Contents: 1 piece of animal bone from the third and lowermost fill; 15 lithic debris; 3 plain body sherds, 16.18 $\mathrm{g}$ of charred plant remains. The plant remains include one charred seed, wood charcoal, thick hickory nutshell, acorn shell, and $14.59 \mathrm{~g}$ of maize kernels, cupules, and glumes.

\section{Feature 112}

Feature 112 is a post hole that was exposed in profile (from $48-59 \mathrm{~cm}$ bsd) at the far southwest corner of the $2 \times 12 \mathrm{~m}$ trench (see Figure 20). It appears as a dark brown sandy loam stain (estimated $20 \mathrm{~cm}$ diameter) with charcoal flecks; charcoal is most frequent along the flat bottom of the stain. The feature also has straight sides. Contents: 3 lithic debris, 2 plain body sherds, and $3.64 \mathrm{~g}$ of charred plant remains. These remains include wood charcoal, bark, and $0.59 \mathrm{~g}$ of maize cupules and glumes.

\section{Feature 113}

This is a thin (51-56 cm bsd) and amorphous stain with a charcoal-streaked dark brown to gray sandy loam fill. The oblong stain is about $45 \mathrm{~cm}$ in diameter, and in profile has rounded sides and a flat bottom. A small sherd cluster (at $55 \mathrm{~cm} \mathrm{bsd}$ ) is about $40 \mathrm{~cm}$ to the southwest of Feature 113. Contents: 1 lithic debris.

\section{Feature 114}

This feature is exposed between 52-74 cm bsd along the north wall of the trench, and it extends $35 \mathrm{~cm}$ into Units 119 and 121. It is an oblong stain, estimated at $50 \mathrm{~cm}$ in diameter, with rounded sides and a rounded bottom (see Figure 22). The pit fill is a dark brown-black sandy loam with charcoal, burned bone, and it has a high organic

content. Several small rodent krotovina are present near the base of the pit, and it has also been disturbed by a tree root in Unit 119. Contents: 3 pieces of burned animal bone; 12 lithic debris.; and 5 plain body sherds. 


\section{Feature 115}

Feature 115 is a post hole stain exposed at $52 \mathrm{~cm}$ bsd in Unit 118 . It is roughly $18 \mathrm{~cm}$ in diameter, has gently rounded sides and a flat bottom; the feature fill is a dark brown sandy loam. The post hole bottomed out at 57 $\mathrm{cm}$ bsd, indicating only a small remnant portion of the feature was preserved below the scraped level of the trench. Contents: 2 lithic debris and $0.10 \mathrm{~g}$ of wood charcoal and thick hickory nutshell.

\section{Feature 116}

Exposed at $50 \mathrm{~cm}$ bsd, this feature is a small $(30 \mathrm{~cm}$ in diameter), shallow $(11 \mathrm{~cm})$ pit with a dark brown sandy loam fill with charcoal streaks; one quadrant is only about $5 \mathrm{~cm}$ in thickness. It has rounded sides with a relatively flat bottom (see Figure 22). Feature 107A is about $60 \mathrm{~cm}$ south of this feature (see Figure 20). Contents: 1 lithic debris, 1 incised sherd, 1 sherdlet, and 1 plain sherd, and $0.10 \mathrm{~g}$ of wood charcoal, thick hickory nutshell, and acorn shell.

\section{Well Pad South}

Three features were recorded in the 3 x 3 m block on the Well Pad South area (Units 124-132): Features 102, 108, and 117 (see Figure 20). Two to seven liter flotation samples were collected from each of these features. At the base of level 3, a large and amorphous charcoal-mottled stain $(110 \times 160 \mathrm{~cm}$ in length and width) was also noted between features 108 and 117 at the northern end of the block (in Units 125, 126, 128, and 129), but it proved to be a natural soil disturbance rather than a cultural feature.

\section{Feature 102 (Unit 129)}

Extending from 39-47 cm bsd, Feature 102 is a $19 \mathrm{~cm}$ diameter stain of post hole size. In profile, the stain has straight walls and a flat bottom. The matrix is a black (10YR 2/1) sandy loam without charcoal flecks; the surrounding matrix is a mottled dark brown-gray sandy loam A-horizon. A small root runs adjacent to the feature, and root disturbances were apparent at the upper depths of the stain. Contents: 2 lithic debris and $0.11 \mathrm{~g}$ of charred plant remains. This includes wood charcoal and cane stems.

\section{Feature 108 (Unit 126)}

This feature was exposed in the north wall of the block. Feature 108 is a $22 \mathrm{~cm}$ diameter wide stain with rounded sides and a flat bottom, and we presume it is a large post hole. It originates at the contact between soil zones I and II (at $42 \mathrm{~cm} \mathrm{bsd}$ ), and extended to $62 \mathrm{~cm}$ bsd. Matrix in the post hole ranged from a dark gray sandy loam with charcoal flecks at the top of the feature to a black sandy loam at the bottom (see Figure 22).

\section{Feature 117 (Unit 129)}

Feature 117 is a $20 \mathrm{~cm}$ diameter stain that is $43-80 \mathrm{~cm}$ in depth bsd. Its slightly rounded sides and flat bottom suggest it is also a post hole. The post hole fill is a dark brown to gray sandy loam without charcoal flecks. Contents: 1 lithic debris and $0.09 \mathrm{~g}$ of wood charcoal. 


\section{Feature 101 (between Well Pad North and South)}

This feature was exposed in a backhoe trench about 56-60 cm bsd and $1.4 \mathrm{~m}$ northeast of Feature 108 (see Figure 20). It consists of a circular stain (ca. $40 \mathrm{~cm}$ in diameter) with a charcoal-streaked and mottled brown-gray sandy loam fill. In profile, the stain has straight sides and a relatively flat bottom. The maximum depth of the feature is only $4 \mathrm{~cm}$, suggesting that most of the feature had been removed by scraping before it was identified. If it is a post, it may represent a large interior support rather than one of the smaller posts $(\mathrm{ca} .20 \mathrm{~cm}$ in diameter) forming the exterior walls of a structure. Contents: $0.62 \mathrm{~g}$ of charred plant remains, including wood charcoal and thick hickory nutshell.

\section{Southwest Village Area}

Six cultural features, and several possible post hole stains (not assigned feature numbers, however, or recognized in the field as such) were excavated in the Southwest Village area. Features were found in each of the dispersed $2 \times 2 \mathrm{~m}$ unit excavations, suggesting that features are quite common throughout this part of the site. Flotation samples (3-8 liters in size) were collected from features 13, 14, 16, and 17 in this village area.

\section{Feature 11}

This post hole was recorded between $40-50+\mathrm{cm}$ bs in Unit 13. It is about $20 \mathrm{~cm}$ in diameter, with a black sandy loam fill. Feature 11 was exposed near the base of the A-horizon, but it was not cross-sectioned or profiled before the unit was back-filled.

\section{Feature 13}

Feature 13 is a shallow pit (40-52 cm bs) in units 4 and 18 in the village area. The circular feature is ca. 50 $\mathrm{cm}$ in diameter, with a dark gray-black sandy loam fill that has charcoal flecks. The top of a possible post hole was detected at $40 \mathrm{~cm}$ bs only $10 \mathrm{~cm}$ west of Feature 13. Contents: $3.27 \mathrm{~g}$ of charred plant remains, including wood charcoal, thick hickory nutshell, acorn shell, and a single maize kernel; 11 plain body sherds, 3 fingernail punctated sherds with horizontal incised lines; 1 hematite rock.

\section{Feature 14}

Exposed in Unit 16, Feature 14 is a small pit, with rounded sides and bottom, that contains charcoal and bone. It is about $35 \mathrm{~cm}$ in diameter, and extends from $40-69 \mathrm{~cm}$ bs. Feature matrix is a black sandy loam. Contents: 41 pieces of animal bone, including two identifiable deer elements; 1 battered core; 14 lithic debris; 5 firecracked rocks; 14 plain body sherds, and 2 fingernail punctated sherds with horizontal incised lines; $13.45 \mathrm{~g}$ of charred plant remains, including wood charcoal, pitch, thick hickory nutshell, acorn shell and meat, maize kernels, cupules, and glumes, and several charred seeds. Three possible posthole stains were also detected in Unit 16; these were noted at $40 \mathrm{~cm}$ bs, the same depth as the top of the pit. 


\section{Feature 15}

Feature 15 is an irregularly-shaped pit that extends from $33 \mathrm{~cm}$ bs to a maximum of $55 \mathrm{~cm}$ bs along the eastern side of the pit; it is only $9 \mathrm{~cm}$ thick in the western half of the feature. The pit is ca. $68 \mathrm{x} 40 \mathrm{~cm}$ in size, and has a dark brown sandy loam matrix with charcoal flecking. Contents: 1 lithic debris.

\section{Feature 16}

In profile, this feature appears to be a post hole about $23 \mathrm{~cm}$ in diameter (see Figure 16), which is within the range for post holes along structure walls. It has rounded sides and a flat bottom, and extends from $30-52 \mathrm{~cm}$ bs. The plan map for units 18 and 20, however, suggests the feature may actually be about 30 $\mathrm{cm}$ in diameter; thus, it may be from a larger post, perhaps the stain from an interior support post. It contains a very dark gray to black sandy loam fill. Contents: $1.73 \mathrm{~g}$ of charred plant remains, including wood charcoal, thick hickory nutshell, and acorn shell; 2 lithic debris; and 3 plain body sherds and 1 horizontal engraved sherd.

\section{Feature 17}

This feature, probably a pit, was exposed in the southeastern corner of Unit 23 between $33-46 \mathrm{~cm}$ bs. It has a dark brown sandy loam fill, and covers a $24 \mathrm{x} 12 \mathrm{~cm}$ area within the unit; the total size of the feature is unknown. A radiocarbon sample of $2.9 \mathrm{~g}$ of charred maize $(\mathrm{C} 13 / \mathrm{C} 12$ value of $-8.7 \mathrm{o} / \mathrm{oo})$ was submitted for dating purposes, and a calibrated radiocarbon date range of AD 1445-1660 (1 sigma) and AD 1410-1950 (2 sigma) was obtained from Beta Analytic, Inc. (Beta-129982). The intercepts of the radiocarbon age with the calibration curve are $\mathrm{AD} 1520,1575$, and 1625. The calibrated age ranges for the charred maize in Feature 17 seem unlikely given the context of the feature in the Southwest Village archeological deposits, the age of other radiocarbon dates from the Hudnall-Pirtle site, and the kinds of artifacts found in this habitation area; it appears, unfortunately, to have been contaminated by more modern charred plant materials. Contents: $3.28 \mathrm{~g}$ of charred plant remains, including the aforementioned maize cupules and glumes, and wood charcoal.

\section{Mound F}

Two features were excavated in the Mound F house mound. Small flotation samples (0.76-2.6 liters) were collected from both of the features in the mound.

\section{Feature 10}

This is a post hole that originates about $92 \mathrm{~cm}$ bs in the mound fill. It is about $20 \mathrm{~cm}$ in diameter, extends to $110 \mathrm{~cm}$ bs, has rounded sides and a flat bottom, with a dark brown charcoal-flecked fill. Based on profiles of the mound deposits (see Figure 19), and plan maps at various levels, this post appears to be possibly associated with part of an upper structure in the mound. At this depth, three other possible post holes (about $20-24 \mathrm{~cm}$ in diameter, but not formally recorded as features while the field work was underway) were noted to the west of 
Feature 10, along with a dark gray charcoal-flecked area covering all of Unit 3 and 25\% of adjoining Unit 11. This dark gray fill in profile is about $20-30 \mathrm{~cm}$ in thickness. Contents: $0.27 \mathrm{~g}$ of wood charcoal, thick hickory nut shell, and acorn shells; 2 plain body sherds.

\section{Feature 12}

Feature 12 refers to the burned house floor exposed near the bottom of the Mound F trench. Depending upon unit location in the mound trench, this feature originates between 112-126 cm bs (sloping to the west), and averages about $9 \mathrm{~cm}$ in thickness (bottom elevations between 129-136 cm bs); in some areas, however, it is as much as $16 \mathrm{~cm}$ in thickness. The house floor is characterized by a dark stain with considerable charcoal and ash, as well as charred cane. Calibrated radiocarbon age ranges of A.D. 1045-1223 (Beta-43539) and A.D. 10481250 (Beta-43540) were obtained from charcoal associated with the house floor (see Perttula 1998: Table 1). Contents: $0.44 \mathrm{~g}$ of charred cane stem, $1.40 \mathrm{~g}$ of wood charcoal, and two charred seeds.

\section{THE CERAMIC ASSEMBLAGE}

The ceramic assemblage from the 1989 and 1990 excavations at the Hudnall-Pirtle site includes vessel sherds, clay pipe sherds, ceramic ear-spool fragments, and clay daub (including amorphous burned clay pieces). The vast majority of the ceramics are vessel sherds, numbering 7,013 (see Appendix 2).

\section{Vessel Sherds}

Sherds from ceramic vessels are the most common artifacts from the 1989-1990 excavations at the site. Despite their high relative frequency (especially in parts of the Southwest Village and Well Pad areas), the sherds provide only basic information about the site, due largely to two factors. First, most of the sherds are small, measuring less than $6 \mathrm{~cm}$ in greatest dimension, and this hampers efforts to identify vessel shapes and to make typological assignments. The second factor limiting interpretation of the ceramic assemblage is the very small sample the sherds represent relative to the entire site. While $651 \times 1 \mathrm{~m}$ units and 70 shovel tests were excavated (see Figure 2), these represent but a tiny fraction of $1 \%$ of the site's archeological deposits. These limitations notwithstanding, the sherd assemblage - together with the other artifacts from Hudnall-Pirtle - provides at present the only insight into the use of the mound complex by Caddo people.

To provide basic descriptive information about the sherds, this section is broken into three basic groupings: wet-paste decorations on sherds; engraving (or "leather" hard-paste decorations) on sherds; and no decoration on plain sherds. Within the decorated groups, sherds are further sorted by basic design elements and, in some instances, motif. More detailed descriptions are provided for the decorated sherds than for the plain sherds. The reason for this, obviously, is that decorated sherds provide more temporal information about the site than do the plain body sherds. In reality, many of the plain body sherds are likely from the undecorated portions of the same vessels represented by the decorated sherds.

An additional basic grouping was used for analysis: very small sherds (or sherdlets) that measure less than 1 $\mathrm{cm}$ in diameter. These number 3,597 and represent about half of the total sherd count. Because of their small size and limited utility for understanding the ceramics found on the site, no observations are made other than to note them in this paragraph. The plain/decorated sherd ratio at the Hudnall-Pirtle site is 4.02 (2735/681). 


\section{Wet-Paste Decorations}

The sherds in this basic group, accounting for $78 \%$ of all sherds larger than $1 \mathrm{~cm}$ in diameter, are those decorated during the formation of the vessel when the clay body was wet. Simple decorations tend to occur, with incised lines and punctations common. Wall thickness in these sherds ranges from $3.5-12.75 \mathrm{~cm}$, and wall thickness is relatively uniform among the categories. The wet-paste decoration sherds are almost all utilitarian wares and are here classed as coarse wares.

We have subdivided the group into categories based on design elements and, in some instances, motifs. While ideally our division of these sherds would correspond to existing Caddo ceramic types (e.g., Suhm and Jelks 1962), the small size of the vast majority of the ceramics precludes this from being done reliably. However, once the sherds are sorted into basic design categories, comparisons with formal types can be made. The specific proveniences of these sherds are presented in Appendix 2.

\section{Incised Lines (Figure 23)}

A total of 213 sherds make up this category and represent $31 \%$ of all decorated sherds. On all but nine, the incised lines are parallel to each other. The width between the lines varies from about $4 \mathrm{~mm}$ to slightly more than $1 \mathrm{~cm}$ (Figure 23a-e). Both point-end and flat-end tools were used to make the incisions. On four sherds, the incisions were made by holding the cutting tool at a downward angle, creating overhanging lines. On the majority of the sherds (63\%), the orientation of the lines relative to the rim cannot be determined. But when the rim is present, the incisions are parallel to the rim $8 \%$ of the time, and I assume that most of the incised sherds with no observable orientation are also from vessels with lines oriented parallel to the rim. Of the nine sherds with lines that are clearly not parallel to the rim, seven have cross-hatched incised lines (Figure 23g), one has diagonal incised lines (Figure 23f), and one has perpendicular incised lines that do not overlap.

The majority (68\%) are tempered with grog, with lesser frequencies of bone (24\%) and a unidentified carbonized organic material (5\%). Observations about temper were made by visual inspection, occasionally aided by a magnifying glass. Three percent of the sherds have no observable temper. Paste textures range from coarse (largest grog particle size between 0.5 and $1 \mathrm{~mm}$ ) to fine (particle size between 0.15 and $0.25 \mathrm{~mm}$ ), with medium texture (particle size between 0.25 and $0.5 \mathrm{~mm}$ ) occurring $80 \%$ of the time.

All the vessels represented by these sherds are utility coarse wares and show little evidence of surface smoothing. Colors are most often very dark gray to dark brown and occasionally reddish-brown, with core colors usually darker than the exterior vessel surface (suggesting most of the vessels were fired in a reducing or low oxygen environment). Forms are most commonly simple bowls, and less frequently carinated or compound bowls. However, the small size of the sherds severely limits the number of instances in which vessel form can be determined.

Thirty-six percent of these sherds are parts of vessel rims. The rims are split about evenly between direct (uniform thickness to the lip) and thinned (tapering to the lip). Many of the rim sherds are from everted-wall vessels, while standing walls are less frequent. Lips are mostly flattened or rounded.

Many of the incised decorated sherds from Hudnall-Pirtle represent vessels similar to the type Davis Incised (Newell and Krieger 1949:116-118; Suhm and Jelks 1962:35-36; Brown 1996:356-357), although some may 


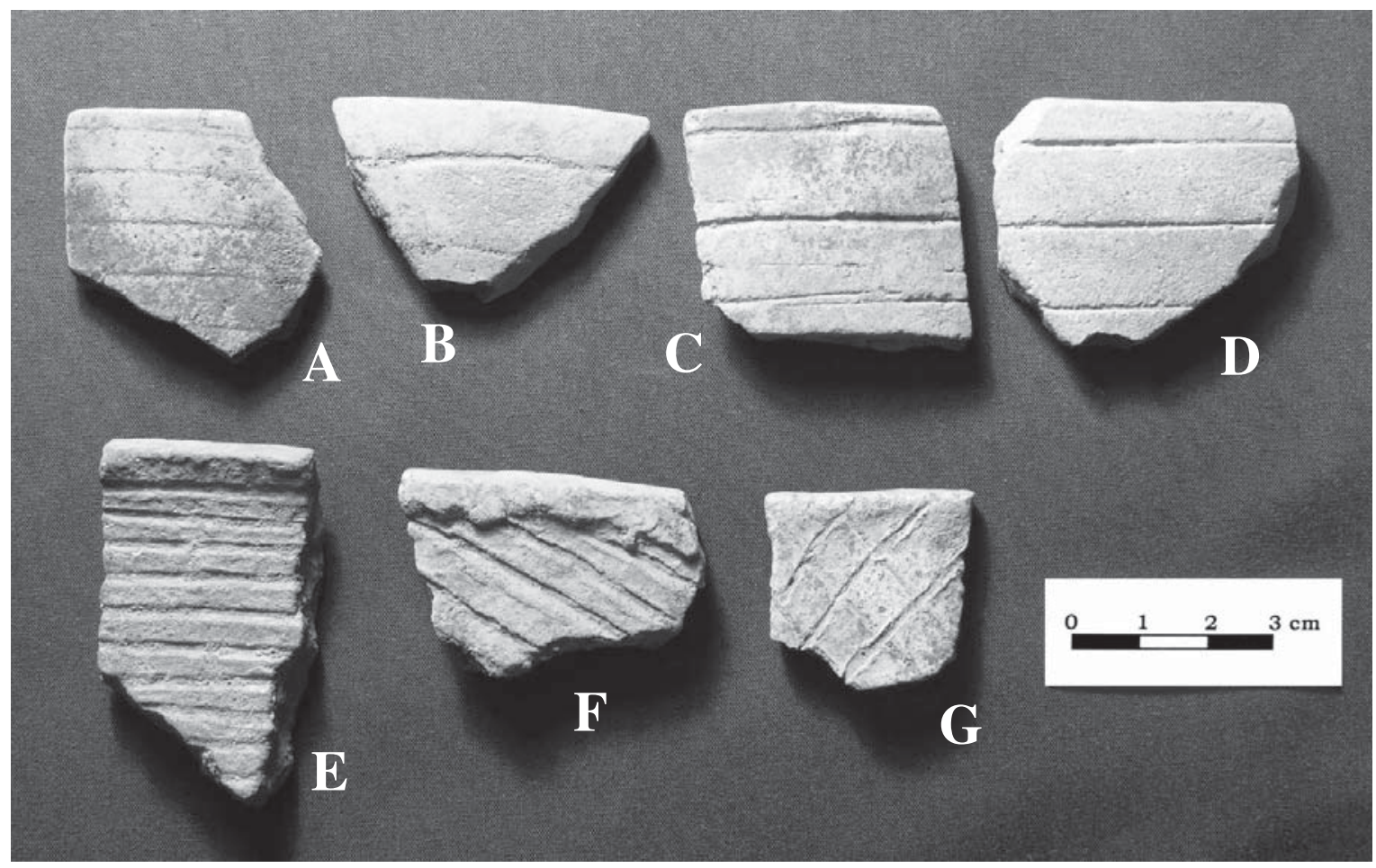

Figure 23. Incised rim sherds: (a-e) horizontal incised; (f) diagonal incised; (g) cross-hatched incised.

represent East Incised (Brown 1996:357-358; Suhm and Jelks 1962:41-42). The principal difference between the two is that the type East Incised does not include carinated bowls and bottles, has thinner walls and finer paste, and sometimes possesses rims with peaks and effigies. The Hudnall-Pirtle sample did include some carinated bowls and sherds with thinner walls and finer paste, but no peaked rims or effigy rims were observed.

Some of the sherds also quite possibly represent the rim portions of Kiam Incised vessels (Suhm and Jelks 1962:89-90). This type is defined as having horizontal incising surrounding the rim, often with vertically incised lines or punctations on the body. Since we have only the rim portions, this type cannot be conclusively identified among the incised sherds. Some sherds, especially those with parallel incised lines but without rims, may be portions of Dunkin Incised vessels (Newell and Krieger 1949:116-118; Suhm and Jelks 1962:35-36; Brown 1996:356-357). This type consists of parallel lines in a wide variety of patterns along the rim and body. Again, the small size of the sherds makes identification of this type difficult, although two small sherds - one with cross-hatched lines and another with perpendicular lines that do not overlap - are quite possibly of this type.

\section{Free Punctated Sherds (Figure 24)}

Free Punctated sherds are those sherds with punctations but without bordering incised lines, There is a total of 249 free punctated sherds in the Hudnall-Pirtle ceramic assemblage and they account for $47 \%$ of the decorated 
ceramics. They have been divided into six sub-categories based on type of punctation (Table 2). The most frequent type, accounting for about half the sherds, is termed "dragged fingernail punctation," and was made by inserting the end of a fingernail into the vessel body while the clay was wet and slightly dragging the fingernail downward (Figure 24a-d). The next most common type is termed "simple punctation" and is made the same as above, except that the fingernail is not pushed downward in the wet clay (Figure 24e-h). This technique was used on $37 \%$ of the punctated sherds.

In some cases an arch-shaped tool end, such as a reed held at an oblique angle, may have been used to make the decoration instead of a fingernail (see Figure 24h). Other, infrequent, decorative techniques include the use of triangular-end (see Figure 24d-e, h) and pointed-end tools (Figure 24g); circular reeds (Figure 24f); and pinched rows (Figure 24a-c), made by pressing the thumb and index fingernails into the clay at the same time, with the fingernail impressions placed end-to-end to form spiral lines or ridges. The pinched row punctations also tend to be mostly dragged, as described above.

The majority of these sherds are tempered with grog (75\%), followed by bone (19\%), carbonized organic material $(3 \%)$, and hematite $(1 \%)$. Temper appeared to be absent in $2 \%$ of these sherds. Paste textures are most frequently medium $(87 \%)$, followed by coarse $(9 \%)$ and fine $(4 \%)$. As with the incised sherds, all the vessels

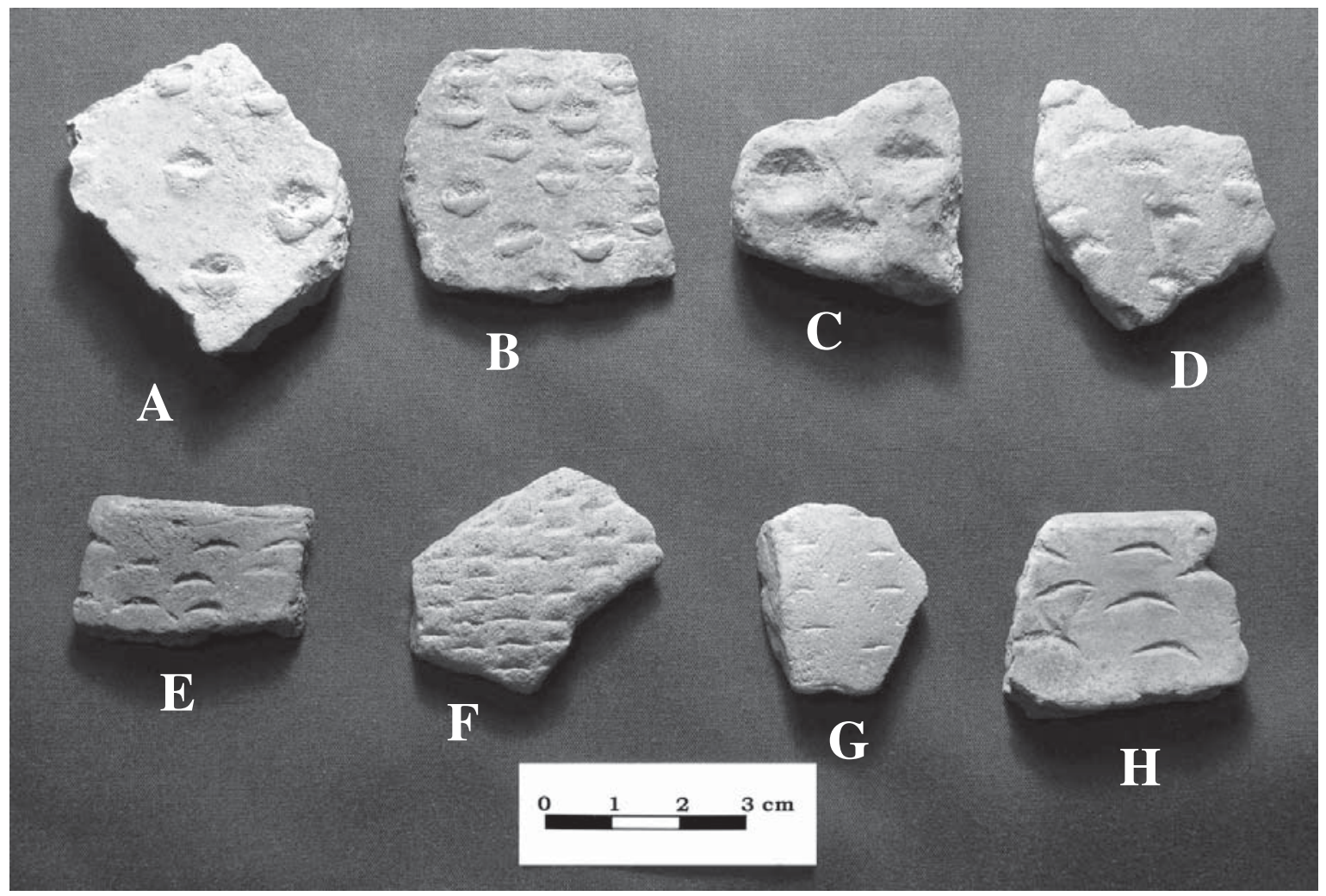

Figure 24. Punctated sherds: a-d, dragged fingernail punctation; e-h, simple fingernail punctation.

represent utility coarse wares, and are likely from similar, and in some instances the same, utility vessels as the incised sherds.

Sherds colors range from dark gray to dark brown to tan. A few reddish-brown sherd colors are also seen. Vessel forms, when identifiable, are simple bowls and, less commonly, carinated and compound bowls. Seven 
percent of the sherds are from vessel rims, and the rest are from bodies. Rims are evenly split between direct and thinned, and vessel wall orientation is mostly standing and less frequently everted or inverted. Lips are mostly flattened or rounded.

Many of the punctated sherds, especially those with fingernail or arched tool impressions (see Figure 24), undoubtedly represent vessels of Weches Fingernail Impressed (Newell and Krieger 1949:118-120; Suhm and Jelks 1962:153-154).

Table 2. Punctation design elements.

\begin{tabular}{lcc}
\multicolumn{1}{c}{ Technique } & Frequency & Percentage \\
\hline Dragged Fingernail & 117 & 73.6 \\
Simple Fingernail & 2 & 1.3 \\
Pinched Row & 16 & 10.1 \\
Triangular-end Tool & 11 & 6.9 \\
Pointed-end Tool & 7 & 4.4 \\
Spiral Punctated Lines & 4 & 2.5 \\
Circular Reed & 2 & 1.3 \\
\hline Total & 159 & 100.0
\end{tabular}

Others, such as those shown in Figure 25a-c, could be from the bodies of Kiam Incised or Dunkin Incised vessels. The triangular punctations could represent minor decorative variations of the punctated types mentioned above, or may be parts of other, untyped vessels. The circular reed punctations, such as shown in Figure 25f, likely represent small sherds from Crockett Curvilinear Incised vessels (Suhm and Jelks 1962:31-34).

The four sherds that have fingernail impressions placed end-to-end to form spiral lines or ridges are very similar to those observed on the body of a vessel of Weches Fingernail Impressed illustrated by Suhm and Jelks (1962:Plate 77i).

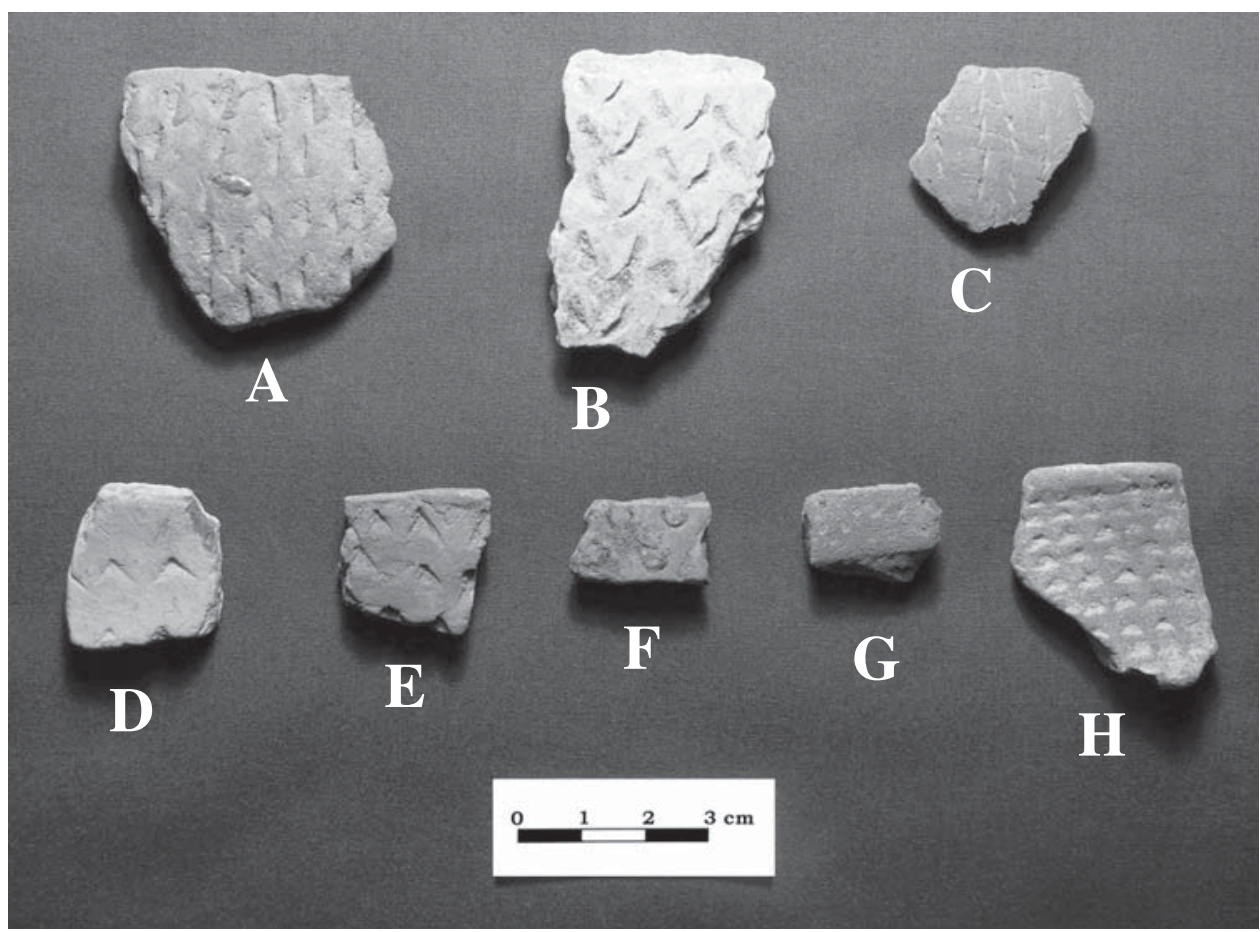

Figure 25. Punctated sherds: (a-c) pinched fingernail punctation; $(\mathrm{d}, \mathrm{e}, \mathrm{h})$ triangular-end tool punctation; (f) circular reed punctation; (g) pointed-end tool punctation. 


\section{Fingernail Punctations with Horizontal Incised Lines (Figure 26a-c)}

This design category consists of incised lines parallel to the rim, with semi-circular punctations in single rows between the lines. In most instances the punctations are made with fingernails, but in a few cases an arch-shaped tool end, such as the end of a large reed, may have been used (Figure 26a). All but one of the 29 sherds that make up this group have simple punctations, as defined above; the remaining sherd has dragged punctations. This design element is typically found on the rim, but on one sherd the body below is decorated with pinched punctations. Sherd colors vary from dark gray to reddish-brown to tan, with lighter colors more frequent. Sixty-eight percent are tempered with grog, and the remaining $32 \%$ are tempered with both grog and bone. Paste textures are mostly medium to coarse, and all of these sherds appear to have come from utility wares. The rim sherds are split between direct and thinned, and nearly all are from simple bowls with slightly everted rims. Lips are flat to round. All of these sherds fall into the type Weches Fingernail Impressed.

\section{Triangular-end Tool Punctations with Horizontal Incised lines (Figure 26d)}

The motif for these sherds is similar to Fingernail Punctations With Horizontal Incised Lines, with one major exception: the punctations are made by triangular-end tools. In some cases the punctations are made by solid tools and in others by hollow tools that represent an upside-down "V" when impressed into the clay. The 14 sherds that make up this sub-category range in color from dark gray to reddish-brown to tan. Half are tempered with grog, and half are tempered with both grog and bone. Among the four rim sherds, both thinned and direct rims are observed. Although the rim sherds are quite small (less than $4 \mathrm{~cm}$ in greatest dimension), they appear to be from simple bowls. Lips are rounded and pointed.

\section{Circular Punctations Within Linear Incised Lines (Figure 26f, h)}

This motif consists of flanked incised lines containing punctations. In the case of the three rim sherds in the sample, the incised flanked lines are diagonal to the rim. Thirteen sherds fall into this category, and the punctations on eight are made with a pointed-end tool, and three sherds have punctations made with hollow reeds. Colors range from dark gray to tan, with lighter colors most common. One sherd has no observable temper, six have grog, and four have a combination of grog and bone. The three rim sherds are too small to provide much reliable information about vessel shape. Both thinned and direct rims are present, and lips are both rounded and flattened. All these sherds fall within the type Pennington Punctated-Incised.

\section{Circular Punctations Within Curvilinear Incised Lines (Figure 26e, g)}

Three sherds have a design motif similar to Circular Punctations Within Linear Flanked Incised Lines described above, except that the incised lines are curvilinear instead of linear. The division of these two motifs based on the linearity of the incised lines follows the division made by Suhm and Jelks (1962:121) for sorting vessels between Pennington Punctated-Incised and Crockett Curvilinear Incised. All three sherds from Hudnall-Pirtle clearly fall within the type Crockett Curvilinear Incised (Suhm and Jelks 1962:31-32).

The single rim sherd in the sample shows an incised line about $2 \mathrm{~cm}$ below and parallel to the lip; triangularend tool punctations occur between the line and the lip. Another sherd appears to be part of a scroll motif of 


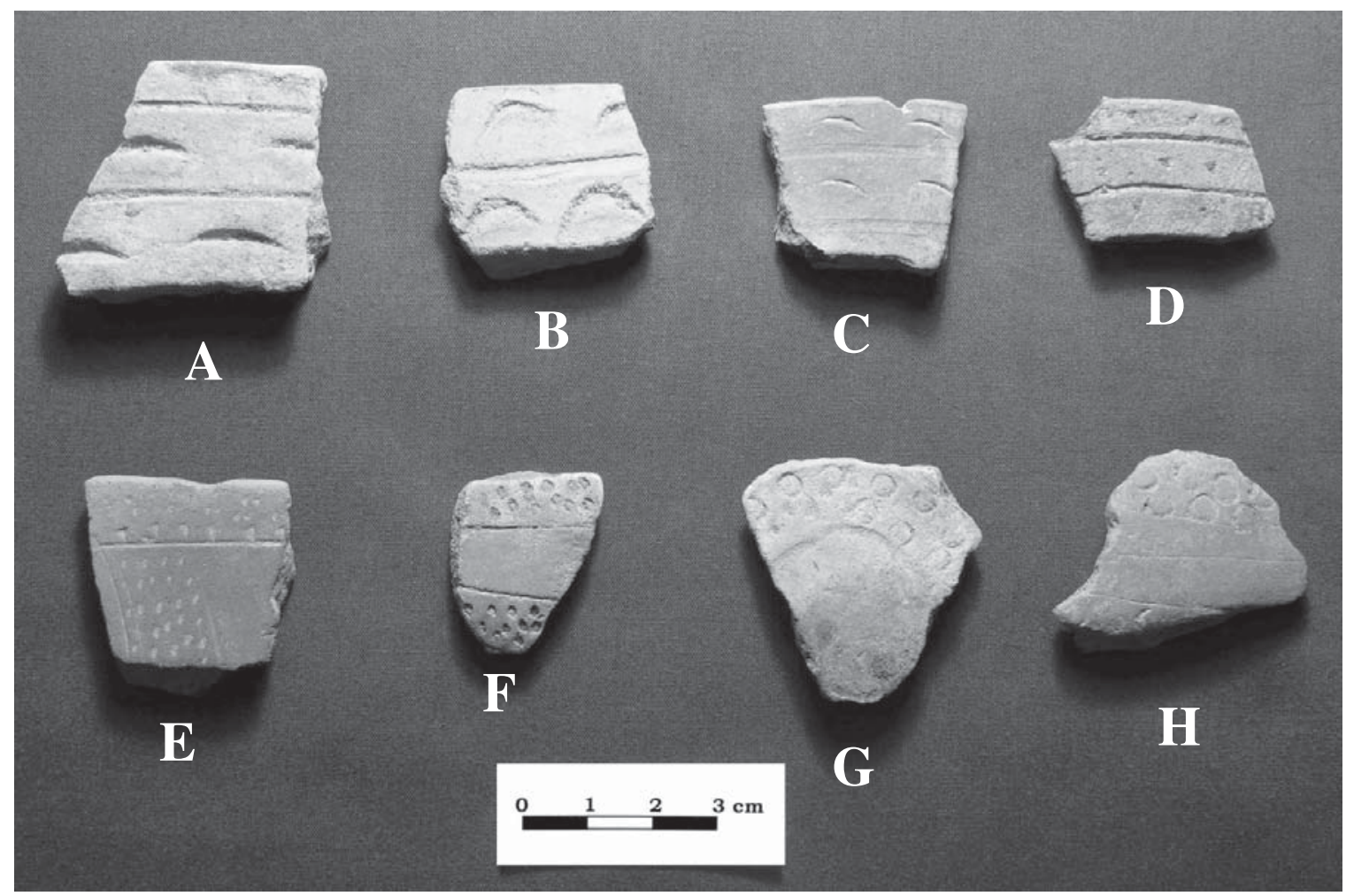

Figure 26. Incised/punctated sherds: $(\mathrm{a}-\mathrm{c})$ fingernail punctations with horizontal incised lines; (d) triangular-end tool punctations with horizontal incised lines; (e, f) circular punctations with linear incised lines; (g, h); circular punctations with curvilinear incised lines.

flanked curvilinear lines enclosing circular reed punctations, and the design on the last sherd is basically the same, but it forms a circle.

The sherds are dark brown to tan in color. Two are tempered with bone and grog and the other with hematite. The rim is thinned and slightly everted, and is probably from a simple bowl.

\section{Horizontal Incised Rim Lines with Body Punctations}

Two sherds make up this decorative category. The incised lines are identical to those on the other linear incisedline sherds from the site. However, these sherds are large enough to also contain portions of the vessel body, which are decorated with punctations. The body of one is decorated with free simple punctations and the other with pinching, forming rows running down the vessel. Colors are dark brown and gray. Both are tempered with grog and bone, and both have medium texture paste. These sherds are probably from vessels of Kiam Incised.

\section{Horizontal Incised Rim Lines with Single-Row Triangular-end Tool Punctations (Figure 27)}

Nine sherds exhibit the typical horizontal incised lines on the rim, but have enough of the body present to show that a single row of triangular-end tool punctations occurs below the last incised line. The incised triangles on all but two of the sherds were made with the right-angle corner of a hollow tool (Figure 27a, c). The other two sherds' triangular punctations were made with a solid tool with a triangular-shaped end (Figure 27b). Other 
than the decorations, these sherds are similar to the others from the incised/punctated category, with colors ranging from dark gray to dark brown to tan, and are mostly tempered with grog or both grog and bone. The tempers are grog $(n=5)$, bone and grog $(n=2)$, and lignite or carbonized organic material $(n=1)$. None of the sherds include the lip, so it is difficult to determine vessel shape, although simple bowls or jars seem most likely from the limited sherd sample. The sherds all represent examples of Coles Creek Incised (Phillips 1970:70-76); eight appear to be examples of Coles Creek Incised, var. Coles Creek, and one looks similar to Coles Creek Incised, var. Hardy.

\section{Engraved Decorations}

This major sherd category, with 149 examples representing $22 \%$ of all decorated sherds, consists of the engraved sherds from the Hudnall-Pirtle site. The distinction between these sherds and those in the wet-paste category is that the decorations on the engraved group were made after the clay body had dried and was in a "leather"hard stage. On the vessels decorated in this manner, lines are finer in width and not cut as deeply into the vessel body. This method of decoration requires an additional step in the overall process of making ceramic vessels, namely having to wait for the clay to dry before decorating the pot. Consequently, engraved vessels often represent finer wares, with better executed and more elaborate decorations. Specific proveniences of these sherds are presented in Appendix 2.

The engraved vessels are divided into four categories based on the orientation of the engraved lines. We have chosen this method of division because the categories best facilitate comparison with established Caddo ceramic types from Texas.

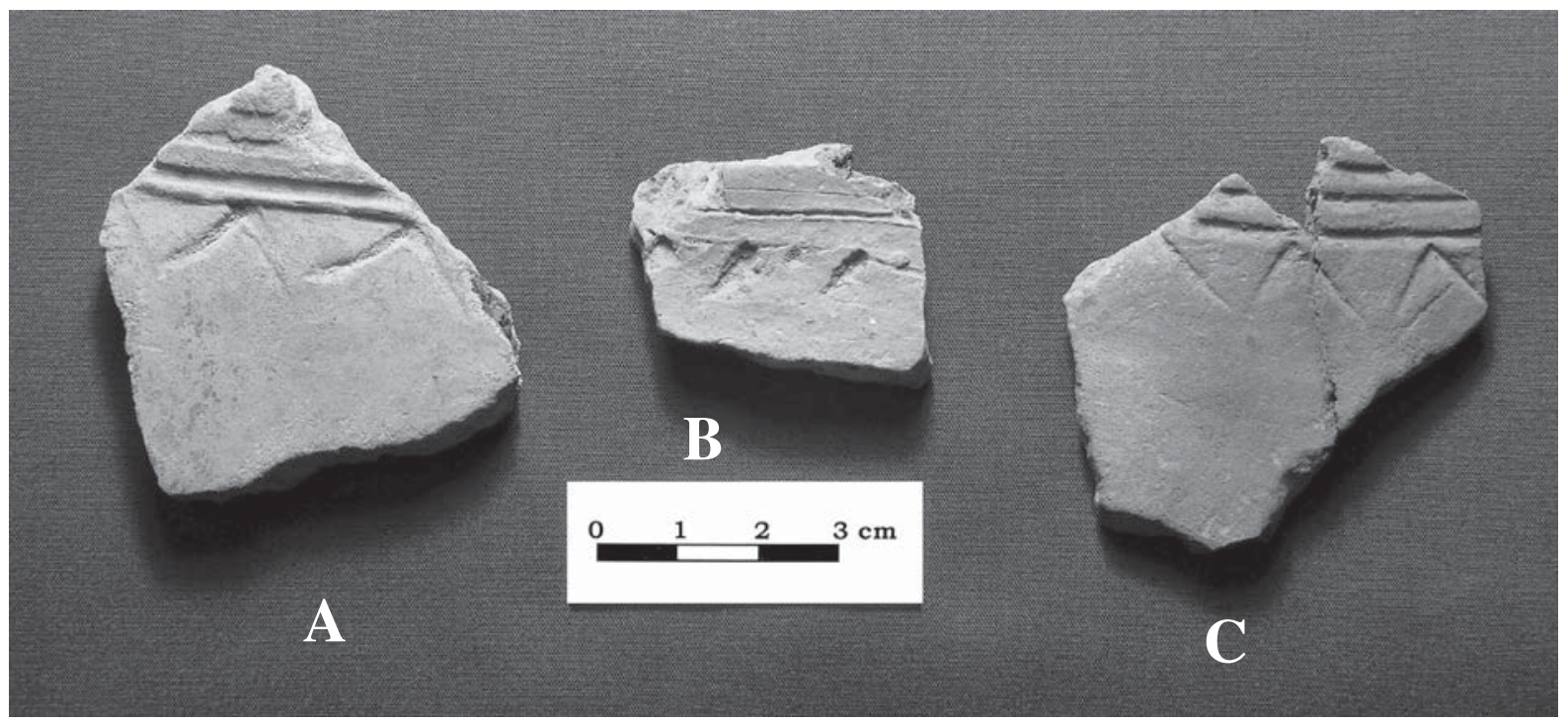

Figure 27. Horizontal incised rim lines with single-row triangular-end tool punctations (Coles Creek Incised). 


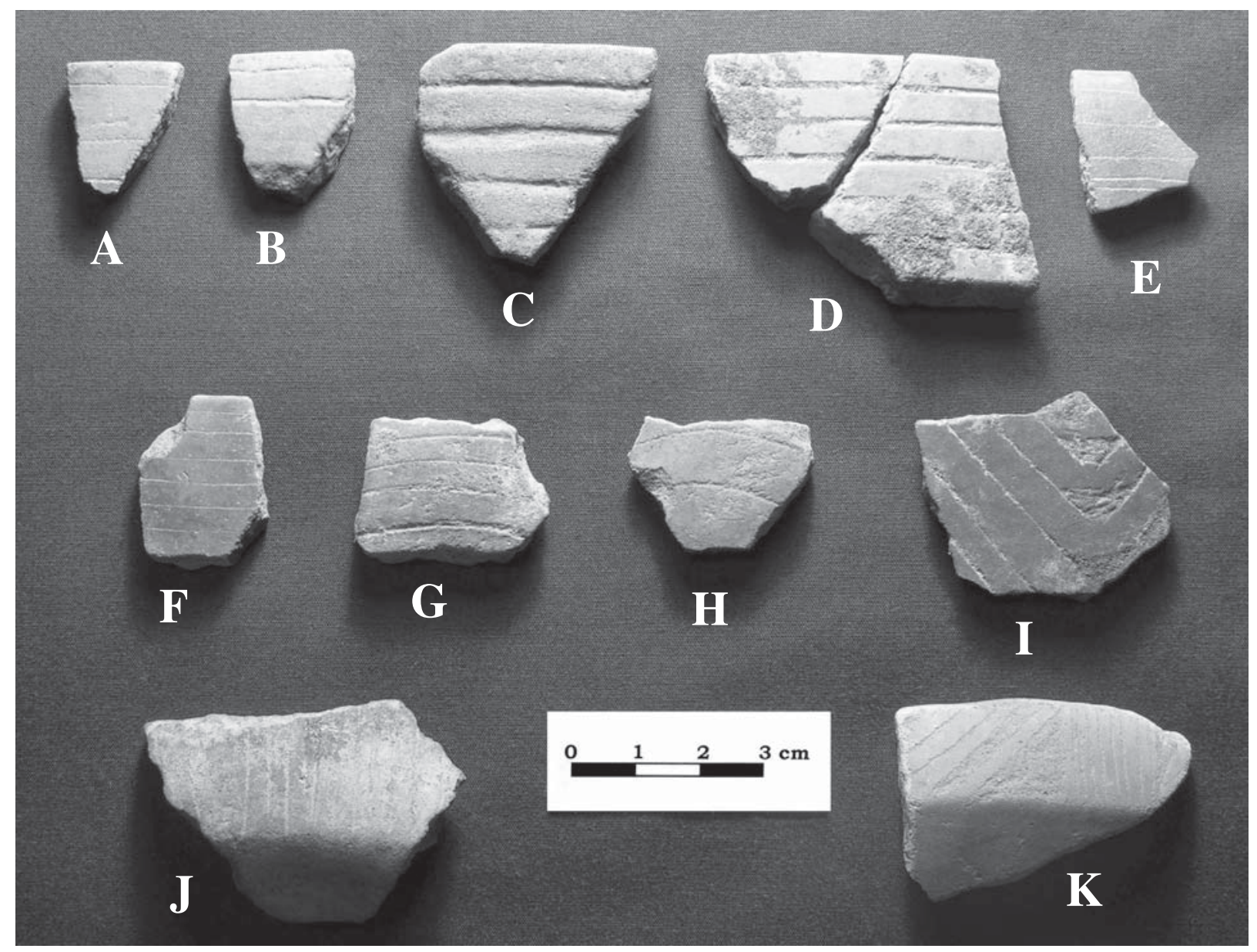

Figure 28. Engraved sherds: (a-f) horizontal lines; (g, h) concentric lines; (i) V-shaped lines with excised triangles; (j, k) vertical and diagonal lines.

\section{Horizontal Engraved Lines (Figure 28a-f)}

Thirty-one sherds make up this category and they are rims with one or more horizontal engraved lines parallel to the rim. On 28 specimens the lines are very finely made, less than $0.5 \mathrm{~mm}$ or less in width and depth. The remainder have slightly wider and deeper lines. The sherds are small and therefore the number of lines per vessel cannot be consistently determined, but up to seven are noted. Colors range from dark gray to brown to tan, and interior colors are usually darker than the exteriors.

The most common temper is bone and grog (45\%), followed by grog (40\%), and lignite or some other organic material (11\%). Two sherds had no observable temper. Pastes tend to be fine to medium, and wall thickness ranges from 4.0 to $7.6 \mathrm{~mm}$. Rims are usually thinned, and lips are pointed, rounded, and less commonly, flat. The sherds are all quite small, and thus vessel forms are difficult to determine accurately, but simple bowls are likely, and at least three bottles are present. Many of the sherds are likely from Hickory Fine Engraved vessels (Newell and Krieger 1949:90-91; Suhm and Jelks 1962:71-77; Brown 1996:373-374). It should be noted that although the ceramics are attributed to vessels of Hickory Fine Engraved, not all of the engraved decorations represent "fine engraved" lines. Rather, the Hudnall-Pirtle sherd sample contains many examples of design elements/motifs that are very similar, if not the same, as the fine engraved types, but the lines are thicker and generally coarser. 


\section{Concentric Engraved Lines (Figure 28g- h)}

Seventeen sherds comprise this category of engraved ceramics. All have one or more curving lines on the vessel body. In cases in which there is more than one line, the lines are parallel. In sherds with only one line, other parallel lines might have been present, but the sherds are too small to make this determination. The engraved lines on 13 specimens are finely made, while the others are wider and generally coarser. Colors range from dark gray to brown to tan, and interior colors are often darker than the exteriors. Temper is most commonly grog $(54 \%)$, followed by grog and bone (27\%) and carbonized material (13\%). No temper was observed in $7 \%$ of the sherds. Paste texture is fine to medium, and thicknesses range from a remarkably thin 2.5 to $5.2 \mathrm{~mm}$. Six sherds are polished on the exterior.

Only two rims are represented, and both are thinned with rounded lips. Vessel shapes are difficult to discern, but bowls, either simple or carinated, can be said to be a major part of the assemblage. These sherds are likely parts of Spiro Engraved and Holly Fine Engraved vessels (Newell and Krieger 1949:81-90; Suhm and Jelks 1962:77-7, 147-148; Brown 1996:374-376).

\section{Vertical Engraved Lines (Figure 28j, k)}

Fourteen sherds have vertical engraved fine lines. In one case the lines are separated by an excised triangle and then diagonal lines (see Figure 28k). In two other cases the rows of vertical lines are flanked by excised triangles. Colors range from dark gray to brown to tan, with interior color usually being darker. The temper is grog in all cases. Pastes are fine to medium, and one sherd has exterior polishing. Sherd thickness ranges from 4.5 to $9.9 \mathrm{~mm}$. Three of the sherds are rims: one is direct with a flat lip, and two are thinned rims with rounded lips. Four of the five sherds are from carinated bowls. The sherds are undoubtedly part of Holly Fine Engraved vessels (Suhm and Jelks 1962:77-79).

\section{Miscellaneous Engraved}

A total of 80 sherds fall into this sub-category, which is essentially a catchall for engraved sherds that lack rims or other diagnostic features such as rim carinations, to orient the decorations. Fifty sherds have two or more parallel lines, and of this number six are fine engraved. Fifteen sherds have a single engraved line, although the sherds are small enough that they may be parts of vessel decorations with multiple parallel lines. Eight sherds have engraved lines in a combination of orientations. Five of these have fine lines. Colors are the typical dark gray, brown, and tan. Sherd tempers include grog (48\%), bone and grog (35\%), and carbonized material (12\%). No temper was visible in $5 \%$ of the sherds.

One unique sherd has a series of V-shaped lines, some with excised triangles as part of the V-shaped lines (see Figure 28i). There is evidence that white pigment was rubbed into the lines. This vessel is likely a variation of Spiro Engraved. No vessel shapes could definitively be identified in the sample, and the decorations - other than the Spiro Engraved sherd - are most likely from Holly Fine Engraved and less likely from Hickory Fine Engraved vessels. 


\section{Undecorated Sherds}

Included in this category are plain body and rim sherds. As noted above, many of the plain body sherds are quite likely from the undecorated portions of vessels with rim decorations. The plain rims represent vessels that were undecorated.

\section{Undecorated Body Sherds}

A total of 2,636 plain body sherds were recovered; seven of these represent vessel bases. Colors span the range of dark gray, brown, and tan that is typical for ceramics from the site. Temper is predominantly grog (71\%), with less commonly bone and grog (12\%), grog and grit (5\%), grit or sandy paste (3\%), and carbonized organics $(1 \%)$. Thirty-six $(1 \%)$ of the undecorated sherds had no observable temper. Paste textures are mostly medium (73\%), coarse (19\%), and fine (8\%). Sherd thickness ranges from 3 to $12 \mathrm{~mm}$. Twenty-two of the sherds had polished surfaces, and five had red slipping on the exterior.

Sixty-seven sherds were large enough to allow identification of the vessel forms they represented, as follows: carinated bowls (48\%), bottles (21\%), simple bowls (16\%), compound vessels (10\%), and jars (5\%). However, as carinated bowls and jars tend to be easier to identify in small sherds, these figures represent only approximate percentages of the relative frequency of vessel forms.

\section{Undecorated Rim Sherds}

Among the undecorated vessel ceramics are 117 plain rim sherds. Their colors are in the same range as described above for the undecorated body sherds. Seventy-one percent of the rim sherds are tempered with grog, followed by $25 \%$ with grog and bone, and $1 \%$ with carbonized organic material. Temper was not observed in $3.2 \%$ of these sherds. Paste textures are mostly medium (90\%), followed by fine (7\%) and coarse (2\%). One rim sherd had a red slip on the exterior surface. Twenty-one sherds provide information about vessel form: $76 \%$ were simple bowls, $14 \%$ bottles, $4 \%$ carinated bowls, and $4 \%$ jars.

Rims are mostly thinned (58\%), with 33\% direct and 3\% rolled outward at the lip. Rim orientations were 37\% inverted, $27 \%$ standing, and $4 \%$ everted. Lips were most often flat or rounded.

\section{Summary of Vessel Sherds}

The distribution of basic decoration techniques among the areas of the Hudnall-Pirtle site that were investigated is shown in Table 3. Many areas of the site yielded too few sherds for statistically valid comparisons. But taking the two areas with the largest samples - Southwest and Well Pad - some differences can be observed that may indicate temporal trends in the vessel ceramics. The Southwest area has relatively more sherds with engraving and fewer with incisions. Both areas have similar frequencies of punctations and combined incised/ punctated sherds.

To better understand what this might indicate, Table 4 displays the basic decoration techniques broken down into element/motif categories and their distributions across the site areas. The correspondence between ele- 
Table 3. Decoration Techniques

\begin{tabular}{ccccccc} 
Area & Incised & Punctation & $\begin{array}{c}\text { Incised/ } \\
\text { Punctated }\end{array}$ & Engraved & Total & Percent \\
\hline Mound A & 2 & 3 & 2 & 4 & 11 & 1.6 \\
Mound F & 2 & 1 & & 1 & 4 & .6 \\
Northwest & 3 & 6 & & 6 & 15 & 2.3 \\
Pipeline & & 1 & 2 & & 3 & .5 \\
Southwest & 136 & 163 & 46 & 88 & 433 & 65.3 \\
Shovel Tests & 4 & 7 & 2 & 8 & 21 & 3.2 \\
Well Pad & 58 & 54 & 15 & 25 & 152 & 22. \\
No Area & 8 & 14 & 3 & 1 & 26 & 3.8 \\
\hline Total & 213 & 249 & 70 & 131 & 663 & 100.0 \\
Percent & 32.1 & 37.6 & 10.6 & 1.7 & 100.0 &
\end{tabular}

Table 4. Distribution of Vessel Ceramics by Site Area

\begin{tabular}{|c|c|c|c|c|c|c|c|c|c|c|}
\hline $\begin{array}{l}\text { Decoration } \\
\text { Method }\end{array}$ & Element/Motif Category & $\begin{array}{l}\text { Mound } \\
\mathrm{A}\end{array}$ & $\underset{F}{\text { Mound }}$ & Northwest & Pipeline & Southwest & $\begin{array}{l}\text { Shovel } \\
\text { Tests }\end{array}$ & $\begin{array}{l}\text { Well } \\
\text { Pad }\end{array}$ & $\begin{array}{l}\text { No } \\
\text { Area }\end{array}$ & Total \\
\hline \multicolumn{11}{|l|}{ Wet Paste } \\
\hline & Incised Lines & 2 & 2 & 3 & & 136 & 4 & 58 & 8 & 213 \\
\hline & Free Punctates & 3 & 1 & 6 & 1 & 163 & 7 & 54 & 14 & 24 \\
\hline & $\begin{array}{l}\text { Fingernail Punctations with Horizontal } \\
\text { Lines }\end{array}$ & 1 & & & 1 & 1 & 2 & 5 & 1 & 2 \\
\hline & $\begin{array}{l}\text { Triangular-end Tool Punctations with } \\
\text { Horizontal Incised lines }\end{array}$ & & & & & 10 & & 3 & 1 & 14 \\
\hline & $\begin{array}{l}\text { Circular Punctations with Linear Incised } \\
\text { lines }\end{array}$ & 1 & & & & 8 & & 3 & 1 & 13 \\
\hline & $\begin{array}{l}\text { Circular Punctations Within Curvilinear } \\
\text { Incised Lines }\end{array}$ & & & & & 2 & & 1 & & 3 \\
\hline & $\begin{array}{l}\text { Horizontal Incised lines with Body } \\
\text { Punctations }\end{array}$ & & & & & 2 & & & & 2 \\
\hline & $\begin{array}{l}\text { Horizontal Incised Rim Lines with Single- } \\
\text { Row Triangular-end Tool Punctations }\end{array}$ & & & & 1 & 5 & & 3 & & \\
\hline Total Wet & Decorated Sherds & 7 & 3 & & 3 & 345 & 13 & 127 & 25 & 532 \\
\hline \multicolumn{11}{|l|}{ Engraved } \\
\hline & Horizontal Engraved Lines & & & 2 & & 24 & 3 & & & 38 \\
\hline & Concentric Engraved Lines & 1 & & 1 & & 10 & & 5 & & 17 \\
\hline & Vertical Engraved Lines & 3 & & 1 & & 8 & 2 & & & 14 \\
\hline & Misc. Engraved & & 1 & 3 & & 56 & 4 & 14 & 2 & 80 \\
\hline \multicolumn{2}{|c|}{ Total Engraved Sherds } & 4 & 1 & 7 & 0 & 8 & & 28 & 2 & 14 \\
\hline Total Decora & herds & 11 & 4 & 16 & 3 & 443 & 22 & 155 & 27 & 681 \\
\hline \multicolumn{11}{|c|}{ Undecorated Sherds } \\
\hline & Undecorated Body Sherds & 41 & 20 & 3 & 4 & 1,650 & 4 & 818 & 15 & 2,636 \\
\hline & Undecorated Rim Sherds & & & 3 & & 87 & & 27 & & 117 \\
\hline \multicolumn{2}{|c|}{ Total Undecorated Sherds } & 41 & 20 & 42 & 4 & 1,737 & 4 & 845 & 15 & 2,753 \\
\hline \multicolumn{2}{|c|}{ Total Non-Small Sherds (greater than $1 \mathrm{~cm}$ ) } & 52 & 24 & 58 & 7 & 2,180 & 71 & 1,000 & 42 & 3,434 \\
\hline \multicolumn{2}{|c|}{ Small Sherds (less than $1 \mathrm{~cm}$ ) } & 30 & 1 & 121 & 2 & 848 & 171 & 2,387 & 1 & 3,57 \\
\hline \multicolumn{2}{|c|}{ Total Vessel Sherds } & 82 & 43 & 17 & & 3,028 & 242 & 3,387 & 61 & 7,031 \\
\hline
\end{tabular}


Table 5. Comparison of Design Element/Motif Categories with Published Ceramic Types

\begin{tabular}{|c|c|c|c|c|}
\hline Decoration Method & Design Element/Motif Category & $\begin{array}{l}\text { Similar Published } \\
\text { Ceramic Types }\end{array}$ & Frequency & Percent \\
\hline \multicolumn{5}{|l|}{ Wet Paste (Coarsewares) } \\
\hline & Incised Lines & $\begin{array}{l}\text { Davis Incised and } \\
\text { less likely East } \\
\text { Incised, Kiam } \\
\text { Incised, and Dunkin In }\end{array}$ & 213 & 31.28 \\
\hline & Free Punctates & $\begin{array}{l}\text { Weches } \\
\text { Fingernail } \\
\text { Impressed, less } \\
\text { commonly Kiam } \\
\text { Incised, Dunkin } \\
\text { Incised, and } \\
\text { Crockett } \\
\text { Curvilinear Incised }\end{array}$ & 24 & 3.5 \\
\hline & Fingernail Punctations with Horizontal Lines & $\begin{array}{l}\text { Weches Fingernail } \\
\text { Impressed }\end{array}$ & 2 & 0.2 \\
\hline & $\begin{array}{l}\text { Triangular-end Tool Punctations with Horizontal } \\
\text { Incised lines }\end{array}$ & $\begin{array}{l}\text { Variant of Weches } \\
\text { Fingernail } \\
\text { Impressed? }\end{array}$ & 14 & 2.06 \\
\hline & Circular Punctations with Linear Incised lines & $\begin{array}{l}\text { Pennington } \\
\text { Punctated-Incised }\end{array}$ & 13 & 1.2 \\
\hline & $\begin{array}{l}\text { Circular Punctations Within Curvilinear Incised } \\
\text { Lines }\end{array}$ & $\begin{array}{l}\text { Crockett } \\
\text { Curvilinear Incised }\end{array}$ & 3 & .44 \\
\hline & & Kiam Incised & 2 & .2 \\
\hline & $\begin{array}{l}\text { Horizontal Incised lines with Body Punctations } \\
\text { Horizontal Incised Rim Lines with Single-Row } \\
\text { Triangular-end Tool Punctations }\end{array}$ & $\begin{array}{l}\text { Coles Creek } \\
\text { Incised, var. Coles } \\
\text { Creek and Hardy }\end{array}$ & 9 & 1.32 \\
\hline \multirow{6}{*}{$\begin{array}{l}\text { Total Wet-Paste Decor } \\
\text { Engraved (Fine wares) }\end{array}$} & Sherds & & 532 & 78.12 \\
\hline & & & & \\
\hline & Horizontal Engraved Lines & $\begin{array}{l}\text { Hickory Fine } \\
\text { Engraved }\end{array}$ & 38 & 5.58 \\
\hline & Concentric Engraved Lines & $\begin{array}{l}\text { Holey Fine } \\
\text { Engraved, Spiro } \\
\text { Engraved }\end{array}$ & 17 & 2.50 \\
\hline & Vertical Engraved Lines & $\begin{array}{l}\text { Holey Fine } \\
\text { Engraved }\end{array}$ & 14 & 2.06 \\
\hline & Misc. Engraved & $\begin{array}{l}\text { Holey Fine } \\
\text { Engraved and less } \\
\text { so Hickory Fine } \\
\text { Engraved }\end{array}$ & 80 & 11.75 \\
\hline Total Engraved Sherds & & & 149 & 21.8 \\
\hline Total Decorated Sherds & & & 681 & 100.0 \\
\hline
\end{tabular}

ments/motifs and published Texas Caddo types is presented in Table 5. The results show that many categories occur in most areas of the site, but some subtle differences are apparent in the distribution.

Again using the Southwest and Well Pad areas, where sample sizes are largest, the Southwest area can be seen to have more Free Punctation sherds, indicative of Weches Fingernail Impressed. Newell and Krieger (1949:119) have argued that there was a trend from zoned punctates to free punctates over time at George C. Davis. Although not everyone has agreed with this observation (Stokes and Woodring 1981:181), if we assume that there is validity to Newell and Krieger's observation, the Southwest area seems to have been occupied somewhat later than the Well Pad area. Adding additional support to this observation is the distribution of Horizontal Incised Rim Lines with Single-Row Triangular-end Tool Punctations, or Coles Creek Incised. This type occurs slightly more frequently in the Well Pad area. As Coles Creek Incised is believed to be very early occurrence in the Caddo ceramic sequence (ca. A.D. 950-1050), it too suggests that the Well Pad occupation is earlier than the Southwest village area.

Of likely statistical significance is the relative occurrence of the element/motif category Vertical Engraved Lines, present in seven sherds from the Southwest area and entirely missing from the Well Pad. If the proposal of temporal differences between the two areas is true, this suggests that this element/motif, part of the Holly Fine Engraved type, occurs slightly later in the overall Caddo sequence at the Hudnall-Pirtle site. 
A final observation from Table 4 is that engraving is overall slightly less frequent in the Well Pad area. At the Davis site, engraving is much more common than at Hudnall-Pirtle (Newell and Krieger 1949:Table 13; Stokes and Woodring 1981). The argument can be made that this again supports a somewhat earlier occupation at the Well Pad area, when engraving was less commonly used as a decorative technique. As time progressed, it increased in frequency of use and reached a zenith during the subsequent occupation of the Davis site.

In terms of a more general comparison, the Hudnall-Pirtle sample compares quite well to the ceramic from the George C. Davis site. While the relative frequencies of some types occur in different proportions, all the major ceramic types are found at both places, with the exception of Duran Neck Banding, which is lacking in the Hudnall-Pirtle ceramic assemblage.

\section{Burned Clay and Daub}

A total of $434.1 \mathrm{~g}$ of burned clay and daub was found during the excavations at the Hudnall-Pirtle site. The distinction between the two is that burned clay does not have surface stick or thatch impressions, while daub does. Burned clay can be from hearths, from the clay applied to the exterior of structures but without preserved stick or thatch impressions, and from other sources where clay came into contact with high heat. Daub, on the other hand, is almost exclusively from wattle and daub-covered structures, and the impressions on the exterior covering of the structures allow this identification. The vast majority (79\%) of the fired clay from the site is burned clay, mostly tan in color, with lesser amounts of dark brown, fired sandy clay. The specimens come mainly from the Southwest and Well Pad areas (Table 6). A small amount comes from Shovel Test 3, located $35 \mathrm{~m}$ east of the Southwest village units (Table 7; see Figure 2).

Table 6. Burned Clay and Daub by Area

\begin{tabular}{ccccc} 
& \multicolumn{2}{c}{ Burned Clay } & \multicolumn{2}{c}{ Daub } \\
Area & $\#(\mathbf{g})$ & $\mathbf{\%}$ & $\#(\mathbf{g})$ & $\mathbf{\%}$ \\
\hline Northwest & & & 1.2 & 25 \\
Southwest & 316.7 & 73.6 & 2.0 & 43 \\
Shovel Tests & 3.7 & 0.9 & 1.5 & 32 \\
Well Pad & 109 & 25.5 & & \\
\hline Total & 429.4 & 100.0 & 4.7 & 100.0
\end{tabular}

The small amount of daub, indicating structures, consists of small pieces with stick impressions of about 3-8 $\mathrm{mm}$ in diameter. The pieces are tan in color and made of fired sandy clay. They come from three locations: a unit in the Southwest, a unit in the natural mound of the Northwest, and Shovel Test 8, located $150 \mathrm{~m}$ to the east of the Southwest units (see Figure 2).

When the proportion of burned clay is compared with that of vessel ceramics, burned clay is more prevalent in the Southwest area than in the Well Pad area. As little daub was found in these two areas, it is not clear what the higher proportion of burned clay from the Southwest area represents. Perhaps the clay is from hearths, proportionally more of which were excavated during the 1989-1990 fieldwork. It should be noted that the site soils have been extensively bioturbated, making field identification of hearths difficult, so the true source of the burned clay will never be known. The low frequency or absence of daub from these two areas does strongly suggest that the structures built here were not daubed with clay. 
There is evidence from the distribution of daub that a daubed structure might have existed around Unit 6 in the Southwest area (see Figure 2), around Shovel Test 8 to the east of the Southwest units, and along the southern slope of the natural mound in the Northwest.

\section{Other Fired Clay Artifacts}

\section{Pipe Fragments (Figure 29a-c)}

One possible and six definite pipe fragments were recovered in the excavations. The definite pipe fragments are all from long-stemmed Red River variety pipes (Figure 29a-b; Hoffman 1967; Brown 1996:512). Three of them are from the pipe stem and three from the pipe bowl. The diameters of the stems are $2.6 \mathrm{~mm}, 2.9 \mathrm{~mm}$, and $1.6 \mathrm{~mm}$. Colors are tan and gray. The paste textures are fine to medium; bone was added to four of them, while two have no visible temper. Four of the Red River-style pipe fragments are from the Well Pad (Unit-Levels 103-7, 106-4, 106-7, and 116-1), and two from the Southwest (Unit-Levels 4-1 and 20/21-6).

One sherd, tentatively identified as part of a platform pipe, is illustrated in Figure 29c. It consists of a fragment of fired clay with three smooth faces and it has been broken along the other edge. The smooth faces suggest that the pipe platform had a flat base, an everted side, and a convex top, with a hole in the center that formed the pipe's bowl. The color of the sherd is tan with some areas of black smudging. The temper is bone and grit, and the texture is medium to coarse. The pipe fragment is from Unit-Level 21-3 in the Southwest area.

\section{Ear Spools (Figure 29d-f)}

Four ear-spool sherds were recovered from the site. Three are clay rings with pronounced flanges along both exterior edges. The other example is a ring with a concave exterior. The sherds range in color from tan to gray. The paste textures are fine, and there is no visible temper in the clay. The rings with flanged edges average $2 \mathrm{~mm}$ in wall thickness; the non-flanged specimen is $5.7 \mathrm{~mm}$ in wall thickness at the thinnest part. Two ear-spool fragments are from the Well Pad (Unit-Levels 112-2 and 123-2). One is from the Southwest (Unit-Level 20-3), and one is from Shovel Test 9 south of Mound B (see Figure 2).
Table 7. Burned Clay and Daub by Provenience.

\begin{tabular}{|c|c|c|}
\hline $\begin{array}{l}\text { Provenience } \\
\text { (Unit-Level) }\end{array}$ & $\begin{array}{l}\text { Burned } \\
\text { Clay (g) }\end{array}$ & $\begin{array}{c}\text { Daub } \\
(\mathrm{g})\end{array}$ \\
\hline $2-8$ & & 1.2 \\
\hline $4-4$ & 6.2 & \\
\hline $4-4$ & 2.7 & \\
\hline $4-5$ & 12.4 & \\
\hline $5-3$ & 1.6 & \\
\hline $6-3$ & 2. & \\
\hline $6-5$ & 1.6 & \\
\hline $8-1$ & 1.3 & \\
\hline $12-3$ & 18.5 & \\
\hline $12-5$ & 7.8 & \\
\hline $12-5$ & 1.8 & \\
\hline $13-5$ & 7.4 & \\
\hline $16-2$ & 3.1 & \\
\hline $16-4$ & .5 & \\
\hline $18-3$ & 2.6 & \\
\hline $18-6$ & 2.1 & \\
\hline $18-7$ & 3.5 & \\
\hline $18 / 20-5$ & 13.2 & \\
\hline $18 / 20-5$ & 11.6 & \\
\hline $20-3$ & 4.5 & \\
\hline $20-4$ & 1.0 & \\
\hline $20-6$ & 41.3 & \\
\hline $21-0$ & 7.3 & \\
\hline $21-3$ & 3.2 & \\
\hline $21-4$ & 3.1 & \\
\hline $21-5$ & 8.6 & \\
\hline $21-5$ & 18.1 & \\
\hline $22-2$ & & 2.0 \\
\hline $103-7$ & 5.5 & \\
\hline $112-2$ & 3.7 & \\
\hline $118-2$ & 3.1 & \\
\hline $11-2$ & 2.8 & \\
\hline $122-1$ & 7.3 & \\
\hline $125-4$ & . & \\
\hline $128-2$ & 6.0 & \\
\hline $138-2$ & 4.6 & \\
\hline $13-4$ & 87.0 & \\
\hline Feature 13 & 30.1 & \\
\hline Feature 14 & 5.7 & \\
\hline Feature 14 & 5.1 & \\
\hline Feature 104 & 17.0 & \\
\hline Feature 110 & 61.8 & \\
\hline Shovel Test 3 & 3.7 & \\
\hline Shovel Test 8 & & 1.5 \\
\hline Total & 429.4 & 4.7 \\
\hline
\end{tabular}




\section{Vessel Legs (Figure 29g, h)}

Two small conical legs from vessels are part of the ceramic assemblage. Both appear to have been made separately and then pressed onto the vessels. One is tempered with grog and bone; the other has no visible temper. Both legs show evidence of post-firing burning, apparently from the direct contact of utilitarian cooking vessels with a hearth fire. They are tan in color, except for dark brown to black burned areas, and are from the Southwest (Unit-Levels 4-5 and 21-2).

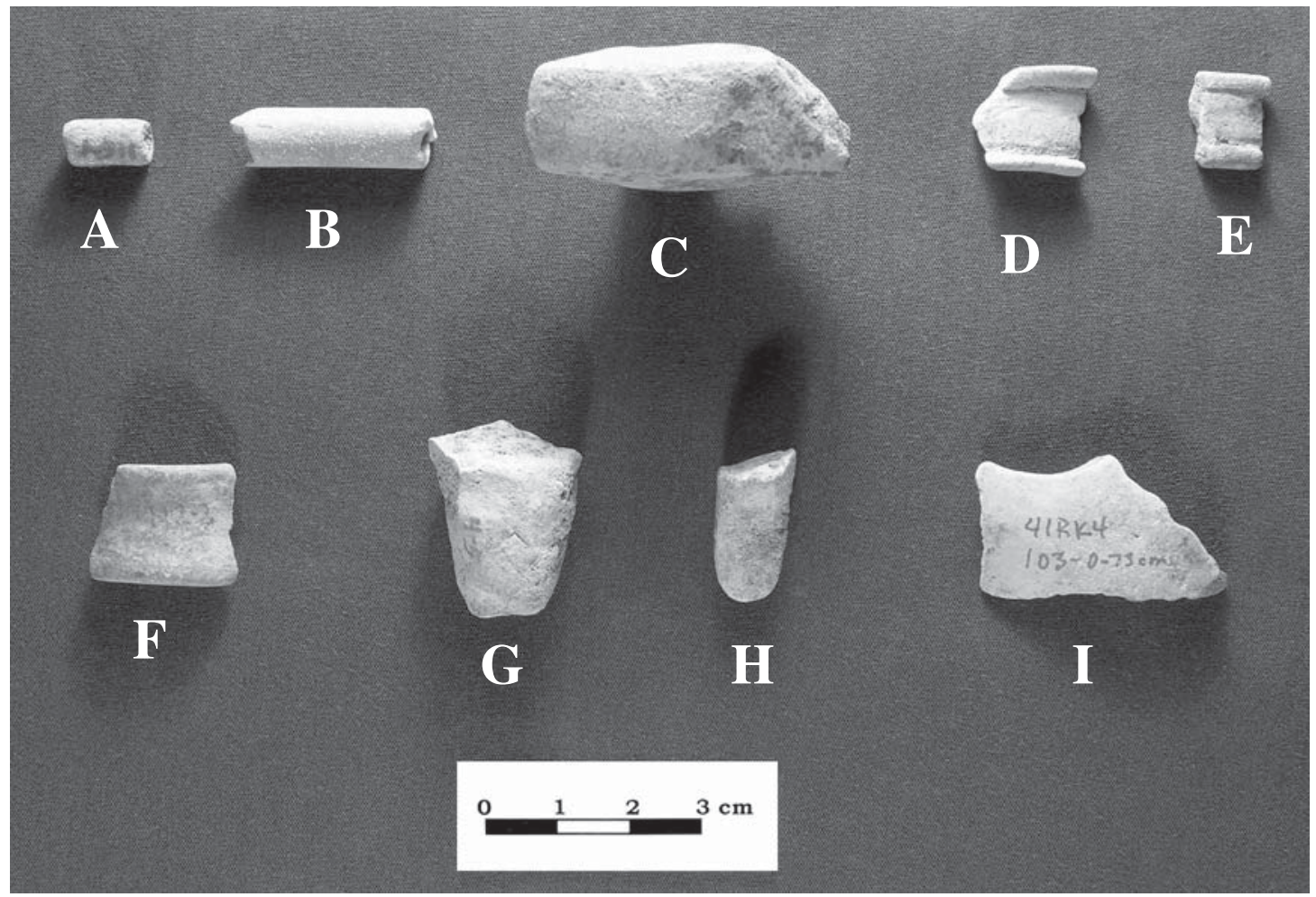

Figure 29. Other fired clay artifacts: (a-c) pipe fragments; (d-f) ear spools; (g, h) vessel legs; (i) unknown.

\section{Unknown Fired Clay Fragment (Figure 29i)}

One piece of fired clay has a flat convex and smoothed exterior surface and a broken underside. A smoothed, and presumably central, hole is present along one edge of the surface. The color is tan on the exterior with a dark gray core. The paste is medium, and no visible temper is present. The object is from the Well Pad (Unit-Level 103-7) and is remarkably similar to artifacts described as "fragments of clay disks cut from sherds, smoothed central hole; spindle whorls(?)" by Newell and Krieger (1949), who include an illustration of one in their Figure 53F. The purpose of the Hudnall-Pirtle example is unknown.

\section{THE LITHIC ARTIFACTS FROM THE HUDNALL-PIRTLE SITE (41RK4)}

It is rare in prehistoric Northeast Texas archeological investigations - given the cultural preference by aboriginal peoples over thousands of years to reoccupy and use the same favorable landforms and topographic settings - to 
retrieve large samples of material culture remains from clear single component contexts (see Story 1990; Collins and Bousman 1993). In most cases, the artifacts recovered from prehistoric archeological sites represent a palimpsest of multiple, recurrent, and overlapping occupations that had no cultural association in the past, and certainly possess little obvious cultural integrity in the present.

Consequently, analysis of the archeological remains from sites in these types of settings typically are extremely descriptive (usually in the absence of any stated and potentially testable research problems of more than passing interest). They focus on shared characteristics of the artifact groupings as a whole since more discrete groupings (either temporal or spatial in nature) are difficult to justify and even harder to isolate, and end up contributing little new information on the character of prehistoric material culture or the human behavior that produced it. The relatively large lithic artifact assemblage from the Hudnall-Pirtle site is thus of more than passing interest in the study of the Northeast Texas archeological record because it clearly seems to derive from a major prehistoric Caddo ceremonial center of discrete and well-preserved Early Caddoan period context (ca. A.D. 1000-1200).

The study of the lithic artifacts recovered in the 1989-1990 excavations at Hudnall-Pirtle foremost provide an excellent opportunity to characterize the nature of certain kinds of chipped and groundstone tools being manufactured and used at that time along the Sabine River by Caddo peoples. Assemblage-wide comparisons with other contemporaneous sites in the Sabine River drainage (such as James Pace; see Girard 1994) and Boxed Springs (see Perttula et al. 2000) in northwestern Louisiana and Northeast Texas, and in Northeast Texas generally, should also provide useful insights on tool diversity and the functional nature of the Hudnall-Pirtle tool assemblage, and whether there is any significant intra-site differences along these dimensions. Finally, examination of the lithic raw materials present in the collection will provide some measure of the acquisition and use of non-local raw materials by the Caddo peoples at Hudnall-Pirtle; archeological evidence from the Sabine River drainage suggests that the use of non-local lithic raw materials was extensive during Early Caddo times (cf. Bruseth and Perttula 1981; Perttula 1984), and it is expected that the use of non-local lithic raw materials would be relatively extensive in an important site used for civic and ceremonial activities.

\section{THE LITHIC ASSEMBLAGE}

The lithic artifact sample from the 1989-1990 excavations at the Hudnall-Pirtle site includes 309 chipped and ground stone tools, 91 cores, and 2770 pieces of lithic debris. The largest numbers of tools, cores, and debris are from, not too surprisingly, the areas of the site where excavations were most intensive: the Well Pad and the Southwest area (Figure 30), modified from the site base map in Bruseth [1991]). About 86\% of the site's tools and cores, and $84 \%$ of the lithic debris, were recovered in these two excavation areas. The Northwest area contributed about another $7 \%$ of the tools and cores and $8 \%$ of the lithic debris. The remainder of the lithic assemblage comes from general site shovel testing, limited investigations in Mounds A and F, the monitoring of the pipeline trench between the Well Pad and Mound C, and the Plaza. Plotting the distribution of shovel tests with lithic debris, tools, and cores (see Figure 30) from the site reveal a broad and large circular area with such remains, marking the general extent of the extensive habitation areas outside of the plaza and the ring of mounds. There are apparently more localized areas of habitation deposits amidst Mounds $\mathrm{F}$ and $\mathrm{H}$ in the southeastern part of the civic-ceremonial center; immediately north of Mound A; and southeast of Mound E. 


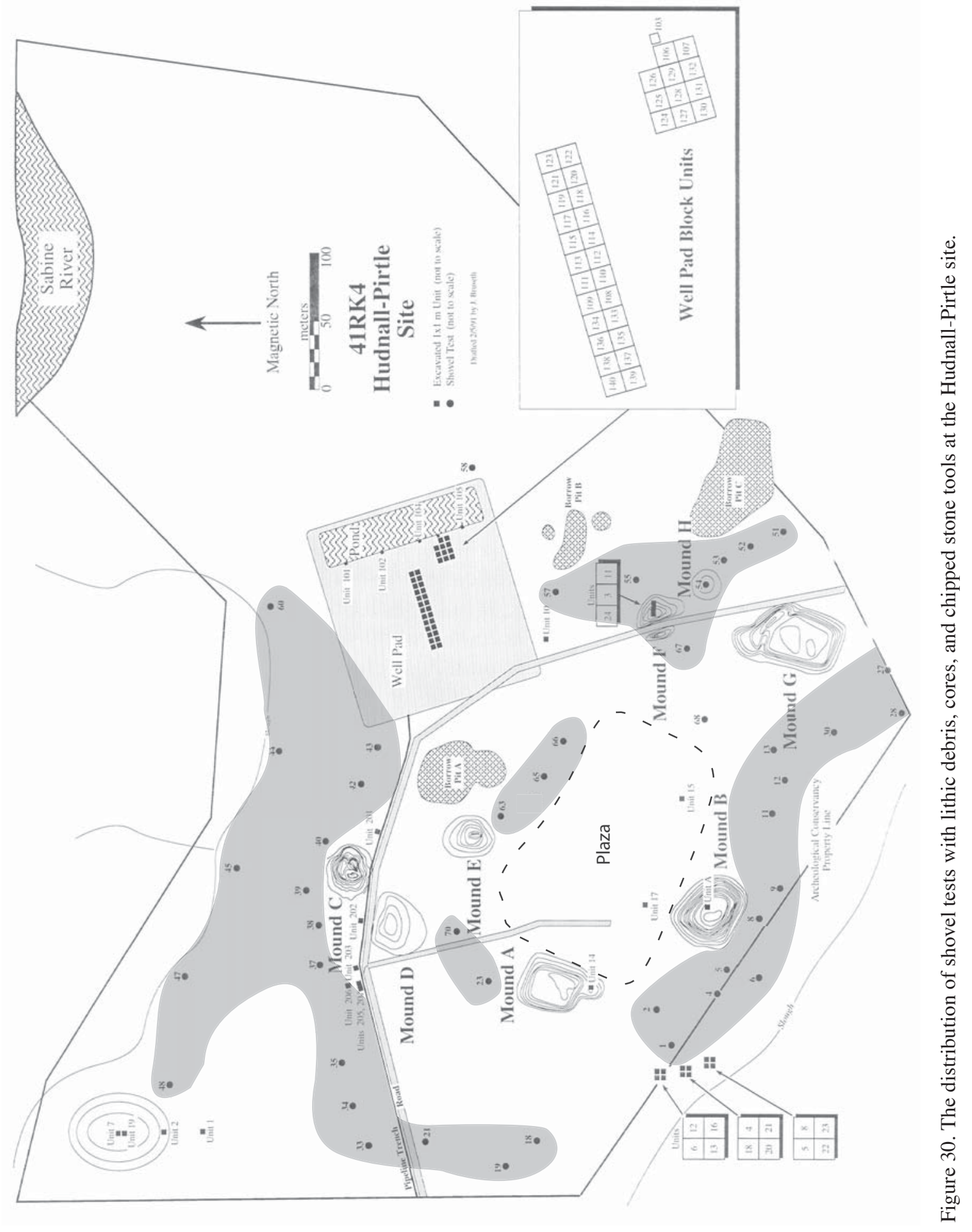




\section{Projectile Points}

A total of 93 projectile points were recovered from the 1989-1990 test excavations at the Hudnall-Pirtle site. Of the 93 points, only one is identified as a dart projectile point; the others have the size and shape consistent with their use as stone tips for a bow and arrow. Projectile points are common across the site, and were found in all proveniences except Mound F, where archeological materials were rather sparse in any case. They are particularly well represented in the Well Pad excavations, and in the Northwest Area of the site, where they account for between $25 \%$ and $38 \%$ of the stone tools from those areas, respectively. Almost $48 \%$ of the arrow points are fragmentary pieces (i.e., tips, blade mid-section, and stem fragments), apparently the broken fragments of once usable stone tips that were discarded in habitation areas, or were pieces that had become embedded in game animals that were returned to the site for butchering and processing.

Complete and/or near-complete projectile points were grouped into one dart point form class and 13 arrow point form classes. Important characteristics employed to segregate the projectile points includes hafting element (expanding, parallel, contracting, narrow-pointed, and bulbar), basal element (straight, convex, concave), body element (excurvate, incurvate, straight, and recurvate), margin element (none, serrated, upward pointing barbs), and shoulder element (none, barbed, squared, flared).

Dart Point Form $1(n=1)$

Provenience: WELL PAD, Surface

The one dart point is a Woodland period style Kent point (Figure 31a). It has a parallel hafting element and a slightly convex basal element, along with short and square shoulders. Kent points are generally found in Woodland period contexts in northeastern Texas (ca. 500 B.C. to A.D. 700), although not nearly to the same extent as contracting stem Gary dart points (see Rogers et al. 2001).

Arrow point Form $1(\mathrm{n}=1)$

Provenience: PIPELINE TRENCH: 201-1

The one arrow point form 1 piece is from an excavation unit along the pipeline trench near Mound. C (see Figure 2). It is a Hayes point, made and used after ca. A.D. 1200 in prehistoric Caddo sites, of a non-local chert. The point has a bulbar hafting element with a convex base and square shoulders.

Arrow point Form $2(\mathrm{n}=6)$

Provenience: WELL PAD: 108-1, 109-2, 119-1; SOUTHWEST AREA: 13-3, 18/20-5; NORTHWEST AREA: Shovel Test 34

This arrow point form is present in each of the three habitation areas investigated in 1990 at the Hudnall-Pirtle site. These points belong to the Early Caddoan period Catahoula type, and have broad parallel to expanding stems with distinctive flaring barbed shoulders (see Figure 31b-e and Figure 32n) and resharpened blades. Thirty-three percent of the Catahoula points are made from non-local chert, $50 \%$ are on local cherts, and one is made of a fine-grained Ogallala quartzite. Catahoula points are found widely in northeastern Texas Caddo sites (see Prewitt 1995:96). 


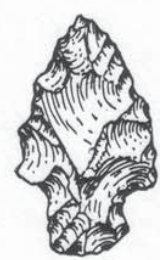

A

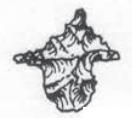

E
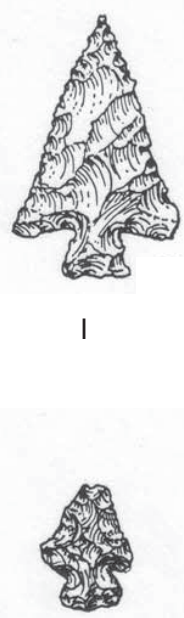

M

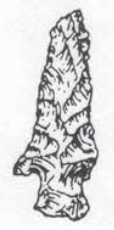

Q

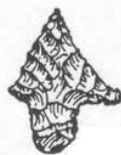

B

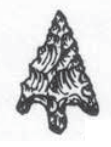

$\mathrm{F}$

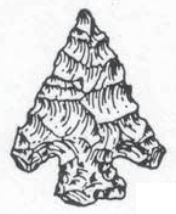

J

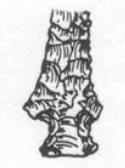

$\mathrm{N}$

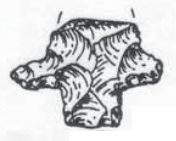

R
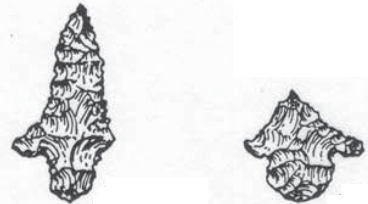

D

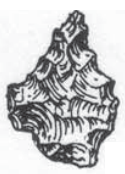

G

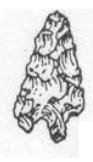

$\mathrm{H}$
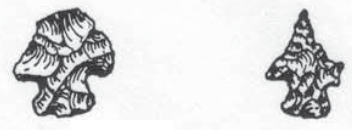

K

L

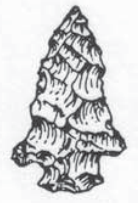

O

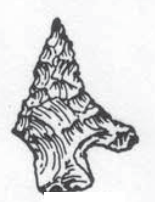

S

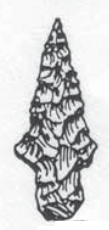

T

Figure 31. Dart Point Form 1 and Arrow Point Forms 1-9 at the Hudnall-Pirtle site: a, Kent point; b-e, arrow point form 2; $\mathrm{f}$, h, arrow point form 3; g, arrow point form 4; i-j, arrow point form 5; k-m, arrow point form 6 ; n-q, arrow point form 7; r-s, arrow point form 8; t, arrow point form 9. Provenience: a, Well Pad surface; b, Unit 13, lv. 3; c, ST 34; d, Unit 119, lv. 1; e, Unit 108, lv. 1; f, Unit 101, surface; g, Unit 13, lv. 2; h, Unit 116, lv. 2; i, Unit 13, 1v. 3; j, Unit 21, lv. 3; k, Unit 106, lv. 2; 1, Unit 134, lv. 3; m, Unit 133, lv. 2; n, Unit 23, lv. 2; o, Unit 107, lv. 2; p, Unit 107, lv. 3; q, Unit 131, lv. 2; r, Unit 5, lv. 2; s, Unit 21, lv. 4; t, Unit 117, lv. 2 . 
Arrow point Form $3(\mathrm{n}=2)$

Provenience: WELL PAD: 101-0, 116-2

The two arrow point form 3 points have narrow stems with flat bases, and small downward-pointing barbs. One with a parallel stem (see Figure 31f) may be an early version of a Perdiz point, although narrow-stemmed arrow points have been recovered in both Early and Middle Caddoan period sites in the Sabine and Angelina River basins in northeastern Texas (see Perttula and Nelson 2004). This point was made from a non-local chert. The other arrow point form 3 has a narrow contracting stem with small barbs, and may be a Bassett point (see Figure $31 \mathrm{~h}$ ); it is made of local chert. The Bassett point type has been documented in numerous Middle and Late Caddo sites in the general region of the Hudnall-Pirtle site. Thus, the recovery of the two arrow point form 3 points that resemble Perdiz and Bassett points suggests some use of the site after ca. A.D. 1200.

Arrow point Form $4(\mathrm{n}=2)$

Provenience: SOUTHWEST AREA: 13-2; PIPELINE TRENCH: 205-5

This arrow point form at the Hudnall-Pirtle site is comparable to the Friley type (see Figure $31 \mathrm{~g}$ ). These have broad contracting stems with a straight base, resharpened blades, and upward-projecting barbs or serrations on the blade. One of the Friley points is made of local chert, and the other is on a non-local chert. Friley arrow points appear to be one of the earliest arrow point styles in northeastern Texas and northwestern Louisiana, and their occurrence at Hudnall-Pirtle is further evidence (along with the recovery of the one Kent dart point) for use of some parts of the site in the latter part of the Woodland period. Such arrow points are believed to have been introduced around ca. A.D. 600/700. At the Browning site (41SM195A), for instance, Friley points were the only form recovered from a midden deposit that has a calibrated (2 sigma) radiocarbon date of AD 625-880 (Walters 2004).

Arrow point Form $5(\mathrm{n}=2)$

Provenience: SOUTHWEST AREA: 13-3, 21-3

The arrow point form 5 points are corner-notched points with broad expanding stems and rectangular barbs (Figure 31i-j), and they are identified as Scallorn points. Both are made from local cherts, and are the largest of the several different arrow point forms at the Hudnall-Pirtle site: 29.5 x 21 x 4 mm in mean length, width, and thickness. Scallorn arrow points are one of the earlier arrow point forms in use in northeastern Texas (ca. A.D. 700), and it continued to be used until ca. A.D. 1200. The occurrence of both the Friley and Scallorn points only in the Southwest Village area suggests that the earliest use, probably in Woodland period times, of the site took place in that part of the site.

Arrow point Form $6(n=4)$

Provenience: WELL PAD: 106-2, 133-2, 134-3; NORTHWEST AREA: 19-4

This arrow point form is a small-corner notched point, with a convex base and an expanding stem (see Figure 31k-m). These are Homan points, an Early Caddo arrow point type, found in some quantity at other important 
Early Caddoan period mound centers (see Webb and McKinney 1975). Three of the four Homan points are made from local cherts, and the other is on a fine-grained quartzite. In northeastern Texas, Homan arrow points are not apparently common on Caddo sites (cf. Prewitt 1995:111), but Turner and Smith (2003:65) note the recovery of Homan points in an Early Caddoan period component at the Harold Williams site (41CP10) in Camp County, Texas, and Homan points are present in large caches of arrow points in a Early Caddoan period shaft tomb at the Boxed Springs (41UR30) mound center on Big Sandy Creek in the Sabine River basin (Perttula et al. 2000:Figures 13-16).

Arrow point Form 7 (n=5)

Provenience: WELL PAD: 107-2, 107-3, 131-2; SOUTHWEST AREA: 12-5, 13-2

The arrow point form 7 points are Colbert points, which are related morphologically and chronologically to Homan points (see Webb 1963:180), another small expanding stem arrow point type that was made and used in the Early Caddoan period. The Colbert points at the Hudnall-Pirtle site have expanding stems, corner-notches with small barbs, and recurved blades (see Figure 31n-p). Sixty percent are made of local cherts, $20 \%$ from a finegrained quartzite, and one of the Colbert points from the Well Pad area was made of a non-local novaculite.

Arrow point Form $8(n=3)$

Provenience: WELL PAD: 109-2; SOUTHWEST AREA: 5-2, 21-4; NORTHWEST AREA: 7-5

This arrow point form is the first of four slightly different parallel-stemmed arrow points that are considered Alba, including arrow point forms 8-11. This Alba form has a parallel hafting element, a straight base, and flared barbs (see Figure 31r-s). The Alba point is the principal arrow point type in the Early Caddoan period occupation at the George C. Davis mound center (41CE19), where the type was first recognized and defined (Newell and Krieger 1949:161 and Figure 56a-h). It has a wide distribution on prehistoric Caddo sites in northeastern Texas (see Prewitt 1995:89), among them the Boxed Springs mound center in Upshur County, Texas. All three of the arrow point form 8 Alba points are made from local materials: local chert (67\%) and fine-grained quartzite $(33 \%)$.

Arrow point Form $9(n=7)$

Provenience: WELL PAD: 117-2, 118-1, 126-2; SOUTHWEST AREA: 4-1 (2), 20-3; NORTHWEST AREA: Uint 7-6

These Alba arrow points have parallel stems, flat to slightly convex bases, and shorter and rectangular-shaped barbs (see Figure 32a-b, see also Figure 31t). As with arrow point form 8, the blades on both forms have been recurved and resharpened through regular and repeated blade serrations. Shafer (2005:19) has noted that the Alba points at the George C. Davis site often have recurved blades and are often serrated.

About 57\% of these Alba points are made on local chert, compared to 14\% fine-grained quartzite and $14 \%$ petrified wood. One of the arrow point form 9 Alba points from the Well Pad area is made from novaculite. 


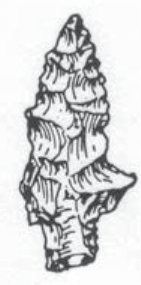

A

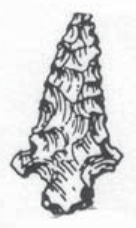

F

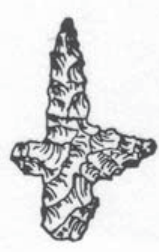

B

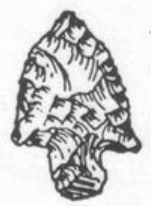

G

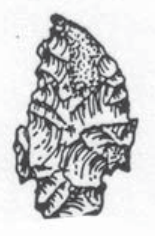

C

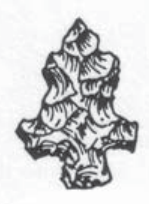

$\mathrm{H}$

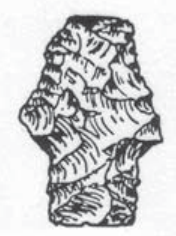

D

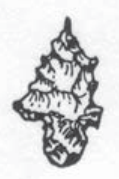

I

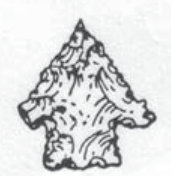

E

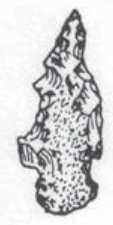

J

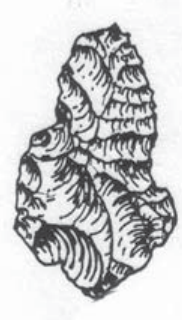

K

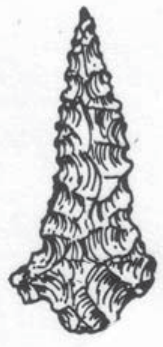

L

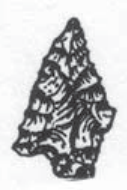

M

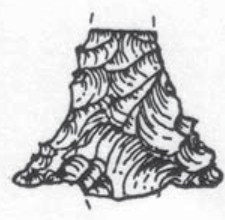

N

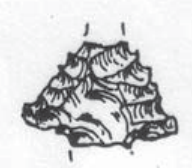

$\mathrm{O}$

Figure 32. Arrow point forms 2, 9-13 and unidentified forms: a-b, arrow point form 9; c-e, arrow point form 10; f-h, arrow point form 11; i-j, o, arrow point form 12; k-m, unidentified arrow point forms; 1 , arrow point form 13; n, arrow point form 2. Provenience: a, Unit 118, lv. 1; b, Unit 20, lv. 3; c, Unit 20, lv. 4; d, Unit 6, lv. 3; e, Unit 122, lv. 2; f, Unit 134, Fea. 103; g, Unit 12, lv. 3; h, Unit 119, lv. 2; i, Unit 138, lv. 2; j, Unit 118, lv. 1; k, Unit 18, lv. 4; 1, Unit 10, lv. 6; m, Unit 20, lv. 2;

Arrow point Form $10(n=4)$

Provenience: WELL PAD: 122-2, 138-2; SOUTHWEST AREA: 6-3, 20-4

The arrow point form 10 points have broader stems and blades than the other Alba point varieties at the Hudnall-Pirtle site (see Figure 32c-e). They also have smaller rectangular barbs than arrow point forms 8 and 9. Three of the four arrow point form 10 Alba points are made of quartzite-which is very different compositionally than all the other arrow point forms at the site - while one from the Well Pad area was made of novaculite. 
Arrow point Form $11(\mathrm{n}=6)$

Provenience: WELL PAD: 113-2, 119-2, 134-Feature 103; SOUTHWEST AREA: 12-3; NORTHWEST AREA: $7-4,19-4$

This arrow point form of the Alba type has a squarish-stem with a flat base, recurved blades, and rectangular barbs (see Figure 32f-h). These points are made exclusively from local lithic raw materials, including local chert $(67 \%)$ and fine-grained Ogallala quartzite $(33 \%)$.

Arrow point Form $12(\mathrm{n}=5)$

Provenience: WELL PAD: 118-1, 138-2; SOUTHWEST AREA: 6-2, 6-8, 7-5

Arrow point form 12 points belong to the Steiner type. They have rectangular to slightly expanding stems, small and upward-projecting barbs, and projecting spurs or barbs on the arrow point blade (see Figure 32i-j, o). A few Steiner points made from petrified wood were recognized in the Early Caddoan period component at the George C. Davis site (Newell and Krieger 1949:162, 164 and Figure 56o-q), and since then, they have been widely recovered in ca. A.D. 800-1200 Caddo components in northeastern Texas and farther west on non-Caddo sites in east central and north central Texas (see Prewitt 1995:131).

The Steiner arrow points from the Hudnall-Pirtle site are made from local lithic raw materials. This includes local chert (60\%) and fine-grained Ogallala quartzite (20\%); one of the points is made from a chert of unknown source.

Arrow point Form $13(\mathrm{n}=1)$

Provenience: NEAR WELL PAD: 10-6

The one arrow point form 13 specimen has a broad contracting stem and broad-rectangular shoulders and barbs (see Figure 32l); it is made from a non-local chert. The long blade has been resharpened. This particular form, were it not for the contracting stem, could well be assigned to the Catahoula type simply on the basis of the broad and somewhat flaring barbs. It is found in Unit 10 near the Well Pad (see Figure 2), and arrow point form 2 Catahoula points are also relatively common in this area of the Hudnall-Pirtle site.

Unidentified Form ( $\mathrm{n}=3)$

Provenience: SOUTHWEST AREA: 18-4, 20-2, 20-3

All three of the arrow points of unidentified form are from the Southwest Village area. They have contracting stems of various widths, with a convex base, and squared shoulders (see Figure 32k, m). One has a long and recurved blade (see Figure 32k), but with fractures along the basal margin. One other has a short stem with small barbs, and resembles other small contracting stem arrow points from Early Caddoan context (ca. A.D. 900-1000) at the Broadway site (41SM273) in the Angelina River basin (see Perttula and Nelson 2004:Figure 61d and Figure 62h).

Two of the unidentified arrow point forms are made on local chert, and the third is made from petrified wood. 
Arrow point Base Fragments $(\mathrm{n}=9)$

Provenience: WELL PAD: 123-2, Surface; SOUTHWEST AREA: 6-2, 13-2, 16-1; NORTHWEST AREA: 7-5, 7-7, 19-4; PIPELINE TRENCH: 202-1

The arrow point base fragments are found in various habitation areas at the Hudnall-Pirtle site, and each was presumably discarded in domestic contexts after an arrow point had been broken during use. One of the base fragments was made of a non-local chert, and others are made from fine-grained quartzite (44\%) and local chert (33\%); one other was made of a chert from an unknown source.

Arrow point Mid-section/Blade $(\mathrm{n}=12)$

Provenience: WELL PAD: 113-2, 120-2; SOUTHWEST AREA: 4-1, 4-3, 6-4, 6-7, 13-3, 18-1, 23-1, 23-2; NORTHWEST AREA: 19-4; NEAR MD. G: Shovel Test 30

The 12 arrow point mid-section/blade fragments are found predominately in the Southwest Village area (67\%), and all are made of apparently local lithic raw materials, including local chert (33\%) and fine-grained quartzite $(33 \%)$; the remainder are on cherts from unknown sources.

Arrow point Tip (n=20)

Provenience: WELL PAD: 10-8, 107-3, 107-4, 112-1 (2), 120-2, 122-2, 126-2, 133-1, 133-2, 136-2, 139-1; SOUTHWEST AREA: 6-2, 6-4, 8-1, 13-3; NORTHWEST AREA: 19-1, 19-3; MD. A: 14-9; MD. H: Shovel Test 54

Arrow point tips are particularly common in the Well Pad excavations (60\%). Only two (10\%) are made from non-local lithic raw materials (non-local chert in the Md. A specimen and novaculite in the arrow point tip from Unit 136 in the Well Pad area), while most of the remainder are on local cherts and quartzite.

\section{Summary of the Arrow points}

There is a good bit of formal diversity in the arrow point styles at the Hudnall-Pirtle site, and 10 different arrow point types are recognized in the chipped stone tool assemblage. About 13\% of the arrow points and arrow point fragments are made from non-local lithic raw materials, including novaculite and various non-local cherts; no Manning Formation lithic materials (i.e., baked tuff and Manning Fused Glass) were represented in the arrow point assemblage from the site.

The three main habitation areas (Well Pad, Southwest Village, and Northwest area) each have examples of the main arrow point types-Catahoula, Alba, and Steiner-and it seems to be the case that these habitation areas were occupied contemporaneously in the Early Caddoan period (ca. A.D. 1000-1200, and perhaps slightly earlier). Alba points comprise almost $42 \%$ of the typeable arrow points, followed by Catahoula (12.5\%), Steiner (10.4\%), and Colbert (10.4\%) types; the Colbert points are absent from the Northwest area. An earlier use of the Hudnall-Pirtle site (i.e., before A.D. 900) may be marked by the 
recovery of a few Friley and Scallorn arrow points from the Southwest Village area, while single possible examples of Perdiz and Bassett points from the Well Pad area hint of limited use of the site sometime after ca. A.D. 1200.

\section{Other Bifacial Tools}

There are 39 other bifacial tools in the stone tool assemblage from the Hudnall-Pirtle site. Included in the other bifacial tools are bifacial tool fragments, unidentified bifacial fragments from pieces that appear to have been completed, thick bifaces or preforms, arrow point preforms, and large hafted bifaces.

Bifacial Tool Fragments $(\mathrm{n}=10)$

Provenience: WELL PAD: 10-15, 106-7, 118-2, 135-2, 138-2; SOUTHWEST AREA: 4-5, 5-2, 12-5, 16-2, 18-3

The bifacial tool fragments are the remnants of various-sized completed bifacial tools (Figure 33e and Figure 34a). Only one of the tool fragments has cortical remnants and $60 \%$ have obvious signs of either unifacial or bifacial use wear. These tools are probably broken pieces of formal hafted tools of different sorts. Thirty percent of the bifacial tool fragments are made from a fine-grained quartzite, and a similar percentage is on local cherts. Other lithic raw materials include petrified wood (10\%) and novaculite (10\%); $20 \%$ are on cherts from unknown sources.

The bifacial tool fragments average $21.2 \mathrm{~mm}$ in width and $5.1 \mathrm{~mm}$ in thickness, although two of them (both with use-wear) are slightly larger and thicker hafted tools, with a mean thickness of $7.5 \mathrm{~mm}$.

Unidentified Bifacial Fragments ( $=9$ )

Provenience: WELL PAD: Surface, 119-2, 121-2; SOUTHWEST AREA: 8-1, 12-5, 16-6, 18-6; NORTHWEST AREA: 7-6; PIPELINE TRENCH: 0-0-377 (trench monitoring)

The unidentified bifacial fragments are not from completed tools, as none of them have any evidence of use-wear and 33 percent still have cortical remnants on one or both faces. They are an average of $20.1 \mathrm{~mm}$ in width and $5.9 \mathrm{~mm}$ in thickness, not much different than the hafted bifacial tools, but $3.5 \mathrm{~mm}$ thinner than the thick bifaces or bifacial preforms. The unidentified bifacial fragments apparently represent broken and discarded bifaces that were being manufactured on site, and were nearing completion when they were broken.

More than 55\% of the unidentified bifacial fragments are on local quartzites, particularly the fine-grained Ogallala quartzite ( $\mathrm{n}=4$ pieces). Two other fragments are on local cherts, a third is made from hematite, and one other is on chert from an unknown source.

Thick Bifaces or Preforms $(\mathrm{n}=8)$

Provenience: WELL PAD: 108-1, 136-1, Surface; SOUTHWEST AREA: 6-5, 8-1, 16-4 (2); NORTHWEST AREA: 7-5; PIPELINE TRENCH: 202-9 

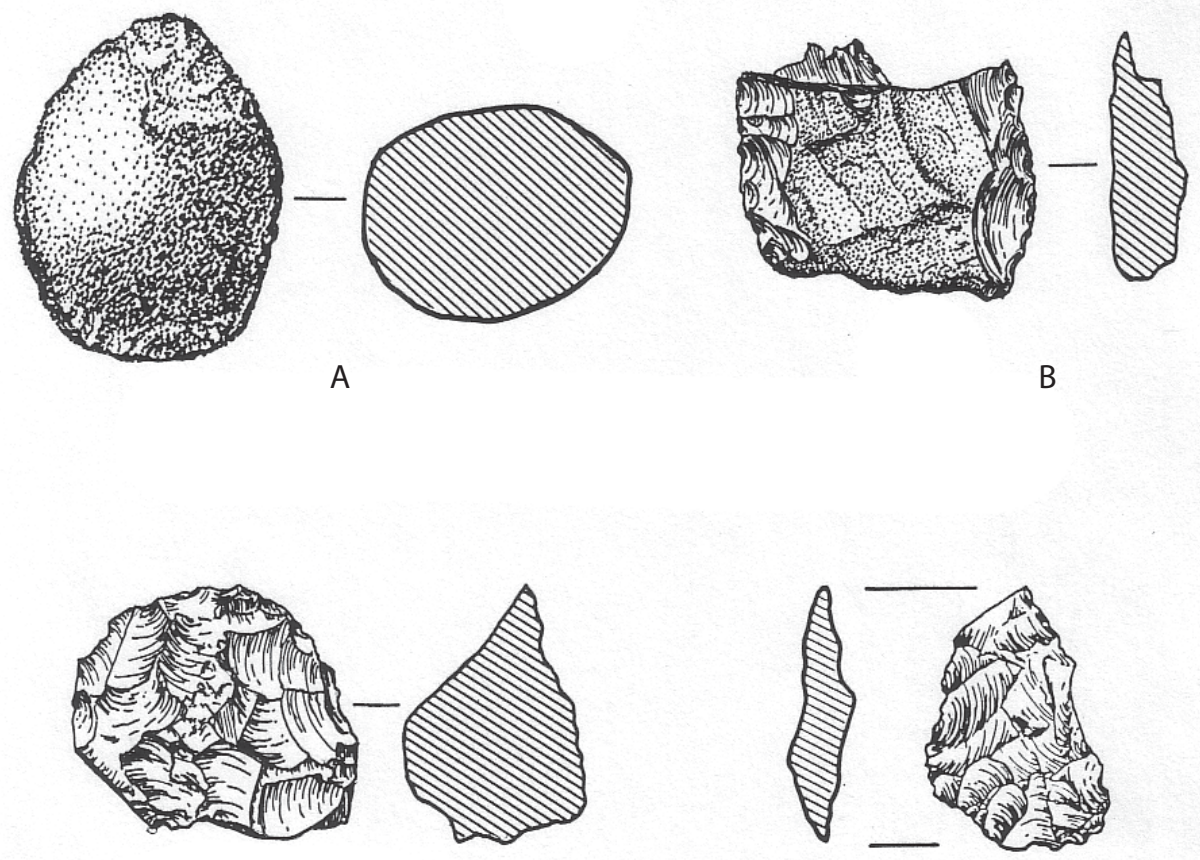

C

D
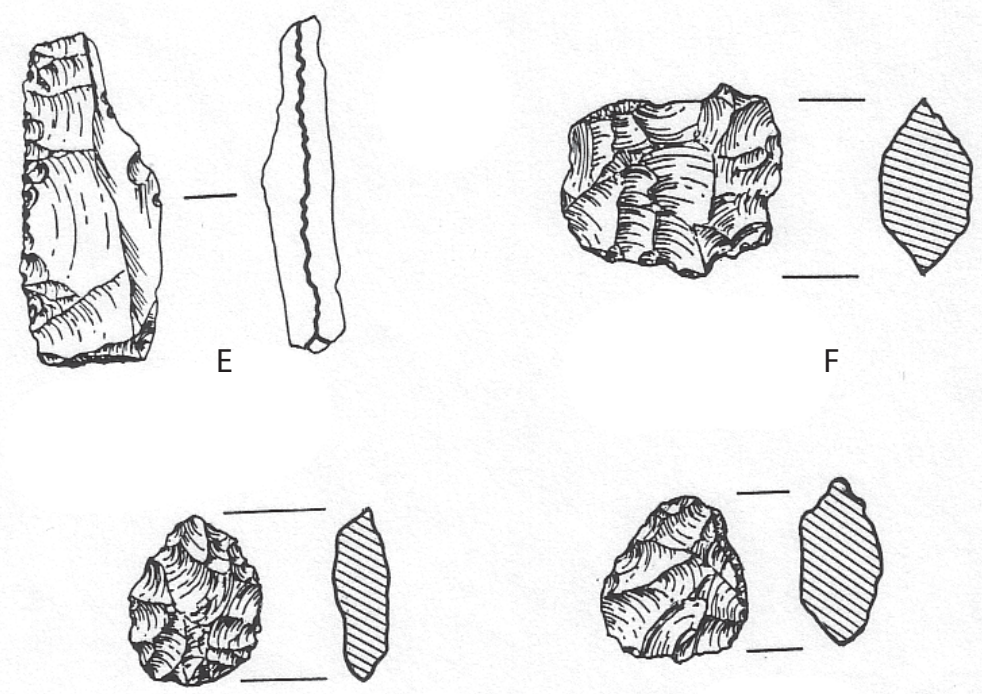

G

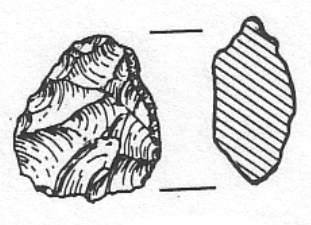

$\mathrm{H}$

Figure 33. Bifacial tools and preforms and other lithic artifacts: a, hammerstone; b, f, h, biface preform; c, bifacial core; d, g, arrow point preform; e, bifacial tool fragment. Provenience: a, Unit 20, lv. 4; b, Unit 108, lv. 1; c, Unit 135, lv. 2; d, Unit 18/20, lv. 5; e, Unit 12, lv. 5; f, Unit 7, lv. 5; g, Unit 106, lv. 4; h, Unit 6, lv. 5. 

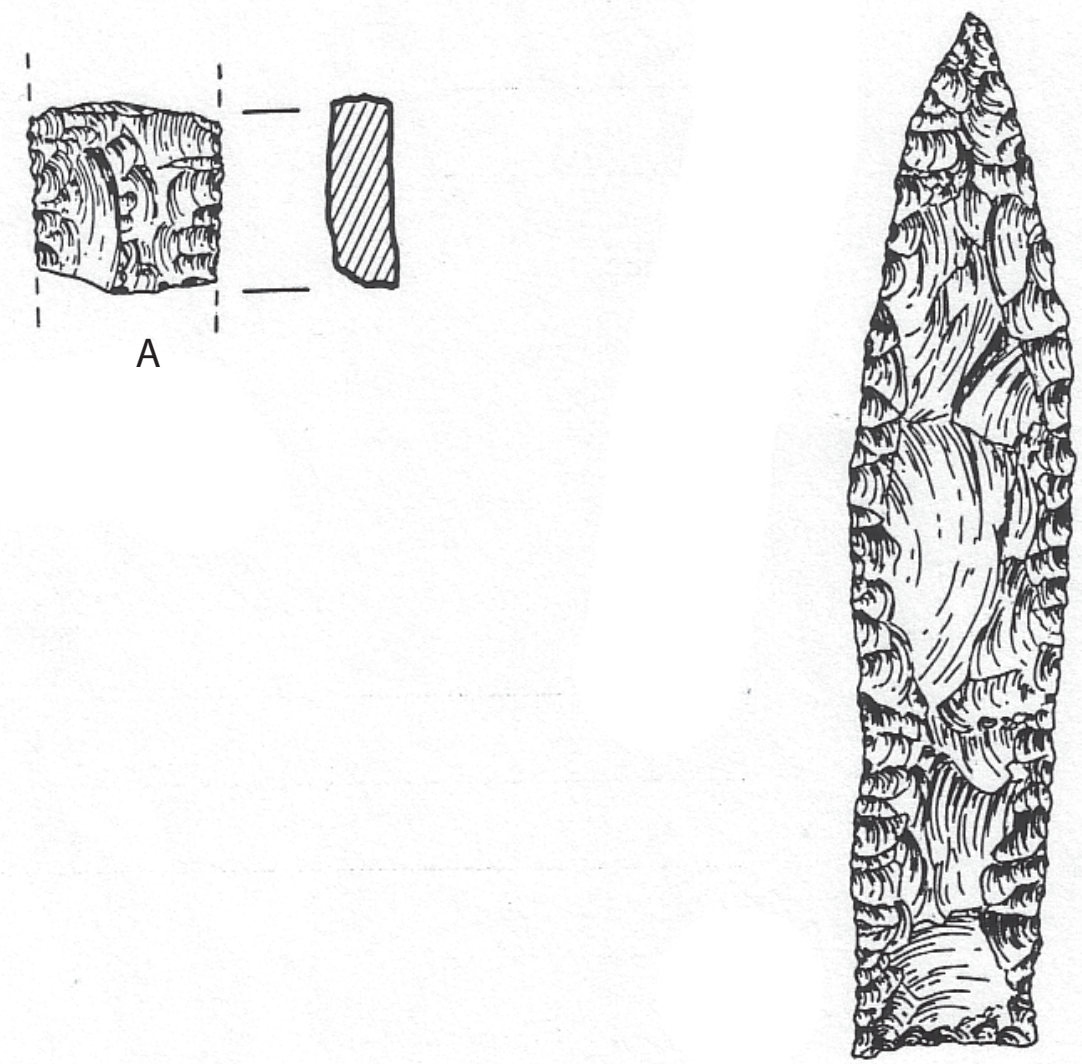

B

Figure 34. Hafted bifacial tools: a, bifacial tool fragment; b, hafted biface, Gahagan biface. Provenience: a, Unit 16, lv. 2; b, Pipeline trench near Md. C.

The eight thick bifaces (mean thickness of $9.4 \mathrm{~mm}$ ) from the Hudnall-Pirtle site are preforms rather than finished tools, and were shaped using a combination of hard hammer and soft hammer flaking (see Figure 33b, f, and h). Fifty percent of the preforms still have cortical remnants, and only $22 \%$ have not been broken during manufacture. The two complete preforms are oval-shaped, and small in size (24-28 mm in length and 20-22 $\mathrm{mm}$ in thickness), but still rather thick in cross-section (see Figure 33f, h), suggesting they may have been intended for use as arrow points but could not be further thinned before they were discarded.

Half of the preforms were made from petrified wood. Another $25 \%$ were made of local quartzite, one other was made of local chert, and the final thick biface was made of a Manning Formation chert with a pink-colored cortex.

Arrow point Preforms $(\mathrm{n}=10)$

Provenience: WELL PAD: 106-4, 113-2, 123-2, 135-2; SOUTHWEST AREA: 4-1, 4-5, 18/20-5; NORTHWEST AREA: 7-8, 19-4; MD. A: 14-1 
The arrow point preforms are bifacially-chipped ovoid-shaped tools (see Figure 33d, g) that were eventually meant, upon the shaping of a stem, for use on stone-tipped bow and arrows. Their recovery in various contexts at the Hudnall-Pirtle site indicates that arrow points were commonly manufactured by the Caddo inhabitants.

Only $40 \%$ of the arrow point preforms are not broken, and these average $23.5 \mathrm{~mm}$ in length, $14.3 \mathrm{~mm}$ in width, and $3.8 \mathrm{~mm}$ in thickness; none have any signs of use-wear. The broken arrow point preforms (including one with cortical remnants) are considerably wider $(18.3 \mathrm{~mm})$ and thicker $(5.2 \mathrm{~mm})$ than the completed preforms, suggesting they were broken during their attempted thinning and shaping.

Forty percent of the arrow point preforms are made from a fine-grained Ogallala quartzite, and $30 \%$ are of local cherts. Two others are made from petrified wood and a chert from an unknown source. One of the preforms is made of novaculite.

Hafted Bifaces $(n=2)$

Provenience: PIPELINE TRENCH: 0-0-263, 0-0-380

The two hafted bifaces were found during the monitoring of the pipeline trench near Md. C. Both are large and expertly-chipped hafted tools (see Figure 34b) made from non-local chert, in this case a dark brown Edwards chert from the Central Texas region; the hafted bifaces were likely made in the Central Texas region and traded to the Caddo. The blade on the one complete hafted biface is slightly re-curved, perhaps to facilitate hafting, and the base is also only slightly concave (see Figure 34b); there is use-wear on the blade, probably from use in cutting/sawing fairly durable materials. It is $103 \mathrm{~mm}$ in length, $23 \mathrm{~mm}$ in width, and only $5 \mathrm{~mm}$ thick.

The two hafted bifaces from the Hudnall-Pirtle site are probably Gahagan bifaces (see Shafer 1973:224-231 and Figure 19a-v). The one complete specimen is about the same mean length and thickness as the Gahagan bifaces from the George C. Davis site, but considerably narrower in width; the mean blade width on the George C. Davis Gahagan bifaces is $36 \mathrm{~mm}$ (Shafer 1973:229).

\section{Unifacial Tools}

Unifacial chipped stone tools are the most common type of stone tools at the Hudnall-Pirtle site. The 164 unifacial stone tools from the site comprise approximately $41 \%$ of the total tool assemblage. The well pad excavations recovered the largest proportional sample, as $50 \%$ of the 154 stone tools from this area were identified as unifacial tools.

The edge-modified piece is the dominant unifacial tool in the assemblage $(n=109)$, accounting for $66.5 \%$ of the sample. Retouched or shaped pieces (11.6\%), and edge-modified piece/gravers (6.1\%) are also well represented at the Hudnall-Pirtle site. About $20 \%$ of the unifacial tools are made on non-local lithic raw materials, including novaculite (4.3\%), Manning Formation cherts and baked tuff (2.4\%), and various non-local cherts (14.0\%). Of the different unifacial tool types with more than one specimen, the edge-modified pieces have the highest proportion of non-local lithic raw materials at $24.8 \%$, followed by $15.8 \%$ for retouched pieces.

Edge-modified piece $(\mathrm{n}=109)$ 
Provenience: WELL PAD: 10-6, 10-11, 101-ALL, 102-0-6 (2), 103-0-7, 106-2, 107-2, 108-1, 108-2B, 109-2, 110-1, 110-2, 112-2, 113-1 (2), 114-1, 114-2, 115-2 (3), 116-1, 116-2 (3), 118-1, 118-2, 119-1, 119-2 (2), 1201, 120-2, 121-1, 122-1, 123-2 (2), 124-2, 125-2, 125-4 (2), 126-2, 126-3, 127-2, 129-2, 133-2, 135-1, 135-2, 136-2, 137-2 (3), 138-2 (3), 139-3 (2), 140-2; SOUTHWEST AREA: 4-6, 4/18/20/21-6, 5-3, 6-2, 6-4, 8-1 (2), 12-1 (2), 12-3 (2), 12-5 (3), 13-1, 13-3 (4), 16-2 (3), 16-4, 16-6 (2), 18-3, 18/20-5 (2), 20-2, 20-3 (2), 20-4, 21-0, 21-2 (3), 21-4, 21-5, 22-2/3, 23-1 (2), 23-2 (2); NORTHWEST AREA: 7-6, 7-11; MD. A: 14-9, 14-11, 14-12; NEAR MD. B: Shovel Test 7, Shovel Test 8; PIPELINE MONITORING: 0-0-372

The edge-modified piece is a lithic flake or chip with an overlapping set of small flake removals or step fractures (Figure $35 \mathrm{~d}, \mathrm{f}, \mathrm{k}-\mathrm{l}, \mathrm{n}$ ) caused by use rather than intentional modification through shaping by retouch. Seven of the edge-modified pieces are on expediently produced blades (see Figure 35d-e, 1). The most common locations for use wear on these flake tools is either on one lateral edge (45\%, see Figure 35e) or on the distal flake edge (22\%). Another 12\% have bilateral use-wear (see Figure 35k), and $11 \%$ are edge-modified on distal and lateral edges. About 5.5\% have alternate retouch (see Figure 35d), and the remainder (4.6\%) have both distal and bilateral use-worn areas (see Figure 35n).

Almost $46 \%(n=50)$ of the edge-modified pieces are on local cherts, and $11 \%$ are on local quartzite raw materials; $3.7 \%$ are on petrified wood, and $0.9 \%$ are on hematite. Other common local lithic materials among the edge-modified pieces include chalcedony (11\%). Edge-modified pieces on non-local raw materials are relatively abundant, and include novaculite (6.4\%), various non-local cherts (15.6\%), and various materials from the Manning Formation (including Manning Fused Glass, baked tuff, and a chert with a thick pink cortex); the latter comprise $2.7 \%$ of the edge-modified pieces. Finally, $2.7 \%$ are on cherts from unknown sources.

Edge-modified piece/graver $(\mathrm{n}=10)$

Provenience: WELL PAD: 120-2, 128-2, 134-2, 135-2, 139-2, 140-1; SOUTHWEST AREA: 5-2, 13-1; NORTHWEST AREA: Shovel Test 34; MD. F: 11-2

Ten edge-modified pieces also have a graver tip (see Figure 35c, i); the graver tip is along the terminus of the area of edge modification/use-wear. These are along the lateral edges of the flake tool $(20 \%)$, as well as distal/bilateral (30\%, see Figure 35c), distal/lateral (20\%, see Figure 35i), bilateral (20\%), and alternate/distal $(10 \%)$. Sixty percent of the edge-modified/graver tools are on local cherts and $20 \%$ are on quartzite; the others are made from cherts from an unknown source.

Edge-modified piece/perforator $(\mathrm{n}=1)$

Provenience: WELL PAD: 133-2

One edge-modified flake tool also has a unifacially flaked perforator on its distal edge. The tool $(20 \times 7 \times 3$ $\mathrm{mm}$ in length, width, and thickness) is made from a non-local chert. The edge-modified portion of the piece has bilateral use-worn areas.

Retouched or shaped piece $(\mathrm{n}=19)$ 


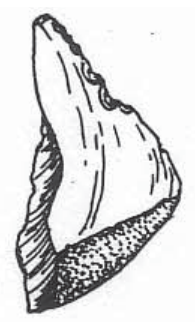

A

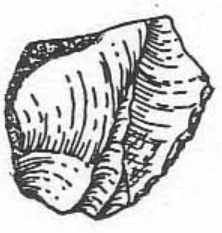

B

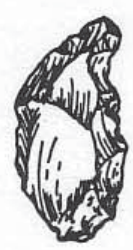

C

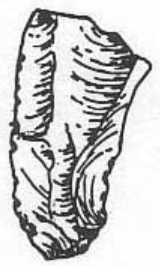

D

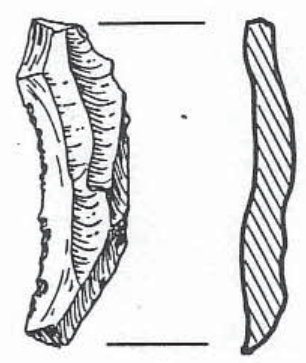

E

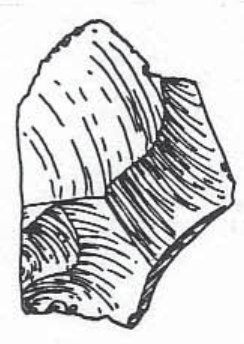

F

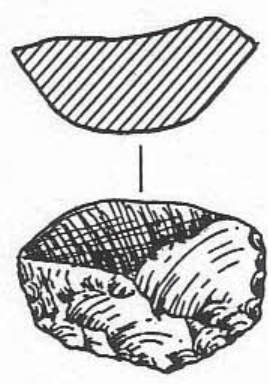

G

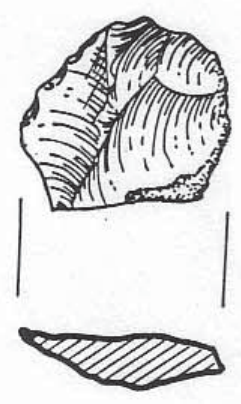

$\mathrm{H}$

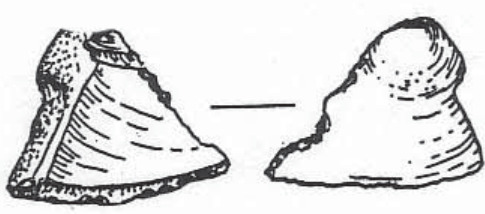

I

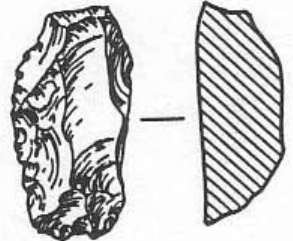

J

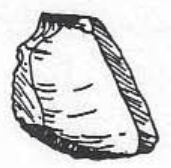

K

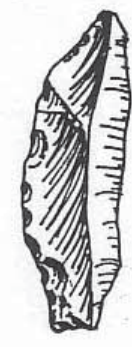

L

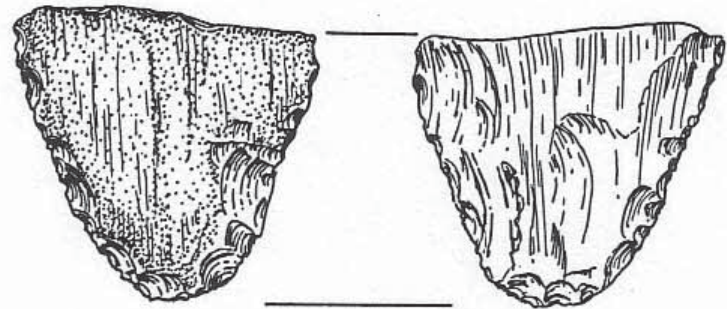

M

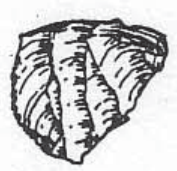

N

Figure 35. Unifacial tools from the Hudnall-Pirtle site: a, perforator; c, i, edge-modified piece/graver; d, f, k-l, n edgemodified piece; e, edge-modified piece/blade; g-h, j, retouched piece; m, side scraper. Provenience: a, Unit 6, lv. 2; c, Unit 128, lv. 2; d, Unit 21, lv. 2; e, Unit 13, lv. 3; f, Unit 21 surface; g, Unit 13, lv. 5; h, Unit 20, lv. 4; i, Unit 13, lv. 1; j, Unit 135, lv. 1; k, Unit 16, lv. 2; 1, Unit 21, lv. 5; m, Unit 4, lv. 5; n, Unit 136, lv. 2. 
Provenience: WELL PAD: 106-2, 109-2, 114-1, 115-2, 118-2, 120-1, 137-2; SOUTHWEST AREA: 4-4, 4-5, 6-4, 8-1, 18-3, 20-3, 20-4 (2), 21-5; NORTHWEST AREA: 7-13; NEAR MD. G: Shovel Test 28; PIPELINE MONITORING: 0-0-376

The retouched pieces are flake tools with deliberately shaped working edges; the edges are shaped by careful unifacial pressure flaking (see Figure 35g-h, j). Most of the retouched pieces have distal retouch (37\%, see Figure $35 \mathrm{~h}$ ), suggesting use in scraping/shaving tasks, along with lateral (26\%), bilateral (16\%, see Figure 35g, j), distal and lateral (11\%), and alternate retouch (5\%); the latter tool was on a blade.

More than $10 \%$ of the retouched pieces are on non-local chert, and one other is on a Manning Formation chert with a thick pink cortex. Almost 32\% are made from local chert; $16 \%$ are on quartzite; $11 \%$ are on petrified wood; $21 \%$ are on chalcedony; and one retouched piece is made from a chert of unknown source. The retouched pieces range in size from 16-48 $\mathrm{mm}$ in length, 11-40 $\mathrm{mm}$ in width, and 2-10 $\mathrm{mm}$ in thickness. Four of the retouched pieces are distinctly larger in size than the others (i.e., mean length of $34.8 \mathrm{~mm}$, mean width of $25.0 \mathrm{~mm}$, and $8.5 \mathrm{~mm}$ thick), and have more effective retouched and use-worn areas than the much smaller retouched pieces.

Perforator $(n=3)$

Provenience: WELL PAD: 118-2; SOUTHWEST AREA: 6-2, 18-3

The unhafted perforating tools have unifacially chipped projections or bits (Figure 36b; see also Figure 35a), on flakes, that would have been useful in piercing and punching various durable materials, such as hides or wood. They are made on local cherts, and range from 21-32 mm in length, 10-22 mm in width, and 2-6 mm in thickness along the unifacial bit.

Graver $(\mathrm{n}=2)$

Provenience: SOUTHWEST AREA: 6-4, 18-4

The graving tools have small projections on either lateral or distal edges of otherwise unmodified flakes. Both of the gravers from the Hudnall-Pirtle site are made on local cherts. The tools are 16-18 mm in length, 10-11 $\mathrm{mm}$ in width, and 2-3 $\mathrm{mm}$ in thickness.

Drill $(\mathrm{n}=2)$

Provenience: WELL PAD: 138-2; SOUTHWEST AREA: 20-4

The two bifacially-chipped drills (see Figure 36a) are from habitation areas at the Hudnall-Pirtle site. Both drills have use-wear along distal and bi-lateral edges of the flake tools, and they are made on a coarse-grained quartzite and a local chert. They range from 13-27 $\mathrm{mm}$ in length, 13-16 $\mathrm{mm}$ in width, and they are $4 \mathrm{~mm}$ thick along the drill bit. 


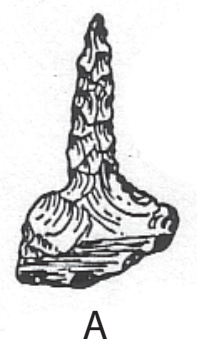

A

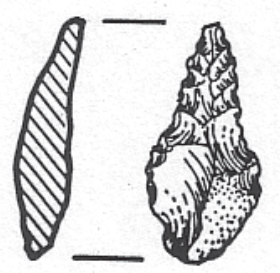

B

Figure 36. Drill and perforator from the Hudnall-Pirtle site: a, drill; b, perforator. Provenience: a, Unit 20, lv. 4; b, Unit 118, lv. 2 .

Denticulate $(\mathrm{n}=5)$

Provenience: WELL PAD: 114-1; SOUTHWEST AREA: 4-6, 6-4, $8-1,12-5$

Five flake tools-mostly from habitation contexts in the Southwest Village area-have an irregular serrated or denticulated working edge. The area(s) of modification includes lateral (40\%), bilateral $(20 \%)$, distal (20\%), and distal/bilateral (20\%). The distally worked denticulate is made from a non-local chert, while the others are all made from local cherts. In size, the denticulates range from 10-21 $\mathrm{mm}$ long, 6-13 $\mathrm{mm}$ wide, and 2-5 $\mathrm{mm}$ thick.

End Scraper $(\mathrm{n}=6)$

Provenience: WELL PAD: 111-2 (3), 114-2; SOUTHWEST AREA: $4-3,21-5$

The end scrapers have steep chipped working edges along the distal edges of the tool; the working edge is unifacial and the remainder of the flake tool is only marginally retouched, probably because these tools were not hafted. The end scrapers were made of fine-grained quartzite $(n=2)$, local chert $(n=1)$, non-local chert $(n=1)$, Manning Formation chert $(\mathrm{n}=1)$, and a chert from an unknown source. These tools are $16-30 \mathrm{~mm}$ in length, $13-28 \mathrm{~mm}$ in width, and 3-8 $\mathrm{mm}$ in thickness; the range in size and thickness suggests that the Caddo peoples at Hudnall-Pirtle may have been using two different sizes of end scrapers in various scraping tasks.

Side Scraper $(n=5)$

Provenience: WELL PAD: 137-2; SOUTHWEST AREA: 6-5, 12-3, 21-2; NORTHWEST AREA: 7-7

The side scraping tools have retouched edges with evidence of use-wear along one or more lateral edges of variously-shaped flakes (see Figure $35 \mathrm{~m}$ ); none are obviously hafted tools. Sixty percent are made on either fine-grained Ogallala quartzite or coarse-grained quartzite, another is on chalcedony, and one is on a non-local chert; the more durable nature of the quartzite raw material would be well-suited to heavy-duty scraping of hides. The side scrapers range from $18-23 \mathrm{~mm}$ in length, $10-17 \mathrm{~mm}$ in width, and 2-6 $\mathrm{mm}$ thick.

End/Side Scraper $(n=1)$

Provenience: SOUTHWEST AREA: 13-5 
The one end-side scraping tool has steeply retouched and use-worn areas along both distal and lateral edges of a medium-sized and otherwise unmodified flake of coarse-grained quartzite. The tool is $24 \times 21 \times 9 \mathrm{~mm}$ in length, width, and thickness.

End Scraper/Graver $(\mathrm{n}=1)$

Provenience: SOUTHWEST AREA: 18/20-5

One of the end scrapers from the site also has a graver spur on the distal working edge of the tool. It is made from a local chert, and measures $14 \times 18 \times 5 \mathrm{~mm}$ in length, width, and thickness.

\section{Ground stone Tools}

The majority of the 14 ground stone tools from the Hudnall-Pirtle site were recovered in the test excavations in the Well Pad ( $n=5)$ and Southwest Village areas $(n=6)$. Single ground stone tools were also found in the Northwest area of the site, in Mound A, and in the vicinity of Mound C during trench monitoring. Eight different types of ground stone implements have been identified in the small assemblage, including (in the order of their frequency): grinding slabs, mano/pitted stones (single pitted facet), mano/pitted stones (multiple pitted facets), hammerstone, celts, paint palette, pitted stone (multiple facets), and an abrader.

Grinding Slabs $(\mathrm{n}=4)$

Provenience: WELL PAD: 103-1, 132-2; SOUTHWEST AREA: 12-3; Trench Monitoring in vicinity of Md. C

Grinding slabs are flat slabs of locally available ferruginous sandstone or hematite that have been worn on one or both sides of the slab during the grinding and/or pulverizing of plant materials (including seeds) to create a smooth surface that ranges from flat to dish-shaped across the majority of the slab surface. Only one of the grinding slabs is complete (from the Southwest Village area), and it is $119 \mathrm{~mm}$ in length, $62 \mathrm{~mm}$ in width, and $12 \mathrm{~mm}$ in thickness. With the exception of the $36 \mathrm{~mm}$ thick grinding slab from Unit 103 at the Well pad (1031-266), the other fragmentary slabs range between 6 and $12 \mathrm{~mm}$ in thickness.

Mano/Pitted Stone (single pitted facet) $(\mathrm{n}=2)$

Provenience: SOUTHWEST AREA: 8-1, 12-2

These ground stone tools were multi-functional implements shaped by pecking from cobble-sized pieces of ferruginous sandstone. Both tools have flat and well-worn facets on both sides of the cobble where they had been worn down from grinding abrasive materials (i.e., seeds and other plant materials) on a larger slab, and the edges appear to have also been used for pounding actions. A single small circular depression or pit occurs on one facet of the manos. 
Mano/Pitted Stone (multiple facets with pits) $(n=2)$

Provenience: WELL PAD: Surface; SOUTHWEST AREA: Shovel Test 1

Two ferruginous sandstone manos have small circular depressions or pits on both faces of the tool (Figure 37b). Both faces had also been well-ground from use on a larger slab. The two mano/pitted stone tools range from $75-127 \mathrm{~mm}$ in length, $69-113 \mathrm{~mm}$ in width, and $42-49 \mathrm{~mm}$ in thickness, and are quite a bit larger than the mano/single pitted stone (i.e., 41-71 $\mathrm{mm}$ in length, 40-62 $\mathrm{mm}$ in width, and 16-39 $\mathrm{mm}$ in thickness), suggesting the mano/pitted stone tool classes were put to different uses by the Caddo peoples at the Hudnall-Pirtle site. Perhaps the small mano/pitted stone tools were used to more frequently grind seeds, while the larger mano/pitted stones with multiple pits were used to grind seeds, other plant materials such as maize, and also repeatedly crush hickory and pecan nutshells.

Hammerstone $(\mathrm{n}=1)$

Provenience: SOUTHWEST AREA: 20-4

The hammerstone is made from a piece of coarse-grained quartzite (see Figure 33a). It has crushing marks and irregular flake removals on both end of the cobble, the result of striking resistant lithic materials in the process of core and tool reduction activities. Most of the surface of the $43 \mathrm{~mm}$ long hammerstone is covered with cortex.

Celt $(n=2)$

Provenience: MD. A: 14-10; WELL PAD, no provenience

The first celt came from occupational deposits in $1 v .10$ (90-100 cm bs), immediately beneath Mound A mound fill. The celt fragment ( $23 \mathrm{~mm}$ thick) was made from hematite and had been well polished on all surfaces (see Figure 37c). It apparently was broken during use rather than manufacture-given the finished appearance of the tool-and discarded in a habitation area that was eventually covered by the construction of the Mound A platform.

The second celt is a large hematite celt recovered from the Well Pad area, although its specific provenience is not known. This celt (Figure 38) was smoothed to polished on both surfaces (although the surface is cortex), and there are hard hammer flake scars on both faces, evidence of the shaping of the hematite cobble.

The bit on the celt is polished and bifacial, with a bit width of $69.0 \mathrm{~mm}$, and a bit length (i.e., the extent of polishing on the tool's surface at the bit itself) ranges from 11.8-25.1 $\mathrm{mm}$. There is discontinuous polish on both surfaces that extend a few $\mathrm{mm}$ farther down the tool's face. The celt is $140.0 \mathrm{~mm}$ in length, $73.6 \mathrm{~mm}$ wide, and $35.8 \mathrm{~mm}$ thick.

Paint Palette (n=1)

Provenience: WELL PAD: 118-1 

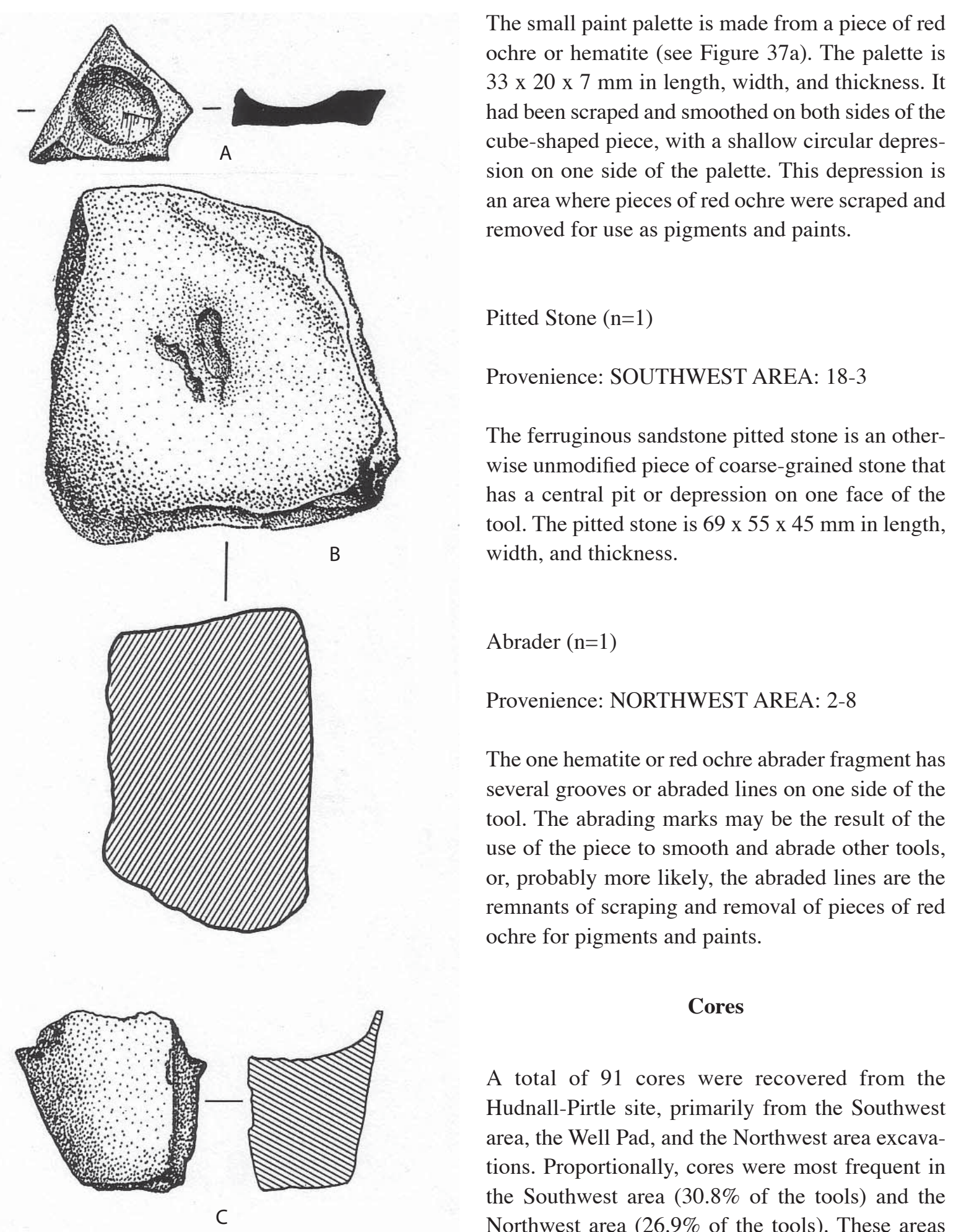

Figure 37. Ground stone tools from the Hudnall-Pirtle site: a, paint palette; $b$, mano/pitted stone; $c$, celt fragment. Provenience: a, Unit 118, lv. 1; b, ST 1; c, Unit 14, lv. 10.
Pitted Stone $(n=1)$

Provenience: SOUTHWEST AREA: 18-3

The ferruginous sandstone pitted stone is an otherwise unmodified piece of coarse-grained stone that has a central pit or depression on one face of the tool. The pitted stone is $69 \times 55 \times 45 \mathrm{~mm}$ in length, width, and thickness.

Abrader ( $\mathrm{n}=1)$

Provenience: NORTHWEST AREA: 2-8

The one hematite or red ochre abrader fragment has several grooves or abraded lines on one side of the tool. The abrading marks may be the result of the use of the piece to smooth and abrade other tools, or, probably more likely, the abraded lines are the remnants of scraping and removal of pieces of red ochre for pigments and paints.

\section{Cores}

The small paint palette is made from a piece of red ochre or hematite (see Figure 37a). The palette is $33 \times 20 \times 7 \mathrm{~mm}$ in length, width, and thickness. It had been scraped and smoothed on both sides of the cube-shaped piece, with a shallow circular depression on one side of the palette. This depression is removed for use as pigments and paints.

A total of 91 cores were recovered from the Hudnall-Pirtle site, primarily from the Southwest area, the Well Pad, and the Northwest area excavations. Proportionally, cores were most frequent in the Southwest area (30.8\% of the tools) and the Northwest area (26.9\% of the tools). These areas typically also have the highest densities of lithic debris and bifacial tools (especially broken tools and thick bifaces/preforms), which appears to indicate that the on-site production of chipped stone 


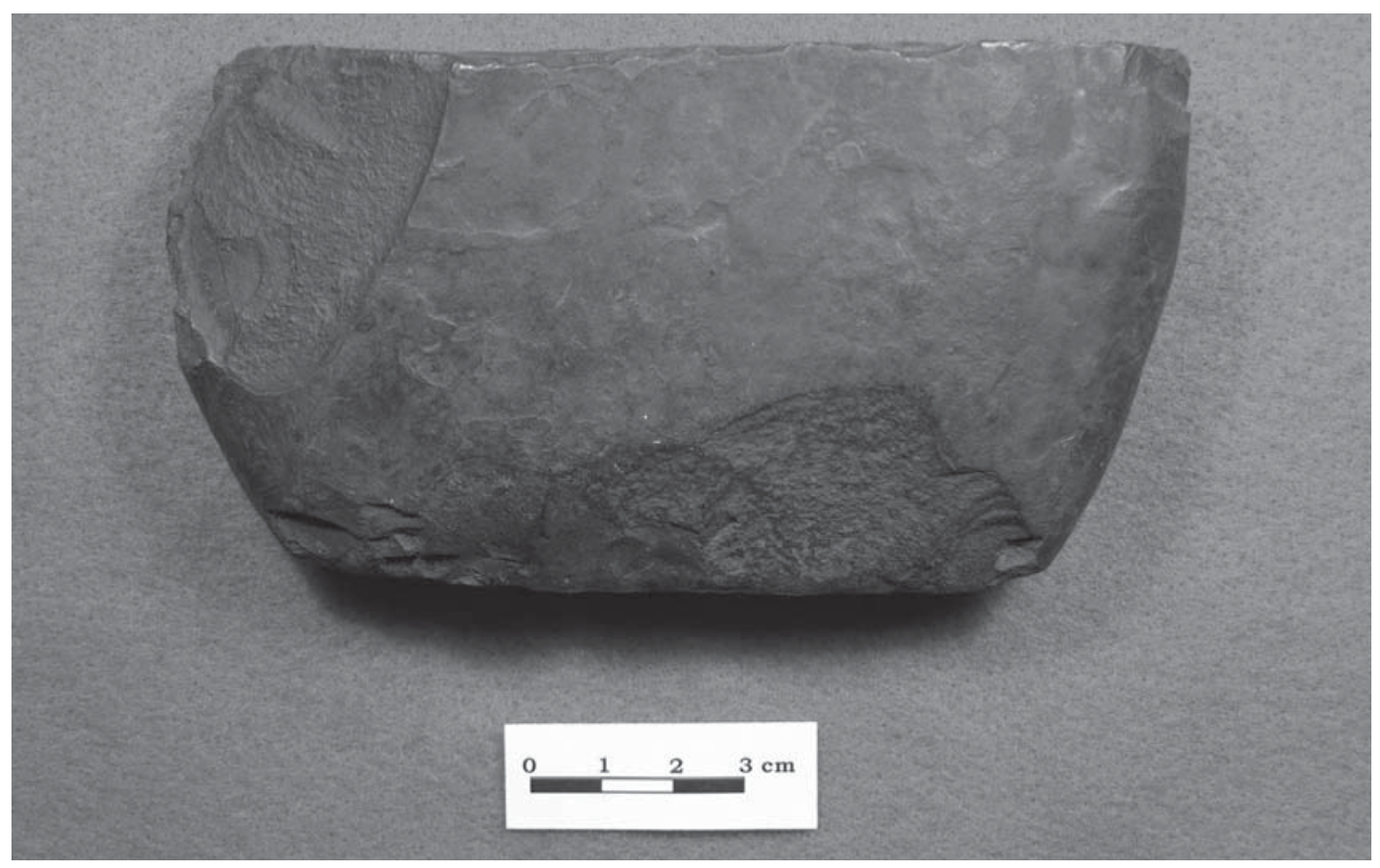

Figure 38. Large hematite celt from the Well Pad area.

tools through core reduction was one of the more common activities which occurred in those areas during the Early Caddoan period occupation of the site.

Eight core types were defined from the Hudnall-Pirtle site, including: tested cobbles, split cobble, single-platform flake, multiple-platform flake, bifacial, bipolar, core fragments, and battered. Core fragments, single-platform flake cores, and split cobble cores are the three most common core types at the site, although core fragments were most common in the Southwest area, tested cobbles were predominant in the Northwest area, and a variety of core types were present in the Well Pad excavations.

Tested Cobbles $(\mathrm{n}=10)$

Provenience: WELL PAD: 113-2, 117-1, 123-2, 124-1; SOUTHWEST AREA: 4-4, 18-4, Shovel Test 2; NORTHWEST AREA: 2-6, 7-13 (2)

The tested cobbles are small cobbles of local raw materials that have had one to a few flakes removed by hard hammer flaking, presumably to determine the worthiness of the raw material for further knapping/reduction. Sixty percent of the tested cobbles are of local chert, followed by quartzite (30\%) and chalcedony (10\%).

Split Cobbles $(\mathrm{n}=13)$

Provenience: WELL PAD: 106-2, 111-1, 0-0-318; SOUTHWEST AREA: 4-5, 8-1, 13-2, 18-6, 21-0, 21-4, 21-5; NORTHWEST AREA: 7-7, 7-13; NEAR BORROW PIT B: Shovel Test 56 
The split cobbles are also generally small pieces (ranging from $25-55 \mathrm{~mm}$ in length) of raw material that were split during initial hard hammer flaking; these cobbles may have been split by breaking them on an anvil or resistant surface, although no bipolar flakes were driven off the pieces before they broke. Local cherts comprise about $46 \%$ of the raw material in this core class, along with coarse-grained quartzite (15\%), Manning Formation chert with a pink cortex $(15 \%)$, hematite $(8 \%)$, petrified wood $(8 \%)$, and a chert from an unknown source $(8 \%)$.

Single-platform Flake Core $(\mathrm{n}=19)$

Provenience: WELL PAD: 111-2, 129-2, 135-1, 137-2; SOUTHWEST AREA: 4-3, 4-4, 6-1, 6-4, 12-3, 13-1, 12-5, 13-5, 16-5, 16-6, 18-6, 18/20-5 (3); PIPELINE MONITORING: 0-0-375

Single-platform flake cores are cores that have had a series of flakes removed in one direction from a usable platform (Figure 39g, i and Figure 40a). On these cores, only a few flakes were removed before either the cores were discarded (because no more usable flakes could be removed) or were broken.

Almost 53\% of the single-platform flake cores are on local cherts, and $26 \%$ are on local fine-grained and coarsegrained quartzite raw materials. Other local raw materials represented in the single-platform flake cores are petrified wood (5\%), chalcedony (5\%) and chert from unknown sources (10.5\%).

Multiple-platform Flake Core (n=9)

Provenience: WELL PAD: 106-2, 123-2, 137-1, Feature 110; SOUTHWEST AREA: 4-4, 13-5, 18-1, 18-2, 21-4

Multiple-platform flake cores from the Well Pad and Southwest Village areas have had flake removals from multiple platforms on pebbles and cobbles of raw material, as flakes were successfully removed from various sides of the piece (see Figure 39a). One of these cores, a small fragment $8.0 \mathrm{~mm}$ thick, was on a piece of novaculite, a non-local raw material that must have been brought to the site after only initial reduction knapping. Other multiple-platform cores are on coarse-grained quartzite (11\%), local chert (33\%), chalcedony (11\%), Manning Formation chert (11\%), and chert from unknown sources (22\%).

Bifacial Core $(n=9)$

Provenience: WELL PAD: 10-8, 135-2; SOUTHWEST AREA: 13-0, 18-1, 21-4 (2), 21-5, 23-2; NORTHWEST AREA: 7-1

Most of the bifacial cores (see Figure 33c and Figure 39b, d, h) are from the Southwest Village area, with additional examples from the Well Pad and Northwest area excavations. These cores have been thoroughly reduced on both sides of pebbles and small cobbles, with bifacial flake removals in various directions on the cores. These cores are an average of $26.4 \mathrm{~mm}$ in length, $22.3 \mathrm{~mm}$ in width, and $12.6 \mathrm{~mm}$ in thickness. Their primary purpose was to serve as a source of usable flakes, and the bifacial cores essentially represent depleted masses of lithic raw material. 


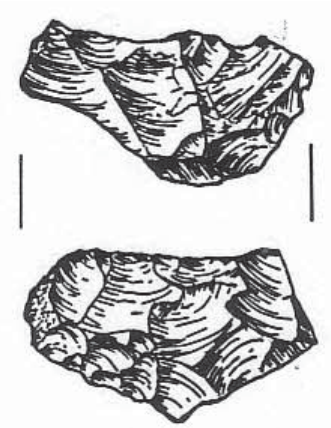

A

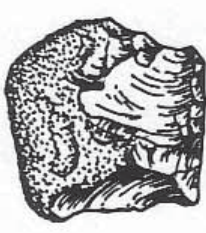

B

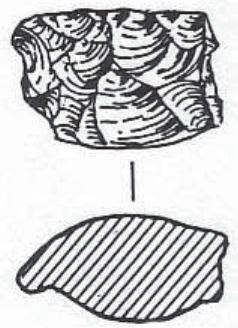

C

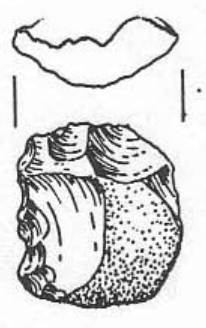

$\mathrm{F}$

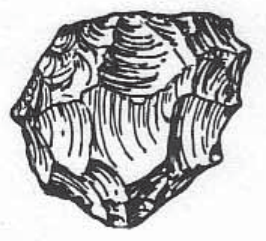

G

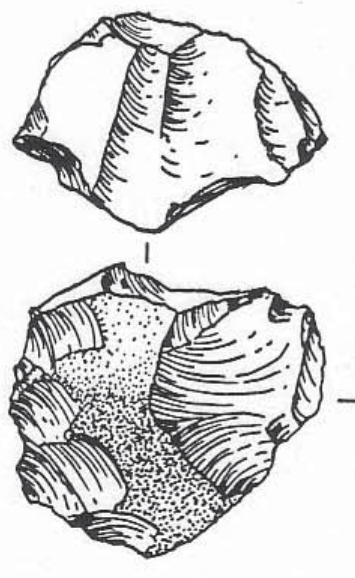

$\mathrm{H}$

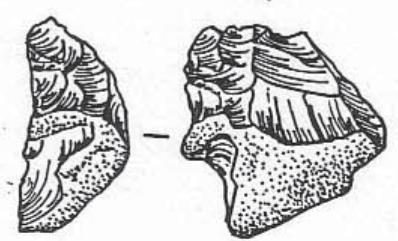

$E$
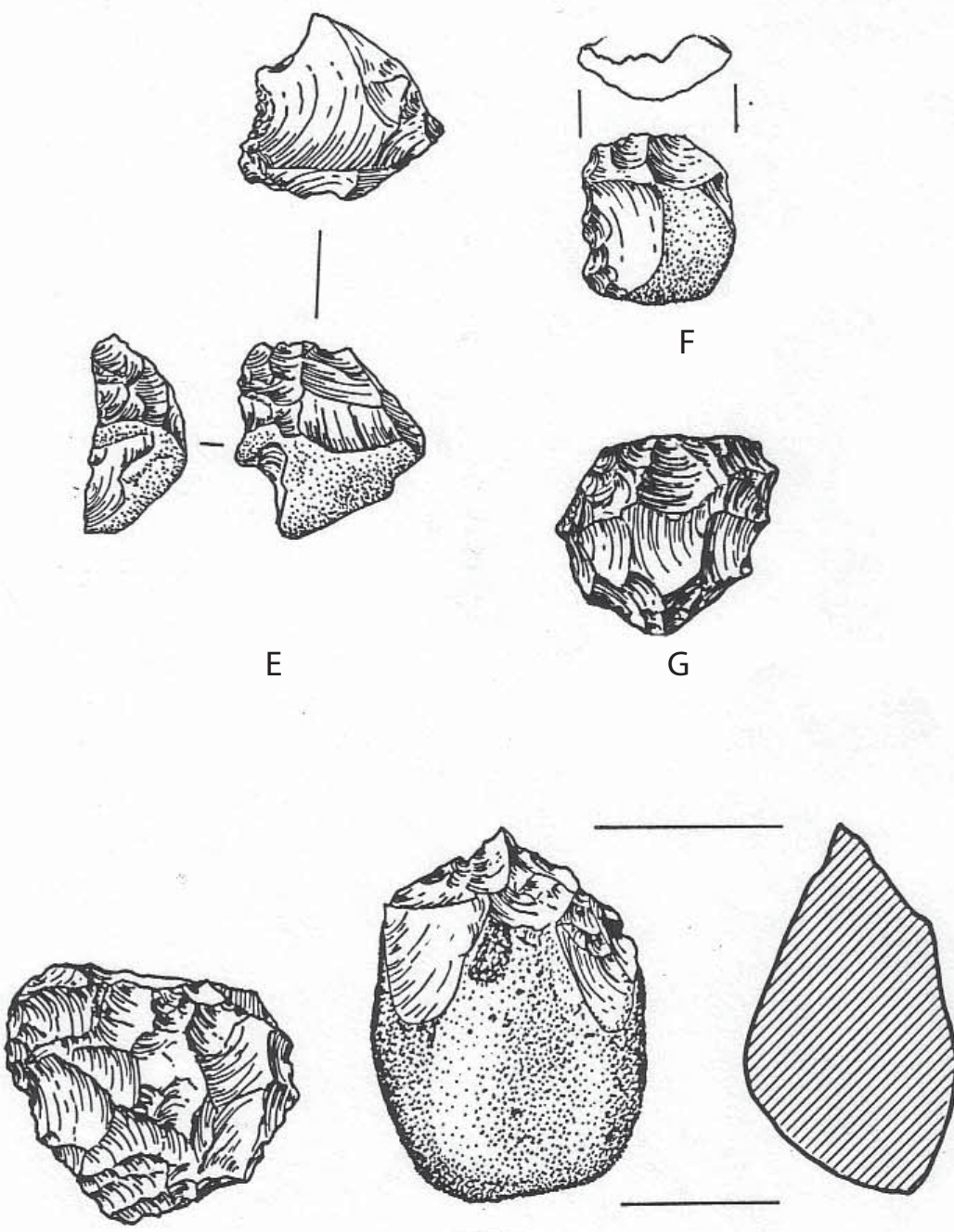

Figure 39. Cores from the Hudnall-Pirtle site: a, multiple-platform flake; b, d, h, bifacial core; c, e-f, bipolar core; g, i, single-platform core. Provenience: a, g, Unit 13, lv. 5; b, Unit 18, lv. 1; c, Unit 18, 1v. 6; d, Unit 13, surface; e, h, Unit 21, lv. 5; f, Unit 16, lv. 5; i, Unit 4, lv. 3. 


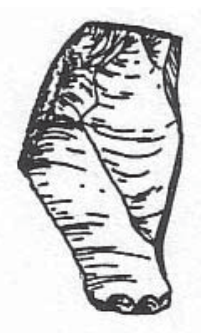

A

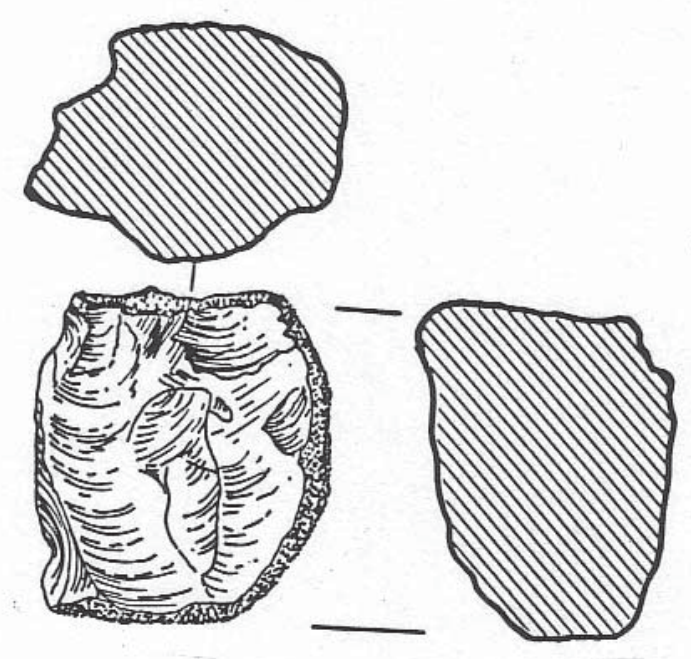

B

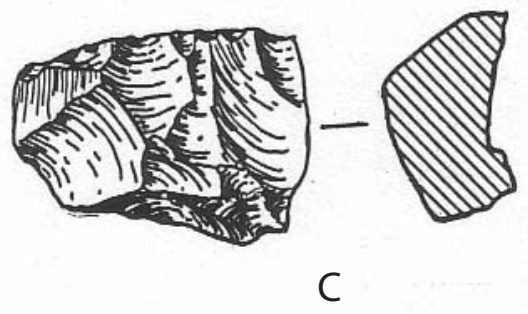

Figure 40. Cores from the Southwest Village and Well Pad excavations: a, single platform flake core; $b$, bipolar core; $c$, core fragment. Provenience: a, Unit 16, lv. 5; b, Unit 6, lv. 5; c, Unit 140, lv. 2).
Bipolar Core $(\mathrm{n}=7)$

Provenience: WELL PAD: 113-2, 134-2; SOUTHWEST AREA: 6-5, 13-5, 16-5, 18-6, 21-5

Bipolar cores are small cobbles of raw material that were broken with a hammerstone on an anvil or resistant raw material, leading to flake removals from opposing surfaces of a core (see Figure 39c, e-f and Figure 40b). The primary purpose of bipolar knapping was apparently to efficiently reduce small cobbles and pebbles of available raw material for the production of flakes for use as tools (see Shafer 1973). Most of the bipolar cores are from the Southwest Village area.

More than $57 \%$ of the bipolar cores are on local cherts, while almost $29 \%$ are on chalcedony. The final bipolar core is on a piece of Manning Formation chert with a pink cortex (see Figure 39e).

Core Fragments $(n=23)$

Provenience: WELL PAD: 107-4, 140-2, Feature 104, Feature 110; SOUTHWEST AREA: 4-1, 4-5 (3), 5-3, 6-3, 6-4, 6-6, 6-8, 12-5, 13-2, 13-4, 203, 20-6, 21-4, 21-5; NORTHWEST AREA: 7-5; NEAR MD. G: Shovel Test 28; PIPELINE MONITORING: 202-4

The core fragments are small pieces from broken cores (see Figure 40c). The small size of the available raw materials for the Hudnall-Pirtle knappers led to the extensive use of pieces of raw material, regardless of the size, leading to frequent breakage during reduction activities. Almost $40 \%$ of the core fragments are either quartzite or local cherts, as well as petrified wood (4\%), baked tuff (4\%), chert with a pink cortex, perhaps a piece of baked tuff (4\%), and unknown cherts $(8.7 \%)$. The occurrence of Manning Formation raw materials among the cores in the Southwest Village suggests that this non-local raw material was brought to the site as either a small cobble or partially reduced core mass. 
Battered Core $(n=1)$

Provenience: SOUTHWEST AREA: Unit 16-Feature 14

The battered core has evidence of flake removals on all surfaces, as well as abraded and crushed platform surfaces, suggesting either core rejuvenation or the use of the Feature 14 core for other crushing and battering activities (perhaps as a hammerstone). The core is on a coarse-grained quartzite, and measures $28 \mathrm{~mm}$ in length, $21 \mathrm{~mm}$ in width, and $16 \mathrm{~mm}$ in thickness.

\section{Lithic Debris}

The majority of the lithic debris from the Hudnall-Pirtle site investigations came from the Well Pad (51.5\%) area, followed by the archeological deposits in the Southwest Village areas (25.9\%); 105 pieces of lithic debris was recovered in features from these two main village deposits, and Unit 10 (near the Well Pad) had 79 pieces of lithic debris (Table 8). Only 8.2\% of the lithic debris came from the Northwest area excavations, with $2.1 \%$ found in the Mound A and Mound F work. Fifty-six pieces of lithic debris were recovered in units excavated along a pipeline right-of-way near Md. C (see Figure 2), and seven pieces came from two excavation units (Units 15 and 17) placed in the large plaza.

In the main village areas (Well Pad and Southwest Village), the lithic debris was recovered between levels 1 through lv. 4-6, and appear to be from a single archeological component. In the Northwest area, however, the lithic debris came from as deep as $140 \mathrm{~cm}$ bs (see Table 8). Here, the lithic debris was concentrated between $10-40 \mathrm{~cm}$ bs and 50-70 $\mathrm{cm}$ bs, possibly suggesting two different periods of occupation on this natural rise. In the Plaza, the few pieces of lithic debris that were recovered came almost exclusively from 50-100 cm bs, probably as part of a limited use of the alluvial terrace at the Hudnall-Pirtle site before the establishment of the Plaza as a formal part of the mound center in Early Caddoan period times. Similarly, most of the lithic debris from Unit 10 came from deeper archeological deposits (i.e., 40-90 cm bs). In Mound A excavations, the lithic debris is sparsely represented throughout the mound fill and the occupational deposits buried by the mound, with no particular concentration of lithic artifacts. By contrast, most of the lithic debris in Mound F came from 70-90 $\mathrm{cm}$ bs (see Table 8), probably associated with the possible upper structural deposits in the mound.

A wide variety of lithic raw materials are represented in the lithic debris from the Hudnall-Pirtle site (Table 9). Not including cherts from unknown sources (but probably from a non-local source), there are 13 different categories of lithic raw materials in the lithic debris assemblage. The most common category is "local chert," consisting of earthen-toned cherts (i.e., brown, red, and yellow cherts). These cherts comprise between 38.7$79.5 \%$ of the lithic debris from the different areas of the site; the local cherts are most abundant in the Well Pad excavations and the southernmost excavation units in the Southwest Village, where it represents more than $65 \%$ of all the lithic debris.

Other important local lithic debris raw materials are quartzite and petrified wood. In the case of the quartzite, it is most abundant in Mound A, the Northwest area, and all three parts of the Southwest Village. In these archeological deposits, quartzite comprises between 17.4-24.2\% of the lithic debris (see Table 9). Petrified wood lithic debris is more common in the Northwest Area, Unit 10 south of the Well Pad, the Plaza, Mound 
Table 8. Lithic debris from the Hudnall-Pirtle Site (41RK4).

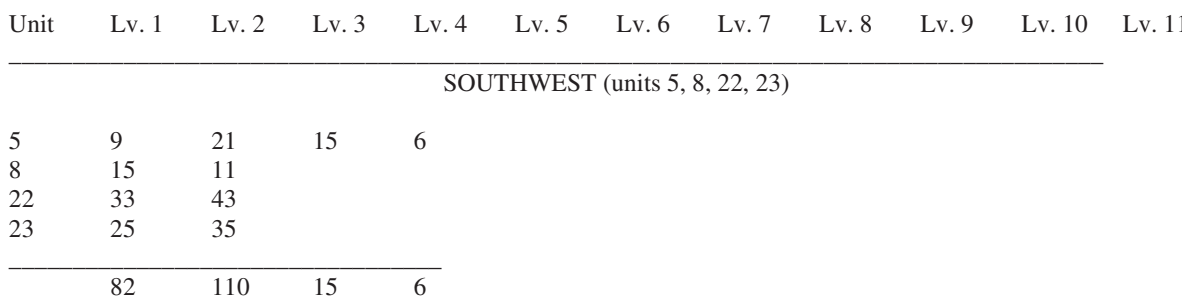

SOUTHWEST (units 4, 18, 20, 21)

\begin{tabular}{lllllll}
4 & 14 & 30 & 10 & 16 & 13 & 6 \\
18 & 3 & 28 & 9 & 22 & - & 5 \\
20 & 1 & 10 & 14 & - & - & 8 \\
21 & 2 & 6 & 12 & 15 & 11 & \\
$18 / 20$ & - & - & - & - & 18 & \\
$4 / 18 /$ & & - & - & - & - & 3 \\
$20 / 21$ & - & - & & & & \\
\hline & 20 & 74 & 45 & 53 & 42 & 22
\end{tabular}

SOUTHWEST (units $6,12,13,16$ )

\begin{tabular}{llllllll}
6 & 12 & 25 & 13 & 4 & 18 & 8 & 1 \\
12 & 4 & 4 & 17 & 8 & 11 & & \\
13 & 10 & 21 & 12 & 13 & 21 & & \\
16 & 4 & 23 & 2 & 10 & - & 6 & \\
\hline & 30 & 73 & 44 & 35 & 50 & 14 & 1
\end{tabular}

NORTHWEST AREA

\begin{tabular}{llllllllllll}
1 & 2 & 2 & 1 & 6 & 1 & 3 & & & & 1 & $1^{*}$ \\
2 & - & 5 & 4 & 1 & 1 & 3 & 2 & 3 & 2 & $3^{* *}$ \\
7 & 7 & 9 & 14 & 7 & 15 & 18 & 24 & 1 & 6 & 4 & \\
19 & 5 & 9 & 16 & 27 & & & & & & & \\
\hline & 14 & 25 & 35 & 41 & 17 & 24 & 26 & 4 & 8 & 5 & 4
\end{tabular}

*6 pieces of lithic debris were also found in lv. 12-14; **17 pieces of lithic debris were recovered in lv. 12-13

WELL PAD NORTH (units 101-123, 133-140)

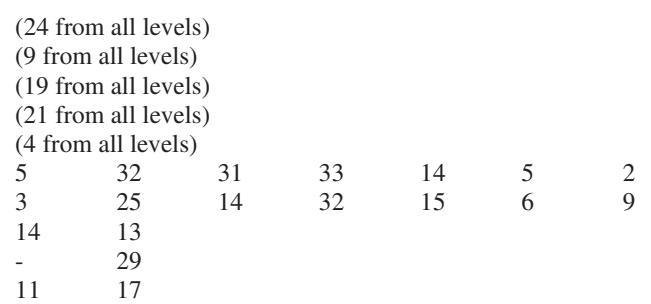


Table 8. Lithic debris from the Hudnall-Pirtle Site (41RK4) Continued.

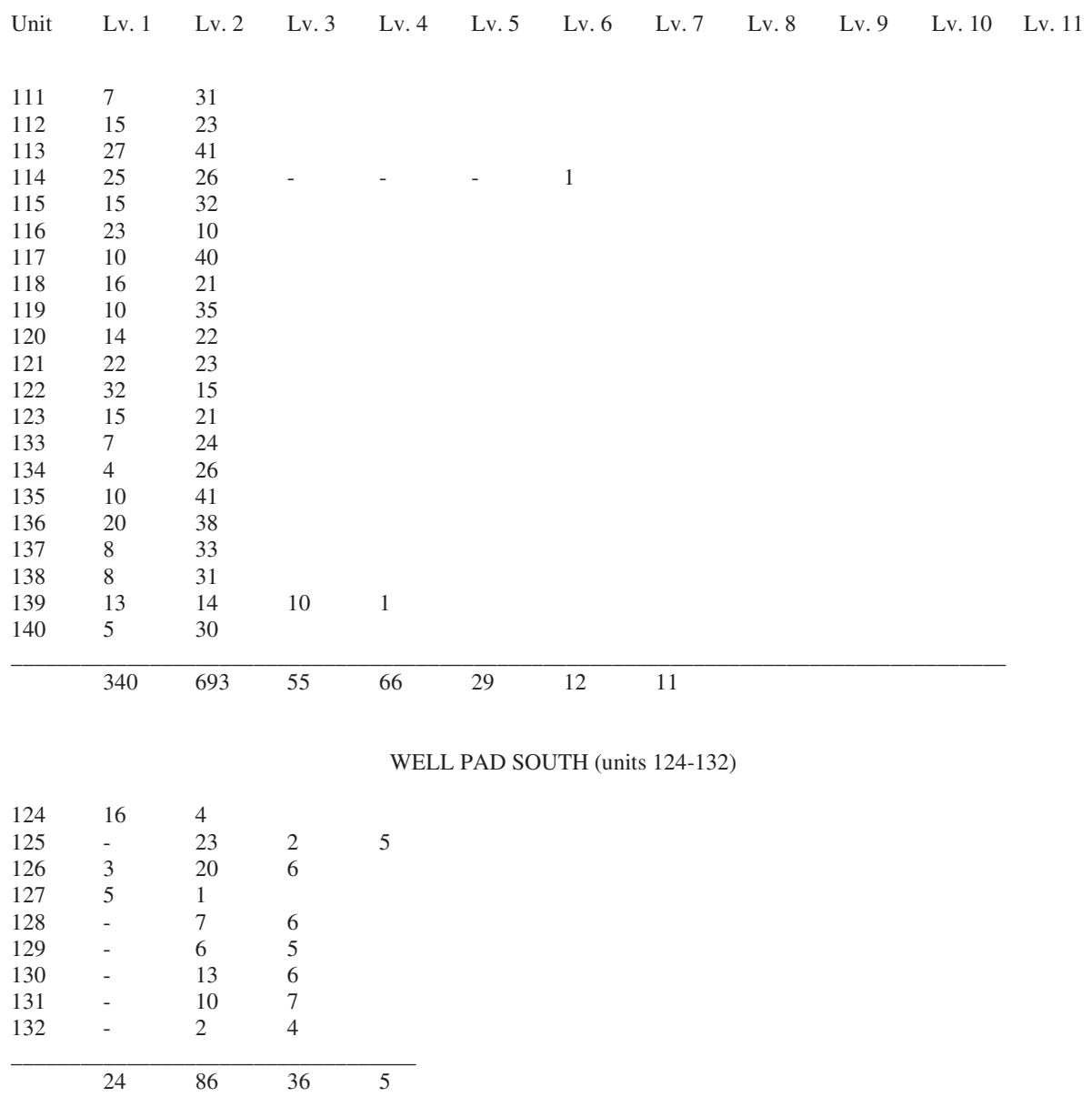

\begin{tabular}{|c|c|c|c|c|c|c|c|c|c|c|c|}
\hline \multicolumn{12}{|c|}{ MOUND A } \\
\hline 14 & 3 & - & 3 & 6 & 1 & 4 & 3 & 3 & 5 & 2 & 2 \\
\hline
\end{tabular}

*lv. 12 also had one piece of lithic debris

\begin{tabular}{llllllllllll}
\multicolumn{10}{c}{ MOUND F } \\
3 & - & - & - & - & - & - & 1 & - & 1 & - & 1 \\
11 & - & 1 & - & - & - & 1 & - & 4 & 11 & 2 & - \\
24 & 2 & - & - & - & - & - & - & - & - & - & $-*$ \\
\hline & 2 & 1 & 0 & 0 & 0 & 1 & 1 & 4 & 12 & 2 & 1
\end{tabular}

UNIT 10 
Table 8. Lithic debris from the Hudnall-Pirtle Site (41RK4), Continued.

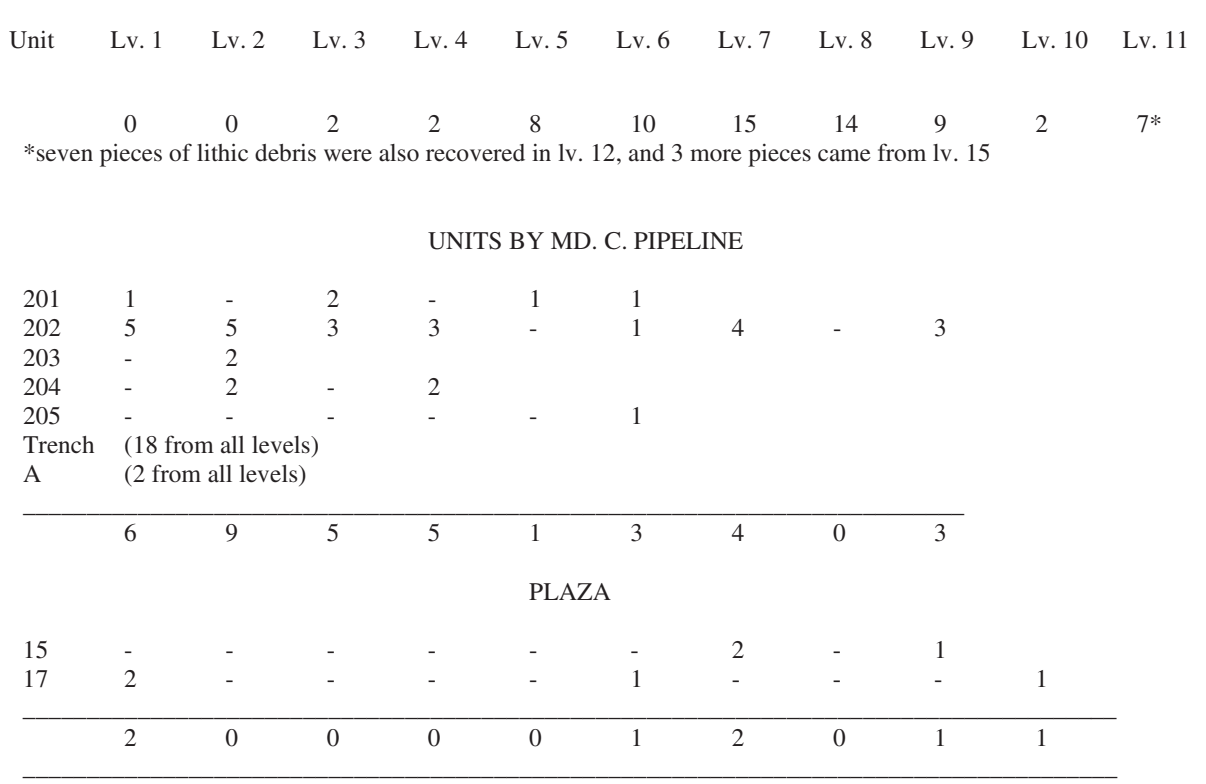

F, units along the pipeline trench by Mound C, and the Well Pad South excavations; petrified wood represents 9.3-17.9\% of the lithic debris samples in those areas. Petrified wood is relatively uncommon in the Southwest Village archeological deposits (see Table 9).

Ferruginous sandstone, hematite, and red ochre pieces comprise only a minor part of the lithic debris assemblage at the Hudnall-Pirtle site. Only in the Northwest, the Mound C pipeline trench, and the northernmost part of the Southwest Village (especially in features in the latter area) do these raw materials represent more than $4 \%$ of the total lithic debris samples. In other areas, these materials account for less than $2 \%$ of the samples (see Table 9).

Chalcedony is apparently present in local gravels (see Bruseth and Perttula 1981: Table 6-7), but not in large quantities. At the Hudnall-Pirtle site, it makes up less than $6 \%$ in any one area at the site, with frequencies ranging from 0.4-3.7\% in habitation areas and 3\% in Mound A deposits; it is generally more frequent in the Well Pad archeological deposits.

There are two different categories of non-local lithic raw materials: (1) the Ouachita Mountains cherts and novaculite found in Red River gravels, and (2) baked and fused cherts from the Manning Formation in East Texas (see Brown 1976: Figure 3). The Ouachita Mountains raw materials are rare. Novaculite was found only in Mound A and the Well Pad excavations (see Table 9), but represents only 0.1-3.0\% of the lithic debris in those areas. The Ouachita Mountains cherts are slightly more common, especially in mound contexts: $3.0-3.8 \%$ of the lithic debris in Mound A and Mound F excavations; they also account for 3.6\% of the lithic debris from units in proximity to Mound C. In habitation areas, the non-local Ouachita Mountains cherts comprise between 1.0-2.3\% of the lithic debris sample, with slightly higher frequencies in the Southwest Village than in either the Well Pad or Northwest areas (see Table 9). 
Table 9. Lithic Debris Raw Materials at the Hudnall-Pirtle Site (41RK4).

\begin{tabular}{|c|c|c|c|c|c|c|c|c|c|}
\hline \multirow[t]{2}{*}{ Area } & \multicolumn{9}{|c|}{ Raw Materials } \\
\hline & 1 & 2 & 3 & 4 & 5 & 6 & 7 & 8 & 9 \\
\hline $\mathrm{SW}(\mathrm{U} 5,8,22,23)$ & 14.6 & 2.8 & 0.5 & - & 1.4 & - & 72.2 & 1.0 & - \\
\hline SW (U4, 18, 20-21) & 16.0 & 3.8 & 1.1 & 0.4 & 2.7 & 2.3 & 59.2 & 2.3 & - \\
\hline SW (U6, 12, 13, 16) & 13.2 & 6.0 & 2.4 & 2.0 & 6.4 & 2.4 & 59.0 & 1.6 & - \\
\hline SW Features & 11.8 & 5.9 & 35.3 & 5.9 & - & 5.9 & 17.6 & - & - \\
\hline Unit 10 & 12.7 & 7.6 & 1.3 & - & 10.0 & - & 64.6 & - & - \\
\hline Well Pad North & 6.2 & 4.3 & 0.6 & 0.6 & 9.3 & - & 69.6 & - & - \\
\hline Well Pad South & 8.3 & 2.7 & 1.9 & 0.3 & 4.5 & Trace & 75.0 & 1.6 & 0.1 \\
\hline Well Pad Features & 4.5 & 1.1 & - & 1.1 & 2.3 & - & 79.5 & 1.1 & - \\
\hline Northwest area & 14.5 & 6.2 & 4.4 & 0.4 & 12.8 & 1.3 & 51.5 & 1.3 & 0.4 \\
\hline Plaza & 14.3 & - & - & - & 14.3 & - & 57.1 & - & - \\
\hline Pipeline by Md. C & 8.9 & 1.8 & 5.4 & - & 17.9 & - & 55.4 & 3.6 & - \\
\hline Md. A & 15.2 & 9.0 & - & - & 3.0 & - & 48.5 & 3.0 & 3.0 \\
\hline Md. F & 15.4 & - & - & - & 15.4 & - & 57.7 & 3.8 & - \\
\hline Shovel tests & 17.2 & 11.8 & 2.2 & - & 16.1 & - & 38.7 & 2.2 & 1.1 \\
\hline
\end{tabular}

*= percentage; Key for Raw Materials: $1=$ fine-grained quartzite; $2=$ coarse-grained quartzite; $3=$ hematite; $4=$ ferruginous sandstone; $5=$ petrified wood; $6=$ Manning Fused Glass; $7=$ local chert, earthen-toned colors; $8=$ non-local cherts, Red River gravels; $9=$ baked tuff; $10=$ chalcedony; $11=$ novaculite; $12=$ red ochre; $13=$ chert with thick pink cortex; $14=$ cherts from unknown sources

The baked and fused cherts, including the very distinctive Manning Fused Glass material, is somewhat more common in habitation contexts at Hudnall-Pirtle than is the Ouachita Mountains cherts and novaculite. The baked and fused cherts have been found primarily in Early Caddoan period contexts in sites in the Sabine River drainage, and a number of sites in the Neches, Trinity, and Angelina river drainages; nowhere is it abundant. At the George C. Davis mound site (41CE19) on the Neches River, for example, Manning Fused Glass accounts for only 2.3\% of the flakes and cores (Brown 1976:196). In the Southwest Village at Hudnall-Pirtle, the baked and fused materials comprise 1.4-6.1\% of the lithic debris, compared to 0.8-2.5\% in the Well Pad excavations; the highest frequency is in Units 4, 18, 20-21 in the Southwest Village (see Table 9). About 2.4\% of the Northwest area lithic debris is baked and fused cherts, as are $3.6 \%$ of the lithic debris sample in the units along the trench near Mound C. There are no baked or fused cherts in the Mound F lithic debris, but 3.0\% in Mound A (see Table 9).

There are distinctive differences across the Hudnall-Pirtle site in the prehistoric Caddo use of lithic raw materials, principally in the use of local cherts and the relative abundance of non-local lithic raw materials. The Well $\mathrm{Pad}$ area and the southernmost units in the Southwest Village have the highest proportions of local cherts (69.6$75.0 \%)$, more petrified wood and chalcedony, and the lowest frequencies of non-local raw materials (1.2-2.6\%) and quartzites. Conversely, habitation areas in the Northwest and other Southwest Village areas have much 
Table 9. Lithic Debris Raw Materials, cont.

\begin{tabular}{|c|c|c|c|c|c|c|}
\hline \multirow[t]{2}{*}{ Area } & \multicolumn{6}{|c|}{ Raw Materials } \\
\hline & 10 & 11 & 12 & 13 & 14 & $\mathrm{~N}$ \\
\hline $\mathrm{SW}(\mathrm{U} 5,8,22,23)$ & 1.4 & - & - & 1.4 & 4.7 & 212 \\
\hline SW (U4, 18, 20-21) & 1.1 & - & - & 3.8 & 7.2 & 262 \\
\hline $\mathrm{SW}(\mathrm{U} 6,12,13,16)$ & 1.6 & - & 0.4 & 1.6 & 3.6 & 251 \\
\hline SW Features & 5.9 & - & - & - & 11.8 & 17 \\
\hline Unit 10 & - & 1.3 & - & 2.5 & - & 79 \\
\hline Well Pad North & 3.7 & - & - & 1.2 & 4.3 & 161 \\
\hline Well Pad South & 2.0 & 0.1 & 0.1 & 0.8 & 2.7 & 1277 \\
\hline Well Pad Features & - & - & - & 1.1 & 11.4 & 88 \\
\hline Northwest area & 0.4 & - & 0.4 & 0.9 & 5.3 & 227 \\
\hline Plaza & - & - & - & - & 14.3 & 7 \\
\hline Pipeline by Md. C & - & - & - & 3.6 & 3.6 & 56 \\
\hline Md. A & 3.0 & 3.0 & - & - & 12.1 & 33 \\
\hline Md. F & - & - & - & - & 7.7 & 26 \\
\hline Shovel tests & 4.3 & - & - & 1.1 & 5.4 & 93 \\
\hline
\end{tabular}

*= percentage; Key for Raw Materials: $1=$ fine-grained quartzite; $2=$ coarse-grained quartzite; $3=$ hematite; $4=$ ferruginous sandstone; $5=$ petrified wood; $6=$ Manning Fused Glass; $7=$ local chert, earthen-toned colors; $8=$ non-local cherts, Red River gravels; $9=$ baked tuff; $10=$ chalcedony; $11=$ novaculite; $12=$ red ochre; $13=$ chert with thick pink cortex; $14=$ cherts from unknown sources

lower frequencies of local cherts (51.5-59.2\%), more hematite and ferruginous sandstone as well as quartzite, and greater amounts of non-local cherts (3.9-8.4\%). Unit 10 is more like the Well Pad area in lithic debris raw materials, while Mound A, Mound F, and pipeline trench deposits near Mound C more closely resemble the Northwest and other Southwest Village areas.

These basic differences in raw material use at the Hudnall-Pirtle site continue in other aspects of the lithic debris. For instance, only 15.8-20\% of the lithic debris in the Well Pad area and the southernmost part of the Southwest Village are heat-treated, compared to 22.9-30.9\% of the lithic debris in the Northwest area and the other Southwest Village areas. This is closely related to areal (and temporal?) differences in the use of quartzite, as this material was commonly heated to improve its knappability. Biface thinning flakes are more abundant in the Well Pad/ southernmost Southwest Village areas (3.8-4.2\%), compared to 0.2-1.3\% in the Northwest and other Southwest Village areas. This difference obviously is related to diverse knapping strategies between these two main habitation areas, suggesting that final stage knapping of larger bifacial tools did not occur with regularity across the site, but was concentrated in the Well Pad archeological deposits.

Bipolar flaking was also more common in the Well Pad and southernmost Southwest Village areas, with 1.2$3.8 \%$ of the lithic debris sample representing flakes from bipolar cores; they were most abundant in the Well 
Pad South excavations. Their relative frequency is probably a product of the heightened emphasis on local cherts in these areas, since the local chert raw materials are rather small in size, and bipolar reduction would have been a very suitable knapping technique to produce usable flakes for tools. In the Northwest and other Southwest Village areas, between $0.3-2.6 \%$ of the lithic debris is bipolar; the lowest proportions ( $0.3 \%)$ occur in the other Southwest Village areas.

\section{Fire-Cracked Rock}

There were 45 pieces of fire-cracked rock recovered in the excavation of habitation areas at the Hudnall-Pirtle site. Most of these were from the Southwest Village $(n=21)$ and the Well Pad $(n=21)$, along with one piece in a shovel test south of Md. $\mathrm{H}$ and west of Borrow Pit $\mathrm{C}$, and two pieces in the pipeline trench near Mound $\mathrm{C}$. These fire-cracked rocks were found between $0-70 \mathrm{~cm}$ bs. The overall scarcity of fire-cracked rock at the site suggests that the Early Caddoan period occupants did not rely on indirect methods of cooking using heated rocks, but instead principally cooked and boiled foods in ceramic vessels placed directly over fires.

\section{Summary of the Lithic Artifacts and Regional Comparisons}

In this section are first summarized the findings of the Hudnall-Pirtle lithic artifact analysis with respect to the research problems posed in the introduction to this section, specifically (1) the characterization of the nature of the Early Caddo lithic tool assemblage at the site, (2) tool diversity and its relationship to the site's function, and (3) the acquisition and use of non-local lithic raw materials. Following the discussion of these issues, we turn to assemblage-wide comparisons with selected other Early Caddoan period sites in the northeastern Texas and northwestern Louisiana region. The purpose of these comparisons is to place the Hudnall-Pirtle lithic artifact assemblage, from various parameters, within its broader cultural context and attempt to discuss how the lithic artifacts are informative about Early Caddo lifeways.

The Early Caddo lithic assemblage from the Hudnall-Pirtle site is dominated by expedient unifacial tools and bifacially chipped arrow points of various stemmed forms, and numerous small cores. By expedient, I follow Tomka's (2001:209) definition, namely that "expedient tools represent flake/blade blanks that have not been altered prior to their use in the performance of a task (e.g., the use of an unmodified flake as a knife or scraper)." Other than the arrow points, there are only a few formal tools (i.e., hafted tools) in the chipped or ground stone tool assemblage, including fragments of large bifacial tools (such as Gahagan bifaces), bifacially chipped drills, and two ground stone celts.

There are significant differences from one part of the site to another in the kinds of chipped and ground stone tools found in Early Caddo domestic contexts (Table 10), as well as in the frequency of discarded cores. For the site as a whole, unifacial tools comprise $41 \%$ of the tools and cores, and they are most abundant in the Well Pad area and Mound A, followed by the Southwest Village area. Projectile points - in this case a number of varieties of stemmed arrow points, dominated by Alba points - are very common in the Northwest area, followed by the Well Pad excavations (see Table 10).

The differing frequencies of arrow points between the various areas at the Hudnall-Pirtle site probably reflect 
the intensity at which hunting large game animals were emphasized from area to area, or at least the locations of steady processing of large game animals. The overall low frequency of formal tools in the Hudnall-Pirtle tool assemblage may be indicative of a general decreased reliance by the Caddo inhabitants in the procurement of hunted resources, and those that were procured could be readily processed with expedient tools (cf. Tomka 2001:222). The decreased reliance on game animals may be a product of the increased production in an agricultural economy of cultivated plant foods, such as maize, by the Caddo (see Fritz, next section), and large surpluses of meat were not consistently needed (see Abbott et al. 1998). In that case, "hunting patterns may have shifted away from the procurement of large quantities of surplus to smaller quantities of meat on a steady basis" (Tomka 2001:222-223).

Bifacial tools (including preforms and indeterminate fragments) only account for $10 \%$ of the tools and cores from the site (see Table 10), and many of those (see above) are fragments of arrow point preforms and bifacial tools that appear to have been broken during use. They are only common in the Northwest area and in archeological deposits in the vicinity of Mound C (the pipeline trench), and much less abundant proportionally in the Southwest and Well Pad village areas. However, the bifacial tools that actually have evidence of use (including bifacial tool fragments and large hafted bifaces) are found only in three areas at the Hudnall-Pirtle site: the Well Pad (3.2\%), the Southwest Village (2.7\%), and along the pipeline trench (16.7\%). It is in these areas where more intensive but occasional processing of game animals probably took place during the Early Caddoan period occupation.

Ground stone tools are generally rare across the site, comprising only 3.3\% of the 399 lithic tools and cores in the site assemblage (see Table 10). In the three main habitation areas investigated by the Texas Historical

Table 10. Tools and Cores from different parts of the Hudnall-Pirtle site.

\begin{tabular}{|c|c|c|c|c|c|c|}
\hline Areas & $\begin{array}{l}\text { Ground } \\
\text { Stone tools }\end{array}$ & $\begin{array}{l}\text { Unifacial } \\
\text { tools }\end{array}$ & $\begin{array}{l}\text { Projectile } \\
\text { points }\end{array}$ & $\begin{array}{l}\text { Bifacial } \\
\text { tools }\end{array}$ & Cores & $\mathrm{N}$ \\
\hline Southwest & $2.7^{*}$ & 39.0 & 18.7 & 8.8 & 30.8 & 182 \\
\hline Well Pad & 2.6 & 50.0 & 24.7 & 8.4 & 14.3 & 154 \\
\hline Northwest & 3.8 & 15.4 & 38.5 & 15.4 & 26.9 & 26 \\
\hline Pipeline & 8.3 & 16.7 & 25.0 & 33.3 & 16.7 & 12 \\
\hline Mound A & 16.7 & 50.0 & 16.7 & 16.7 & -- & 6 \\
\hline Unit 10 & -- & 33.3 & 33.3 & 16.7 & 16.7 & 6 \\
\hline Shovel tests & 8.3 & 33.3 & 33.3 & -- & 25.0 & 12 \\
\hline Mound F & -- & 100.0 & -- & -- & -- & 1 \\
\hline Totals & 3.3 & 41.0 & 22.2 & 9.8 & 22.8 & 399 \\
\hline
\end{tabular}


Commission, ground stone tools account for 2.6-3.8\% of the tools and cores, strongly implying that plant food grinding activities were conducted to the same extent. These were used for the grinding and processing of plant foods, including seeds and maize kernels, as well as wood working.

Cores are particularly abundant in the Northwest and Southwest Village areas at the Hudnall-Pirtle site, accounting for 26.9-30.8\% of all the tools and cores in those two Early Caddoan period habitation areas. It is suspected that relatively intensive tool manufacturing activities using multi-directional core reduction knapping strategies took place in these parts of the site. Core reduction is an efficient knapping strategy in the manufacture of flake tools and smaller flake blanks (for arrow points) from locally available raw materials that occur primarily as pebbles and small cobbles in local gravels. The few larger bifacial tools must have been made using bifacial reduction strategies, relying on larger pieces of lithic raw material as well as the acquisition of bifacial tools from non-local sources (i.e., the Gahagan biface made from Edwards Plateau chert).

Although there are differences in the proportion of unifacial tools from the Well Pad and Southwest Village areas (see Table 10), the composition of the tools are very much the same from both areas. That is, the most frequent unifacial tool in both areas is the expedient edge-modified piece (62-71\%), followed by retouched pieces (9.1-12.7\%). More specialized tools such as gravers and drills/perforators are equally abundant in the two areas (7.0-7.8\% and 3.9-4.2\%, respectively), as are flake scraping tools (6.5-9.8\%).

The overall similarity in the range of chipped and ground stone tools across the different habitation areas at the Hudnall-Pirtle site suggest that a wide variety of domestic tasks took place in each part of the site, including hunting, game animal processing, the processing of gathered and cultivated plant foods, and tool production. It seems likely that many parts of the Hudnall-Pirtle site had a number of domestic compounds of extended families, each of which generally engaged in the same range of domestic tasks. Some of these tasks were done to support the activities of the social and political elite that also lived at the site, but most of which were really part of the same domestic economy that could be found among Caddo families living elsewhere in the larger Early Caddoan period community.

The lithic tools and debris from the Hudnall-Pirtle site are dominated by the use of pebbles and small cobbles of local raw materials, especially local earth-toned cherts, fine-grained and coarse-grained quartzite, and petrified wood. Nevertheless, non-local lithic raw materials are relatively abundant in all investigated contexts at the site, especially in the arrow points, unifacial tools, and the large hafted bifaces. The latter are from Edwards Plateau cherts in Central Texas (see Frederick et al. 1994), and the two from Hudnall-Pirtle are both from these chert sources. About $13 \%$ of the arrow points are made from non-local lithic materials, including Ouachita Mountain cherts and novaculite, while $20 \%$ of the unifacial tools are made from the same non-local materials, and some are also made from Manning Formation sources in the southern part of northeastern Texas (see K. Brown 1976: Figure 3); these materials include Manning Fused Glass, baked tuff, and cherts with a thick pink cortex.

All these non-local lithic raw materials must have been obtained by the Caddo at the Hudnall-Pirtle as substantially reduced cores, flake blanks, or nearly-completed form because the proportion of non-local lithics in the lithic debris is a good bit less than it is for the finished tools. Novaculite lithic debris was found only in the Well Pad excavations, while non-local cherts and Manning Formation materials came from all habitation areas; the Manning Formation materials were most common in these contexts, and there were also some small flake cores of these materials in the lithic assemblages. This suggests stronger trade and exchange relationships with the aboriginal peoples that lived in the southern part of northeastern Texas than with Caddo groups living north of the Hudnall-Pirtle site (probably on the Red River in northeastern Texas) who would have had ready access to Ouachita Mountains cherts and novaculite. 
How do the lithic assemblages from other Early Caddoan sites, including mound centers and sedentary domestic sites not associated with mound-building activities? Selected examples are discussed in the following paragraphs, beginning with the James Pace site in northwestern Louisiana.

The James Pace mound site (16DS268) on the Sabine River in De Soto Parish was apparently occupied between ca. A.D. 650-1000 (see Girard 1994; McGimsey and van der Koogh 2001), abandoned just about the time the Hudnall-Pirtle site was first occupied by Caddo peoples. Most of the chipped stone tools found there in the excavations reported by Jensen (1968) include unifacial tools $(n=213)$ and arrow points $(n=143)$, in similar proportions to the Hudnall-Pirtle tool assemblage, with a small number of more specialized flake tools, including gravers $(n=18)$, drills $(n=1)$, denticulates $(n=1)$, as well as several bifacial $(n=6)$ and unifacial flake knives $(\mathrm{n}=11)$, and 31 knive fragments. Thus, there may have been periodic intensive game processing at the James Pace site during its lengthy occupation. Cores were especially abundant, with 720 fragments, including single platform, opposed, and bipolar cores. Jensen (1968) identified only very low amounts of non-local lithic raw materials at the site, greatly contrasting to the situation at the Hudnall-Pirtle site, as only about $3 \%$ of the arrow points, $5 \%$ of the unifacial tools, and $0.6 \%$ of the lithic debris were from non-local sources, including non-local cherts, novaculite, and Catahoula sandstone.

The George C. Davis mound center (41CE19) and village has a large Early Caddoan period lithic assemblage (see Shafer 1973; Story 1981:239-345). The arrow points (more than 1140 in number) are predominately stemmed Alba points, and only about $1.5 \%$ were apparently made from non-local lithic materials, including novaculite and Manning Fused Glass (this percentage may be higher, however, because no non-local cherts were identified or quantified in the Shafer [1973] and Story [1981] analyses). Only about 1\% of the lithic debris and unifacial tools in Story's (1981) investigations have been reported from village contexts at the George C. Davis to be of non-local materials (i.e., Manning Fused Glass), although Shafer (1973:259) noted that most of the smaller sample $(n=31)$ of expedient unifacial tools from the 1940s and 1960s excavations were made from non-local materials "and may not represent artifacts made at the site." In general, however, it does appear to be the case that the Caddo group living at the Hudnall-Pirtle mound center had a wider access to non-local lithic raw materials than did the Caddo community at the contemporaneous George C. Davis site.

In Story's (1981) lithic tool assemblage from George C. Davis, arrow points are slightly more abundant than unifacial tools (282:234, or a ratio of 1.2:1), but specialized perforating tools are common $(n=40)$ among the flake tools, as they are at Hudnall-Pirtle; Shafer (1973) had another 31 perforators (or awls) in the earlier assemblage studied from the site. The George C. Davis site lithic tools are notable for the common occurrence of large hafted bifaces made from non-local Edwards Plateau chert, and they are found in both mortuary and domestic contexts; these are large formal tools that may have been employed in the intensive processing of game animals, and their inclusion in mortuary assemblages (along with large caches of arrow points) testify to their importance in some Early Caddoan lithic tool kits.

The ground stone tool assemblage at George C. Davis includes many polished celts ( $\mathrm{n}=55$ in the Shafer [1973] and Story [1981] samples) made from non-local raw materials. There is also a wide variety of other kinds of ground stone tools $(\mathrm{n}=91)$ that were used in plant processing and tool sharpening, including abraders, grinding slabs, sandstone saws, milling stones or metates, hones, anvils, battered stones, and polishing stones. Ground stone tools are much more common in the George C. Davis tool assemblage, accounting, for almost $10 \%$ of the tools tabulated in Story (1981), compared to only 3.3\% at the Hudnall-Pirtle site. Similarly, the ratio of arrow points to ground stone tools at George C. Davis is 3.2:1, while the ratio at Hudnall-Pirtle is 7.1:1. Hunting of large game animals was apparently a more important subsistence pursuit at the Hudnall-Pirtle site in Early Caddoan period times than it was at the George C. Davis mound center. 
At the Boxed Springs mound center (41UR30), occupied during the Early Caddoan period (perhaps the earlier part of the period since there are numerous Spiro Engraved vessels in the ceramic assemblage), the many stemmed arrow points were made from fine-grained and coarse-grained quartzite, local cherts of brown and yellow hue, and high quality cherts that probably originated in the Ouachita Mountains and/or Red River gravels (Perttula et al. 2000:48). Several Gahagan bifaces were recovered in a shaft tomb in Mound A, and these were made from Edwards chert. Small celts of different shapes were relatively abundant, here as well at least in mortuary contexts, and these were made from metamorphic or igneous rocks available in the Ouachita Mountains, and probably brought to the site in completed form. There was a single ferruginous sandstone sawing tool (see Perttula et al. 2000:Figure 10) at the Boxed Springs site that closely resembles the tabular sandstone saws recovered in Early Caddoan period contexts at the George C. Davis site (Shafer 1973:317 and Figure 25h-i). Other ground stone tools from the site include two polishing stones and one mano.

At the Taddlock site (41WD482) on Lake Fork Creek, a domestic Early Caddoan settlement dated between cal AD 974-1160 (Perttula 1998:Table 1), stemmed arrow points outnumbered expedient flake tools almost 2: 1 (82 vs. 47) (Bruseth and Perttula 1981:101-116), whereas flake tools were much more common in the HudnallPirtle assemblage. These differences may highlight different functional emphases of the domestic compounds in a mound center to independent dispersed and self-sustaining domestic settlements found some distance from Early Caddoan period mound centers. There were a number of drills and perforators at Taddlock, as there were at Hudnall-Pirtle (and other Early Caddoan period sites such as George C. Davis), but almost no gravers or other more specialized flake tools. Large hafted bifaces were also absent. Manos and pitted stones were infrequent $(n=9)$, but celts were relatively numerous $(n=5)$ at Taddlock. It is interesting that the Early Caddoan period inhabitants at the Taddlock site apparently had better access to non-local lithic raw materials than did the people in domestic areas at Hudnall-Pirtle, since almost $40 \%$ of the tools (especially celts, perforators/drills, scrapers, and flake tools) were made from non-local raw materials (much of it from the Ouachita Mountains) (Bruseth and Perttula 1981; Perttula 1984). Similarly, the local materials preferred at the Taddlock site were quartzite and petrified wood, not local cherts.

The Early Caddoan period domestic component at the Smithport Landing site in De Soto Parish has a lithic assemblage also dominated by arrow points $(n=67)$, with only a few flake tools, including flake scrapers $(n=16)$, knives $(n=2)$, and drills $(n=4)$ (Webb 1963). The ratio of arrow points to flake tools here is 3:1, while at HudnallPirtle it is 1:1.8. Only about $6 \%$ of the arrow points are made from non-local cherts and novaculite, compared to $13 \%$ at Hudnall-Pirtle; the lithic debris is not discussed by Webb (1963). The rare ground stone implements found at the site are one polished celt, one pitted stone, and a single whetstone.

\section{Copper Bead}

A small copper bead was found in level $4(30-40 \mathrm{~cm})$ of Unit 4 in the Southwestern part of the site (see Figure 2 ). The bead is formed of cold hammered copper and appears to have been spherical in shape. There is some uncertainty about the overall shape of the bead because about one-third of one side including one of the two holes is missing, and some deformation of the bead shape occurred as a result. The bead is $13 \mathrm{~mm}$ in diameter, and the remaining hole has a diameter of $5 \mathrm{~mm}$. 


\title{
ARCHEOBOTANICAL REMAINS FROM THE HUDNALL-PIRTLE SITE (41RK4),
}

\section{RUSK COUNTY, TEXAS,}

\author{
by Gayle J. Fritz
}

Eighteen flotation samples from the Hudnall-Pirtle site were analyzed at the Paleoethnobotany Laboratory at Washington University in St. Louis. The samples came from 17 features, with two samples from Feature 14 having such different contents that they are treated separately. Soil volume prior to flotation varied from 0.38 liters to 7.57 liters, for a total of 56.6 liters. The flotation system used was a modified SMAP-type machine. Light fraction mesh size was $0.5 \mathrm{~mm}$, whereas $1.0 \mathrm{~mm}$ mesh was used for recovery of heavy fractions. Results are summarized in Table 11, and presented in detail in Table 12. Sorting was carried out by Steve Rhee, Kimberly Schaefer, and Gayle Fritz, and Fritz checked all the identifications.

Recovery of archeobotanical remains was difficult due to the heavy clay matrix and the presence of many small stones. Charred materials are virtually absent from light fractions, even from those samples where heavy fractions are rich in wood charcoal, nutshell, and/or maize. Fifty toasted, but not charred, poppy seeds were added to the soil sample from Feature 109 prior to flotation to test for effectiveness of recovery. Only 14 poppy seeds were retrieved. Furthermore, archeobotanical remains were typically coated by and saturated with hardened clay, slowing analysis and making it necessary to deviate from standard laboratory procedures, as described below.

\section{Laboratory Methods}

Each light fraction and each heavy fraction was weighed on an Ohaus electrical balance and passed through a set of brass geological sieves with openings varying from $4.0 \mathrm{~mm}$ to $0.425 \mathrm{~mm}$. Particles larger than $2.0 \mathrm{~mm}$ were sorted into constituent categories as presented in Table 11. Wood charcoal, bark, stone, and uncarbonized plant remains were weighed to the nearest $0.01 \mathrm{~g}$, but not counted. Fragments of pitch, hickory nutshell, acorn shell, acorn nutmeat, maize, seeds, and unknown items were counted and also weighed to the nearest $0.01 \mathrm{~g}$.

Acorn shell, maize, and seeds normally would have been pulled from all $1.4 \mathrm{~mm}$ and possibly also $1.0 \mathrm{~mm}$ sieve fractions. This was not done for six of the largest heavy fractions from Hudnall-Pirtle due to the excessive amount of time necessary to distinguish clay-encrusted plant fragments from the thousands of tiny pebbles and clay particles in the same fractions. Heavy fractions from both of the Feature 14 samples were unsorted below $2.0 \mathrm{~mm}$, and the same was true of heavy fractions from Features 17, 104, 106, and 111. Counts, weights, and densities of maize and acorn nutshell are considerably lower than if smaller-sized pieces had been pulled, and the Hudnall-Pirtle values, therefore, are not directly comparable to those of assemblages from sites where tables include counts and/or weights of these items down to $1.4 \mathrm{~mm}$ or smaller. However, it is unlikely that the Hudnall-Pirtle seed count would increase significantly with more complete sorting of small sieve sizes. Seeds were pulled from the 1.4 and $1.0 \mathrm{~mm}$-sized groups from most $(\mathrm{n}=12)$ of the heavy fractions and from all 18 of the light fractions, and smaller-than- $2.0 \mathrm{~mm}$ particles from unsorted heavy fractions were scanned briefly, with negative results, to see if small seeds were present. Seeds are remarkably rare in this assemblage. The heavy clays and resulting poor recovery of light fraction material may be a factor contributing to the low seed counts, but full sorting of smaller-than- $2.0 \mathrm{~mm}$ particles in all heavy fractions would probably not change the current situation. 
Table 11. Summary of Archeobotanical Remains from the Hudnall-Pirtle site (41RK4).

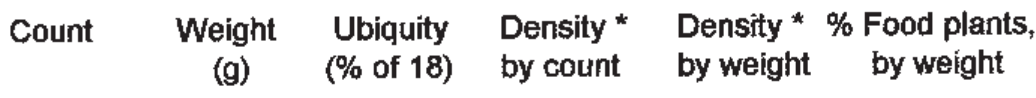

\begin{tabular}{|c|c|c|c|c|c|c|}
\hline Wood and Bark & - & 23.55 & 100 & - & 0.416 & - \\
\hline Pine Pitch & 6 & 0.10 & 5.6 & - & 0.002 & - \\
\hline Cane Stem & 25 & 0.46 & 16.7 & 0.442 & 0.008 & - \\
\hline Hickory nutshell & 113 & 2.16 & 61.1 & 1.996 & 0.038 & 6.8 \\
\hline Acom shefl & 158 & 0.85 & 55.6 & 3.268 & 0.044 & 7.9 \\
\hline Acorn nutmeat & 27 & 1.66 & & & & \\
\hline Total Nut & 298 & 4.67 & 72.2 & 5.264 & 0.082 & \\
\hline Total Majze & 3074 & 26.98 & 44.4 & 54.301 & 0.477 & 84.8 \\
\hline Kemel fragment & 18 & & & & & \\
\hline Cupule & 2810 & & & & & \\
\hline Glume & 246 & & & & & \\
\hline Seeds & 5 & 0.15 & 16.7 & 0.088 & 0.003 & 0.5 \\
\hline Persimmon & 2 & & & & & \\
\hline $\begin{array}{l}\text { Purslante } \\
\text { Unid Frag }\end{array}$ & 1 & & & & & \\
\hline Viliu. Flag. & 2 & & & & & \\
\hline Unknown & 1085 & 7.90 & 88.9 & 19.166 & 0.140 & $=$ \\
\hline
\end{tabular}

*Density is the amount divided by the number of liters of soil floated (56.61)

\section{Contents of the Samples}

Wood charcoal is the most ubiquitous type of archeobotanical material at Hudnall-Pirtle, being present in all 18 samples (100\% ubiquity), with a total weight of $23.55 \mathrm{~g}$ when combined with bark. Cane stem (Arundinaria gigantea) occurs in three samples (ubiquity is 16.7\%) but is most abundant in Feature 12 in Mound F, probably reflecting combustion of building material or utilitarian objects such as mats or baskets. Food plants are represented by thick hickory nutshell (Carya spp.), acorn nutshell and acorn nutmeat (Quercus spp.), maize kernel and cob fragments (Zea mays ssp. Mays), persimmon seed (Diospyros virginiana), and purslane seed (Portulaca oleracea).

A total of 113 fragments of hickory nutshell weigh $2.16 \mathrm{~g}$. The Hudnall-Pirtle archeobotanical assemblage includes 158 pieces of acorn shell weighing $0.85 \mathrm{~g}$ and 27 recognizable fragments of acorn nutmeat weighing 


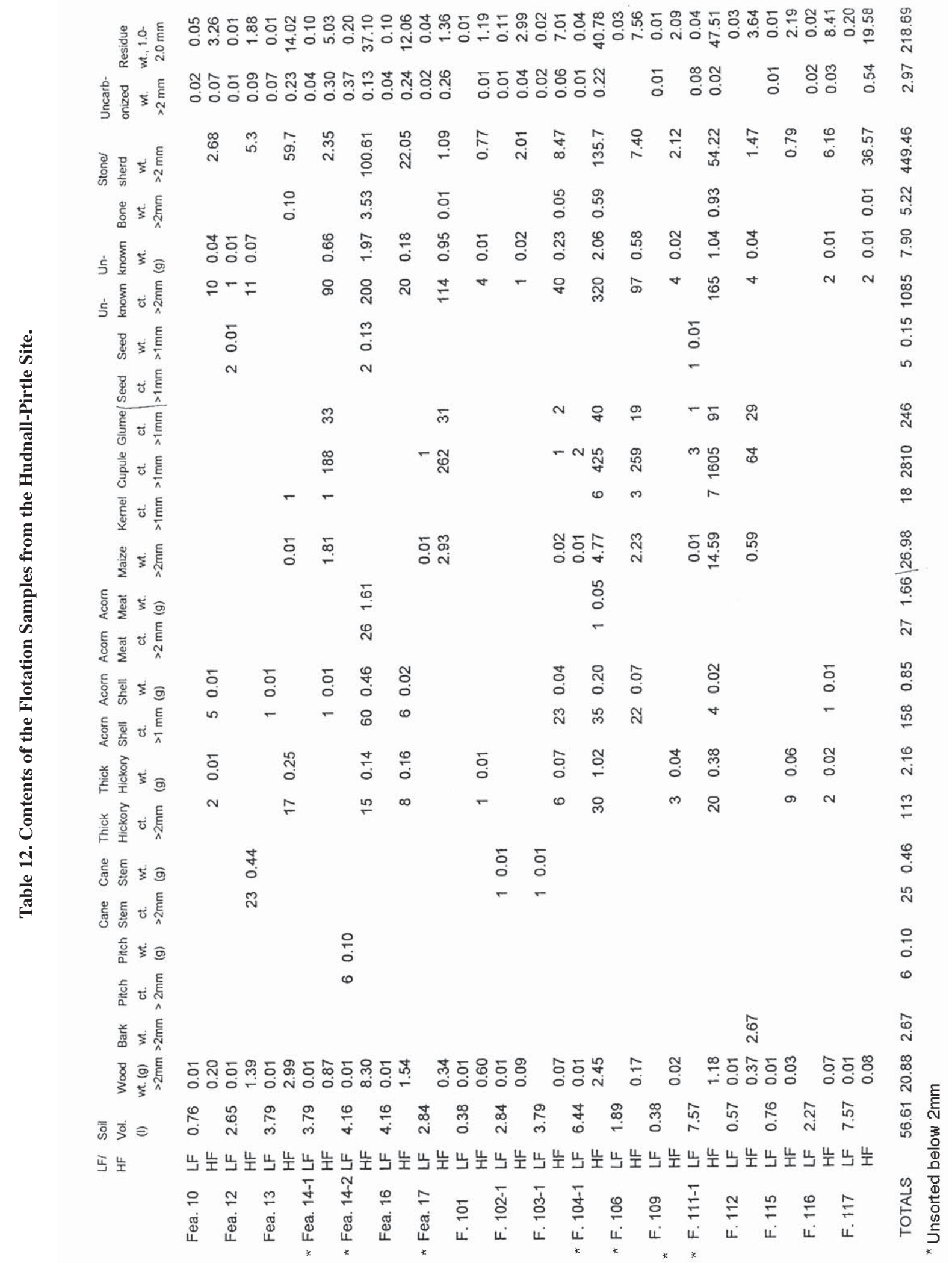


$1.66 \mathrm{~g}$. Maize is represented by 3074 fragments. The total weight of maize, $26.98 \mathrm{~g}$, exceeds the weight of wood charcoal in spite of the fact that very little maize smaller than $2.0 \mathrm{~mm}$ is included. The counts and weights of nut remains (hickory and acorn), even when combined, are far lower than those of maize. The weight of maize exceeds that of nuts by a factor greater than 5.0. However, hickory nutshell is present in $61.1 \%$ of the samples, and acorn in $55.6 \%$, compared with the lower ubiquity value of $44.4 \%$ for maize. By site area, the two samples from Mound F had no maize remains, compared with $60 \%$ of the Southwest Village area samples, and $45.5 \%$ of the flotation samples from the Well Pad excavations.

Most of the maize consists of cob fragments: 2810 cupules or fragments thereof, some with glumes attached, and 246 separate glumes. In a few samples, several cupules along a row remain attached to each other, indicating that the archeological features originally contained whole cobs or at least more complete cob segments. No attempt was made to determine row number or "racial" characteristics. The shapes of these cupules vary from relatively wide and closed to narrow and open. Most of the glumes are impressively strong and durable. Although this assemblage is dominated by cob parts, it includes 18 kernel fragments.

Seeds were present in only three of the samples ( $16.7 \%$ ubiquity), with a total weight of $0.15 \mathrm{~g}$. Two relatively large persimmon seed fragments came from a heavy fraction of Feature 14. It is not impossible that these two fragments originally constituted one seed, but their condition is too poor to say for sure. One black, seemingly charred purslane seed was recovered from the light fraction of Feature 111. This seed might be a modern, uncarbonized contaminant, but without breaking it, its status remains in doubt. A few uncarbonized carpetweed seeds (Mollugo verticillata) were observed in other light fractions but this was the only purslane seed. Two unidentifiable charred seed fragments were found in the light fraction of Feature 12.

Unknowns make up a larger than usual part of the Hudnall-Pirtle archeobotanical assemblage, totaling 1085 fragments weighing $7.90 \mathrm{~g}$. The vast majority are probably pieces of wood, nutshell, and maize that are so heavily clay-encrusted or so badly damaged by the pebble-filled heavy fractions that recognition was unduly challenging, if not impossible. Animal bone occurred in seven (39.9\%) of the samples, with a total weight of $5.22 \mathrm{~g}$. Pieces of unworked stone, dried clay, and tiny pottery sherds and chert chips formed the bulk of all heavy fractions, with those larger than $2.0 \mathrm{~mm}$ weighing a total of $449.46 \mathrm{~g}$.

\section{Discussion}

Although the gravelly, clayey soils in the feature flotation samples impeded flotation recovery and probably lowered the diversity of the archeobotanical assemblage, it is nevertheless clear that Caddos at Hudnall-Pirtle practiced a mixed subsistence strategy combining maize agriculture with the harvesting of hickory nuts, acorn, and native fruits. The abundance of maize makes it unwise to minimize the economic significance of agriculture at this site, even though a less maize-dependent economy was expected for the relatively early Caddoan component (ca. A.D. 1000-1200). Maize comprises $84.8 \%$ of the weight of all food plants represented, although it is present in only $44.4 \%$ of the analyzed samples. Acorn shell and acorn meat contribute $7.9 \%$ of the total weight of food plants, and hickory nutshell comprises $6.8 \%$. This is very different from the nutshell-dominated assemblage from the Early Caddoan period Spoonbill site (41WD109), where hickory nutshell constituted $99.1 \%$ of the plant food remains by weight and where even acorn outweighed maize (Crane 1982; Perttula et al. 1982). It appears that either a far more agriculturally-oriented subsistence strategy was practiced at the Hudnall-Pirtle site, or else that there was a different seasonal or functional dimension to the occupation there. 
Due to the problematic flotation recovery that resulted in virtually sterile light fractions, little can be said about use of small seeds at Hudnall-Pirtle. Because $1.0 \mathrm{~mm}$ mesh rather than window screen (1.6 mm mesh) was used for heavy fraction recovery, numerous taxa of edible native seeds could have been retrieved, including sunflower (Helianthus annииs), sumpweed (Iva аппиа), various knotweeds and smartweeds (Polygonum spp.), and even the larger chenopods (Chenopodium spp.), had they been commonly used. To date, however, there is no evidence for serious use of starchy temperate seed crops such as Chenopodium berlanderi ssp. Jonesianum in northeastern Texas at any point in time. This distinguishes the southern Caddos from societies in the Arkansas River valley, such as those at Spiro and Toltec (Fritz 1989; Smith 1996), from groups in the Ozarks (Fritz 1986, 1994), and from peoples in the central Mississippi River valley (Fritz 1990; Johannessen 1993; Lopinot 1994).

\title{
THE FAUNAL REMAINS FROM THE HUDNALL-PIRTLE SITE (41RK4),
}

\author{
by Bonnie C. Yates
}

Only a small amount of faunal remains were recovered from the 1989-1990 excavations at the Hudnall-Pirtle site by the Texas Historical Commission. A total of 208 animal bones were recovered, primarily from the Southwest village area, along with a single possible human ulna from Unit 202 near Mound C (Table 13).

Of the faunal remains submitted for analysis, only deer (Odocoileus sp.) and indeterminate turtle were identified, while bison (Bison sp.) and human remains are suspected. At least two different turtles are represented, however, because of the presence of a large, thick-shelled specimen in the same provenience in the Southwest Village area (Unit 4, level 5) as a small, thin-shelled specimen. Referent taxa would be Chelydridae, or snapping turtles (large), and Kinosternidae, or mud turtles (small).

In Unit 16, level 4 (in the Southwest village area), elements of a right hind foot of a deer indicate a discarded ankle joint. It was probably articulated at the time of disposal. The pattern of calcination is consistent with bone that is burned while still fresh. No skinning or butchering cuts are apparent on these elements.

A carpal bone (right scaphoid) from a mammal larger than deer was recovered from Unit 201, level 4 (near Mound C, see Figure 2). The thin cortical bone of this specimen suggests that it is from an immature individual. It compares well with bison or elk in size and morphology.

The percentage of calcined bone in the sample is $73.5 \%$, which is extremely high. This indicates that the bone refuse was exposed to long periods of intense heat or direct fire. This probably resulted in total incineration of much of the faunal remains originally deposited by the site's occupants.

Two pieces of calcined long bone shaft fragments were found in Unit 202, level 4 (in a unit along the pipeline trench near Mound C) that resemble human ulna. They exhibit the typical u-shape cracks that result from intense firing of mammal long bones with flesh. No diagnostic features for Homo sapiens are present on the fragments, however, the surface texture and cracking is consistent for human remains that have been cremated.

The only other animals that could be present in this assemblage are medium-size mammals. Fragments of some of the long bone shafts are too small in diameter and bone wall thickness to be from deer. Unfortunately, no diagnostic morphology survived to indicate species for these specimens. 
Table 13. Inventory of Faunal Remains from the Hudnall-Pirtle site.

\begin{tabular}{|c|c|c|}
\hline Unit and Level & Count & Comments \\
\hline ST2 & 1 & $\begin{array}{l}\text { crushed long bone fragment } \\
\text { (B) }\end{array}$ \\
\hline ST4 & 3 & 1 deer petrous, 2 other $B$ \\
\hline ST8 & 1 & tooth fragment, cf. deer \\
\hline ST19 & 7 & LM fragments \\
\hline $4-5$ & 3 & all B; 1 large and small turtle \\
\hline $4-6$ & 3 & $\begin{array}{l}\text { all B; } 1 \text { crushed LM, } 2 \text { turtle } \\
\text { plastron fragments }\end{array}$ \\
\hline $6-3$ & 1 & tool fragment (B) \\
\hline 7-8 & 1 & $\begin{array}{l}\text { deer-size fragment; } 4 \text { UID } \\
\text { mussel shell fragments }\end{array}$ \\
\hline 7-9 & 1 & UID fragment (B) \\
\hline $7-10$ & 2 & UID fragments (B) \\
\hline $7-13$ & 1 & $\begin{array}{l}\text { deer-size long bone epiphysis } \\
\text { fragment (B) }\end{array}$ \\
\hline $13-0$ & 1 & MM long bone fragment (B) \\
\hline $13-2$ & 6 & $\begin{array}{l}1 \text { deer tarsal, } 5 \text { deer-size } \\
\text { naviculocuboid, tarsal) and } \\
\text { miscellaneous deer-size } \\
\text { fragments (all B) } \\
\text { fragments (all B) }\end{array}$ \\
\hline $13-4$ & 1 & turtle carapace fragment (B) \\
\hline $14-10$ & 3 & $\begin{array}{l}1 \text { deer-size vertebral } \\
\text { epiphysis, } 2 \text { LM fragments }\end{array}$ \\
\hline $14-12$ & 1 & UID fragment (B) \\
\hline $16-2$ & 1 & UID crushed fragment (B) \\
\hline $16-3$ & 1 & UID crushed fragment (B) \\
\hline $16-4$ & 15 & $\begin{array}{l}\text { pieces of } 1 \mathrm{rt} \text { hind foot of deer } \\
\text { (talus, calcaneum, }\end{array}$ \\
\hline $18-2$ & 1 & $\begin{array}{l}\text { deer-size tibia (proximal } \\
\text { fragment) }\end{array}$ \\
\hline $18-3$ & 1 & UID fragment (B) \\
\hline $18-4$ & 1 & $\begin{array}{l}\text { deer-size long bone fragment } \\
\text { (B) }\end{array}$ \\
\hline $19-4$ & 8 & $\begin{array}{l}1 \text { deer-size atlas, } 7 \text { UID } \\
\text { fragments }\end{array}$ \\
\hline $18 / 20-5$ & 11 & UID fragments (B) \\
\hline $20-4$ & 2 & UID fragments (B) \\
\hline $20-6$ & 1 & deer radius (rt proximal, $\mathrm{B}$ ) \\
\hline $21-3$ & 5 & UID fragments (B) \\
\hline $22-1$ & 2 & $\begin{array}{l}1 \text { deer naviculocuboid (lf } \\
\text { fragment), and } 1 \text { UID } \\
\text { fragment }\end{array}$ \\
\hline $23-1$ & 4 & UID fragments (B) \\
\hline $23-2$ & 2 & UID fragments (B) \\
\hline $107-6$ & 3 & UID fragments (B) \\
\hline $108-1$ & 1 & UID fragment (B) \\
\hline
\end{tabular}


Table 13. Inventory of Faunal Remains from the Hudnall-Pirtle site Continued.

\begin{tabular}{|c|c|c|}
\hline Unit and Level & Count & Comments \\
\hline $108-2$ & 1 & UID fragment (B) \\
\hline $112-2$ & 1 & UID fragment (B) \\
\hline $113-2$ & 1 & UID fragment (B) \\
\hline 117-1 & 2 & UID fragments (B) \\
\hline $118-1$ & 1 & UID fragment (B) \\
\hline $119-2$ & 5 & UID fragments (B) \\
\hline $121-2$ & 3 & UID fragments (B) \\
\hline $123-1$ & 1 & UID fragment (B) \\
\hline $123-2$ & 1 & UID fragment (B) \\
\hline $125-4$ & 1 & UID fragment (B) \\
\hline $129-3$ & 1 & UID fragment (B) \\
\hline $130-2$ & 1 & UID fragment (B) \\
\hline $133-2$ & 1 & $\begin{array}{l}\text { possible worked bone with } \\
\text { striae and abrasion (B) }\end{array}$ \\
\hline $137-2$ & 4 & UID fragments (B) \\
\hline $138-2$ & 2 & UID fragments (B) \\
\hline $140-2$ & 1 & UID fragment (B) \\
\hline $201-2$ & 3 & UID fragments \\
\hline $201-4$ & 1 & $\begin{array}{l}\text { cf. bison scaphoid (rt } \\
\text { immature) }\end{array}$ \\
\hline $201-6$ & 12 & deer-size fragments \\
\hline $202-4$ & 1 & $\begin{array}{l}\text { cf. human ulna (shaft pieces, } \\
\text { B) }\end{array}$ \\
\hline Feature 14 & 41 & $\begin{array}{l}1 \text { deer phalanx I (proximal } \\
\text { fragment), } 1 \text { deer metapodial } \\
\text { condyle, and } 39 \text { UID } \\
\text { fragments (all B) }\end{array}$ \\
\hline Feature 104, Zone 1 & 12 & $\begin{array}{l}1 \text { deer metapodial condyle, } 11 \\
\text { UID fragments (B) }\end{array}$ \\
\hline Feature 104, Zone 2 & 2 & UID fragments (B) \\
\hline Feature 107 & 2 & UID fragments (B) \\
\hline Feature 109 & 1 & UID fragment \\
\hline Feature 111, Zone 5 & 1 & UID fragment (B) \\
\hline Feature 114 & 3 & UID fragments (B) \\
\hline Mound $\mathrm{C}$, monitoring & 5 & $\begin{array}{l}\text { deer-size long bone shaft } \\
\text { fragments }\end{array}$ \\
\hline
\end{tabular}

Key to abbreviations: $\mathrm{B}=$ burned bone; $\mathrm{rt}=$ right; lf $=$ left; $\mathrm{LM}=$ large mammal; $\mathrm{MM}=$ medium mammal; UID $=$ unidentified 


\section{Summary and Discussion}

The Hudnall-Pirtle site (41RK4) - owned by The Archaeological Conservancy - is a major Early Caddoan period mound center on the Sabine River in the Pineywoods of northeastern Texas. The site has eight mounds of different sizes and shapes, three known borrow pits, and a large plaza around which the mounds are arranged (Figure 41). There are extensive habitation deposits associated with the use of the mounds and plaza, as they occur in a broad and large circular area outside of the plaza and away from the mounds. The habitation areas are marked by midden deposits as well as well-preserved features (pits and post holes), probably associated with domestic structures.

In 1989 and 1990, the Texas Historical Commission (THC) conducted archeological investigations at the HudnallPirtle site to assess the impact of oil development activities to the site, and also to gather information to support a National Register of Historic Places nomination. The work was concentrated in habitation deposits in different parts of the site-especially in the recently constructed Well Pad and in a habitation area called the Southwest Village-as well as in two of the mounds (Md. A and Md. F) (see Figure 2). The work documented the existence of midden deposits in the Southwest Village, and domestic habitation deposits and features now buried below the Well Pad. In the Md. F work, we documented that the small mound had been built over a burned structure, and the small southern extension to Md. A (see Figure 4) had been built over occupational deposits. The THC work also resulted in a topographic map of the site wchich depicted all of the site's earthen mounds. One activity was not accomplished from the THC planned work, as outlined in the "Introduction" to this article. This was the proposed Unit 9 to be placed in a large pothole in the center of Mound C. This unit is not shown on Figure 2, and was not completed due to the unconsolidated nature of the sands of the mound that kept collapsing during excavation. From the limited work in this area of the site, the entire fill of Mound $\mathrm{C}$ appears to be made up of yellow coarse sandy soil. However, more work in the mound is needed to verify this observation.

Over the course of the fieldwork and analysis we obtained four radiocarbon dates from Md. F and two features in the Well Pad. As a group, at 1 sigma, the calibrated age range of the four dates range from A.D. 980-1250, indicating an Early Caddoan period age for habitation and mound deposits at the eastern end of the HudnallPirtle site. Hopefully during future work at the site, more radiocarbon dates can be obtained from multiple contexts to reliably determine not only how long the prehistoric Caddo occupation lasted, as well as when it began and ended.

The recovered archeological materials from the village areas at the Hudnall-Pirtle site are consistent with the fact that a major Early Caddoan period occupation is present. The ceramics are dominated by sherds from vessels decorated with wet paste designs (78\%). Among these are vessels decorated with horizontal incised lines, free punctation, and zoned incised-punctated elements. These are from Davis Incised, Kiam Incised, Weches Fingernail Impressed, Crockett Curvilinear Incised, and Pennington Punctated-Incised types, all part of an Alto phase ceramic assemblage (cf. Story 2000:14). The wet paste decorated sherds include a few vessel sherds from Coles Creek, var. Coles Creek and var. Hardy vessels. These distinctive sherds are probably from vessels made in the lower Mississippi Valley (LMV), and are indicative of some form of contact and interaction between the Caddo living at Hudnall-Pirtle and contemporaneous Coles Creek populations in the LMV. These particular sherds may be the product of trade and exchange at a time of dynamic changes in Caddo and Coles Creek societies between ca. A.D. 900-1050.

The ceramic assemblage at Hudnall-Pirtle also has engraved fine wares from Hickory Engraved, Spiro Engraved, and Holly Fine Engraved types; sherds from these types comprise $22 \%$ of the decorated sherds. There are also a number of plain rims from many undecorated vessels in the ceramic assemblage. 
Based on differences in proportions of decorative methods represented in the decorated sherds, especially the percentage of incised sherds and the number of Coles Creek Incised sherds, it is possible that the earliest Caddo occupation took place in the Well Pad area, with later Caddo settlement better represented in the Southwest Village area. Whether there was a continuous occupation in all parts of the Hudnall-Pirtle site is still an open question, but the ceramic decorated sherd assemblage is suggestive of different occupational episodes at the site. It might also indicate that the construction and use of the mounds and plaza may be the result of a lengthy, but not necessarily continuous Caddo occupation throughout the early Caddoan period.

The lithic tool assemblage is dominated by unifacial expedient flake tools and arrow points, as well as grinding slabs and manos of moderate size. The different proportions of arrow point forms in the excavated areas suggest that the earliest use of the site took place in the Southwest Village area - the exact opposite of the decorated ceramic sherd evidence - as the Scallorn and Friley forms are found exclusively in the Southwest Village area.

From the recovered tools, cores, and lithic debris in village areas at Hudnall-Pirtle, the lithic technological strategy of the Caddo knappers was to reduce small pieces of local lithic raw materials to manufacture flake tools and smaller flake blanks for arrow points. Local cherts were the most common raw material in all the habitation areas, but non-local lithic raw materials are best represented in the Southwest Village area. These materials included novaculite and baked/fused cherts from the Manning Formation.

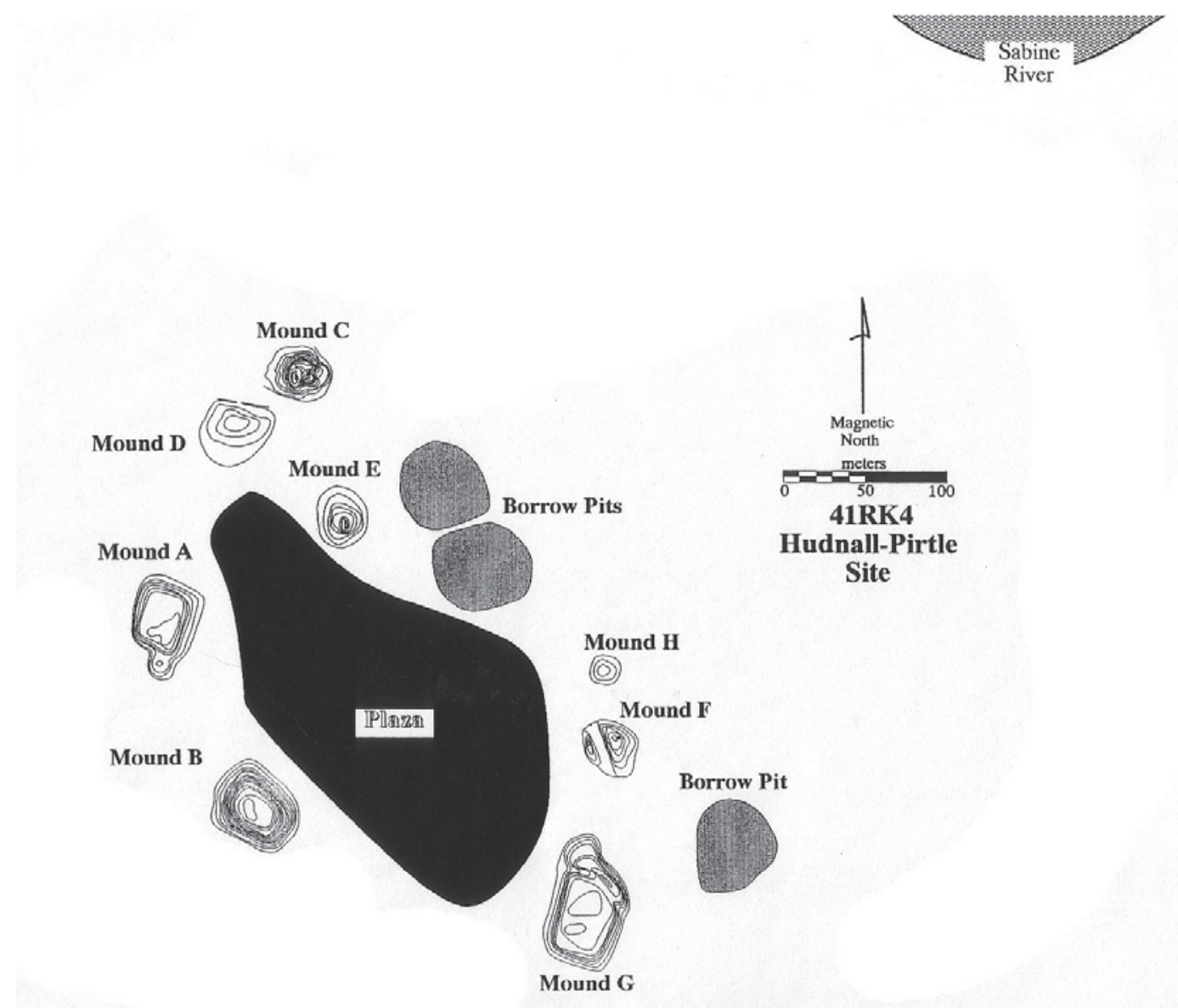

Figure 41. Plan of mounds, plaza, and borrow pits at the Hudnall-Pirtle site. 
The wide variety of chipped and ground stone tools recovered in habitation areas at Hudnall-Pirtle indicates that a diverse range of domestic tasks took place in each part of the site during the early Caddo occupation. These tasks apparently included hunting, game animal processing, stone tool production, and the processing of gathered and cultivated plant foods.

Subsistence remains recovered in the habitation archeological deposits include large game animals (deer and bison) and turtles, as well as various plant remains. The plant remains are dominated by maize, a tropical cultigen, ands nutshells (from the gathering of hardwood mast), and a few seeds (of persimmon and purslane). The maize ubiquity in the flotation samples from features is $44 \%$, suggesting that the cultivation of maize was part of a low-level food-producing society (cf. Smith 2001).

The Hudnall-Pirtle site during the Early Caddoan period occupation was clearly an important civic-ceremonial center, certainly the premier mound complex in the Sabine River basin of northeastern Texas. Story (2000:23) suggests it may have been a Caddo center of great regional importance. This may well be the case, but its full importance during the ca. A.D. 1000-1200 period will not be recognized or understood until further studies of the major mounds and extensive village deposits can be conducted. When was the early Caddo settlement established at Hudnall-Pirtle, and how did the mound center develop through time with respect to community organization and inter-relationships, mortuary behavior, and material culture changes? These questions are just the tip of the iceberg in terms of what it will be important to know about the origins and development of Caddo native history at this important place. Until such time as concerted and detailed archeological investigations can take place at the Hudnall-Pirtle site, it is good to realize that the site is being effectively protected and preserved by The Archaeological Conservancy.

\section{ACKNOWLEDGMENTS}

Perttula would like to thank Kathy Roemer for preparing the many lithic artifact illustrations that accompany this manuscript, and thanks also to Roland Pantermuehl for his help with figure production. He would also like to thank Gayle Fritz and Bonnie C. Yates for conducting the analyses of plant and animal remains found at the Hudnall-Pirtle site. The funds for the radiocarbon dates were provided by the Texas Historical Commission (THC) and Archeological \& Environmental Consultants, LLC.

Those people who worked at Hudnall-Pirtle in 1989 includes: James Bruseth, Wayne Batholomew, Jan Murray, Bill Martin, Deborah Smith, Dan Prikryl, Nancy Kenmotsu, and Bob Turner. During the 1990 work, there were many volunteers along with THC employees: Nancy Kenmotsu, Bill Martin, Jan Murray, Dan Prikryl, Tim Perttula, James Bruseth, Deborah Smith, Bo Nelson, Bob Turner, Bob Skiles, Paul Lorrain, Jan Lorrain, Nelson Cowles, Russell Poole, Bill Bourne, Anne-Marie Durham, Melissa Higgins, Carl P. Venzke, W. T. Lerke, Jim Warren, Joyce Warren, Donald P. Duncan, Jr., Brenda Whorton, Debra Daugherty, Jim Clemens, Louis Baker, John Conners, Marshall McIntosh, Ann Rhodes, Ray Hubbard, William Fields, Dee Bishop, Giselle Ellis, Brian Babin, Leif Babin, Mike Alford, Mike Allen, Norman Black, Jack Keller, Bonnie McKee, Tom Middlebrook. Virginia Long, David Nicklaw, Darrell Thompson, Mike Patton, and George Shannon. 


\section{REFERENCES CITED}

Abbott, A. L., R. D. Leonard, and G. T. Jones

1998 Explaining the Change from Biface to Flake Technology: A Selectionist Application. In Darwinian Archaeologies, edited by H. Donald, G. Maschner, and S. Shennan, pp. 33-43. Plenum Press, New York.

Bomar, G. W.

1983 Texas Weather. University of Texas Press, Austin.

Brown, J. A.

1996 The Spiro Ceremonial Center: The Archaeology of the Arkansas Valley Caddoan Cultures in Eastern Oklahoma. 2 Vols. Memoirs of the Museum of Anthropology, University of Michigan, Number 29, Ann Arbor.

Brown, K. M.

1976 Fused Volcanic Glass from the Manning Formation. Bulletin of the Texas Archeological Society 47:189-207.

Bruseth, J. E.

1991 Hudnall-Pirtle Site: An Early Caddoan Mound Complex in Northeast Texas. Caddoan Archeology Newsletter II(3):9-15.

Bruseth, J. E. and T. K. Perttula

1981 Prehistoric Settlement Patterns at Lake Fork Reservoir. Texas Antiquities Permit Series, Report No. 2. Texas Antiquities Committee and Southern Methodist University, Austin and Dallas.

Collins, M. B. and C. B. Bousman

1993 Quaternary Environments and Archeology in Northeast Texas. In Archeology in the Eastern Planning Region, Texas: A Planning Document, edited by N. A. Kenmotsu and T. K. Perttula, pp. 49-67. Cultural Resource Management Report 3. Department of Antiquities Protection, Texas Historical Commission, Austin.

Crane, C. J.

1982 Plant Utilization at Spoonbill, an early Caddoan Site in Northeast Texas. Midcontinental Journal of Archaeology 7:81-97.

Davis, H. A., D. G. Wyckoff, and M. A. Holmes (editors)

1971 Proceedings of the Seventh Caddo Conference. Oklahoma Archeological Survey, Occasional Publications Number 1 , Norman.

Frederick, C. D., M. D. Glascock, H. Neff, and C. M. Stevenson

1994 Evaluation of Chert Patination as a Dating Technique: A Case Study from Fort Hood, Texas. Archeological Resource Management Series, Research Report No. 32. United States Army Fort Hood.

Fritz, G. J.

1986 Prehistoric Ozark Agriculture: The University of Arkansas Rockshelter Collections. Ph.D. dissertation, Department of Anthropology, University of North Carolina at Chapel Hill

1989 Evidence of Plant Use from Copple Mound at the Spiro Site. In Contributions to Spiro Archaeology: Mound Excavations and Regional Perspectives, edited by J. D. Rogers, D. G. Wyckoff, and D. A. Peterson, pp. 65-87. Studies in Oklahoma's Past No. 16. Oklahoma Archeological Survey, Norman.

1990 Multiple Pathways to Farming in Precontact Eastern North America. Journal of World Prehistory 4:387-435.

1994 In Color and In Time: Prehistoric Ozark Agriculture. In Agricultural Origins and Developments in the Midcontinent, edited by W. Green, pp. 105-126. Report 19. Office of the State Archaeologist, University of Iowa, Iowa City.

Girard, J. S.

1994 Investigations at the James Pace Site (16DS268), DeSoto Parish, Louisiana. Caddoan Archeology Newsletter $\mathrm{V}(1): 8-16$. 
Griffith, K.

2001 Soil Survey of Rusk County, Texas. United States Department of Agriculture, Natural Resources Conservation Service, in cooperation with the Texas Agricultural Experiment Station and Texas State Soil and Water Conservation Board.

Hoffman, M. P.

1967 Ceramic Pipe Style Chronology Along the Red River Drainage in Southwestern Arkansas. The Arkansas Archeologist 8(1):4-14.

Jensen, H. P.

1968 Archaeological Investigations in the Toledo Bend Reservoir: 1966-1967. Archaeology Salvage Project, Southern Methodist University, Dallas.

Johannessen, S.

1993 Farmers of the Late Woodland. In Foraging and Farming in the Eastern Woodlands, edited by C. M. Scarry, pp. 57-77. University Press of Florida, Gainesville.

Jordan, T. G., J. L. Bean, Jr., and W. M. Holmes

1984 Texas: A Geography. Westview Press, Boulder.

Lopinot, N. H.

1994 A New Crop of Data on the Cahokian Polity. In Agricultural Origins and Developments in the Midcontinent, edited by W. Green, pp. 127-153. Report 19. Office of the State Archaeologist, University of Iowa, Iowa City.

McGimsey, C. R. and J. van der Koogh

2001 Louisiana's Archaeological Radiometric Database. Special Publication No. 3. Louisiana Archaeological Society, Baton Rouge.

Newell, H. P. and A. D. Krieger

1949 The George C. Davis Site, Cherokee County, Texas. Memoir No. 5. Society for American Archaeology and The University of Texas, Menasha, Wisconsin.

Perttula, T. K.

1984 Patterns of Prehistoric Lithic Raw Material Utilization in the Caddoan Area: Western Gulf Coastal Plain. In Prehistoric Chert Exploitation: Studies from the Mid-Continent, edited by B. M. Butler and E. E. May, pp. $129-148$. Occasional Paper 2. Center for Archaeological Investigations, Southern Illinois University at Carbondale.

1998 A Compendium of Radiocarbon and Oxidizable Carbon Ratio Dates from Archaeological Sites in East Texas, with a discussion of the Age and Dating of Select Components and Phases. Radiocarbon 39(3):305-342.

Perttula, T. K. and B. Nelson

2004 Woodland and Caddo Archeology at the Broadway or Kanduts'ah Kuhnihdahahdisa' Site (41SM273) on the City of Tyler-Lake Palestine WTP Project, Smith County, Texas. Report of Investigations No. 50. Archeological \& Environmental Consultants, LLC, Austin.

Perttula, T. K., C. J. Crane, and J. E. Bruseth

1982 A Consideration of Caddoan Subsistence. Southeastern Archaeology 1 (2):89-102.

Perttula, T. K., D. E. Wilson, and M. Walters

2000 An Early Caddoan Period Cremation from the Boxed Springs Mound Site (41UR30) in Upshur County, Texas, and a Report on Previous Archaeological Investigations. Journal of Northeast Texas Archaeology 12:31-71.

Phillips, P.

1970 Archaeological Survey in the Lower Yazoo Basin, Mississippi, 1949-1955. Papers of the Peabody Museum of Archaeology and Ethnology, Harvard University, Volume 60, Part One. Harvard University, Cambridge.

Prewitt, E. R.

1995 Distribution of Typed Projectile Points in Texas. Bulletin of the Texas Archeological Society 66:83-173.

Rogers, R., M. A. Nash, and T. K. Perttula

2001 Excavations at the Herman Bellew Site (41RK222), Rusk County, Texas. Document No. 000021. PBS\&J, Austin. 
Shafer, H. J.

1973 Lithic Technology at the George C. Davis Site, Cherokee County, Texas. Ph.D. dissertation, Department of Anthropology, The University of Texas at Austin.

2005 People of the Prairie: A Possible Connection to the Davis Site Caddo. MS on file, Texas Department of Transportation, Environmental Affairs Division, Archeological Studies Program.

Smith, B. D.

2001 Low Level Food Production. Journal of Archaeological Research 9:1-43.

Smith, C.

1996 Analysis of Plant Remains from Mound S at the Toltec Site. The Arkansas Archeologist 35:51-76.

Stokes, J. and J. L. Woodring

1981 Native-Made Artifacts of Clay. In Archeological Investigations at the George C. Davis Site, Cherokee County, Texas: Summers of 1979 and 1980, edited by D. A. Story. Texas Archeological Research Laboratory Occasional Papers, Number 1, University of Texas, Austin.

Story, D. A.

1990 Cultural History of the Native Americans. In The Archeology and Bioarcheology of the Gulf Coastal Plain, by D. A. Story, J. A. Guy, B. A. Burnett, M. D. Freeman, J. C. Rose, D. G. Steele, B. W. Olive, and K. J. Reinhard, pp. 163-366. Research Series No. 38. 2 Vols. Arkansas Archeological Survey, Fayetteville.

2000 Introduction. In The George C. Davis Site, Cherokee County, Texas, by H. P. Newell and A. D. Krieger, pp. 1-31. 2nd Edition. Society for American Archaeology, Washington, D.C.

Story, D. A. (editor)

1981 Archeological Investigations at the George C. Davis Site, Cherokee County, Texas: Summers 1979 and 1980. Occasional Papers, Vol. 1. Texas Archeological Research Laboratory, The University of Texas at Austin.

Suhm, D. A. and E. B. Jelks (editors)

1962 Handbook of Texas Archaeology: Type Descriptions. Special Publication Number 1, Texas Archeological Society, and Bulletin 4, Texas Memorial Museum, Austin.

Tomka, S. A.

2001 The Effect of Processing Requirements on Reduction Strategies and Tool Form: A New Perspective. In Lithic Debitage: Context, Form, Meaning, edited by W. Andrefsky, Jr., pp. 207-223. University of Utah Press, Salt Lake City.

Turner, R. L. and J. E. Smith

2003 The Harold Williams Site (41CP10) and the Texas Archeological Society Field School of 1967. Bulletin of the Texas Archeological Society 73:1-68.

Walters, $\mathrm{M}$.

2004 41SM195A, The Browning Site. Caddoan Archeology Journal 13 (3/4):19-20.

2005 A Profile in East Texas Archeology. Bulletin of the Texas Archeological Society 75:119-120.

Webb, C. H.

1963 The Smithport Landing Site: An Alto Focus Component in De Soto Parish, Louisiana. Bulletin of the Texas Archeological Society 34:143-187.

Webb, C. H. and R. R. McKinney

1975 Mounds Plantation (16CD12), Caddo Parish, Louisiana. Louisiana Archaeology 2:39-127.

Woldert, William Albert, Sr.

1932 East Texas. Unpublished manuscript on file at the Tyler Public Library, Tyler, Texas.

Woosley, A.M.

1939 Notes on file at the Texas Archeological Research Laboratory, The University of Texas at Austin. 
Appendix 1,

Radiocarbon Data Forms from the Hudnall-Pirtle Site (41RK4)

\section{CALIBRATION OF RADIOCARBON AGE TO CALENDAR YEARS}

(Variables: $\mathrm{C} 13 / \mathrm{C} 12=-8.7:$ lab. mult=1)

Laboratory number: Beta-129982

Conventional radiocarbon age: $330 \pm 110 \mathrm{BP}$

2 Sigma calibrated results: Cal AD 1410 to 1700 (Cal BP 540 to 250) and

(95\% probability) Cal AD 1720 to 1820 (Cal BP 230 to 130 ) and

Cal AD 1835 to 1880 (Cal BP 115 to 70 ) and

Cal AD 1915 to 1950 (Cal BP 35 to 0)

Intercept data

Intercepts of radiocarbon age with calibration curve:

Cal AD 1520 (Cal BP 430) and

Cal AD 1575 (Cal BP 375) and

Cal AD 1625 (Cal BP 325)

1 Sigma calibrated results: Cal AD 1445 to 1660 (Cal BP 505 to 290)

(68\% probability)

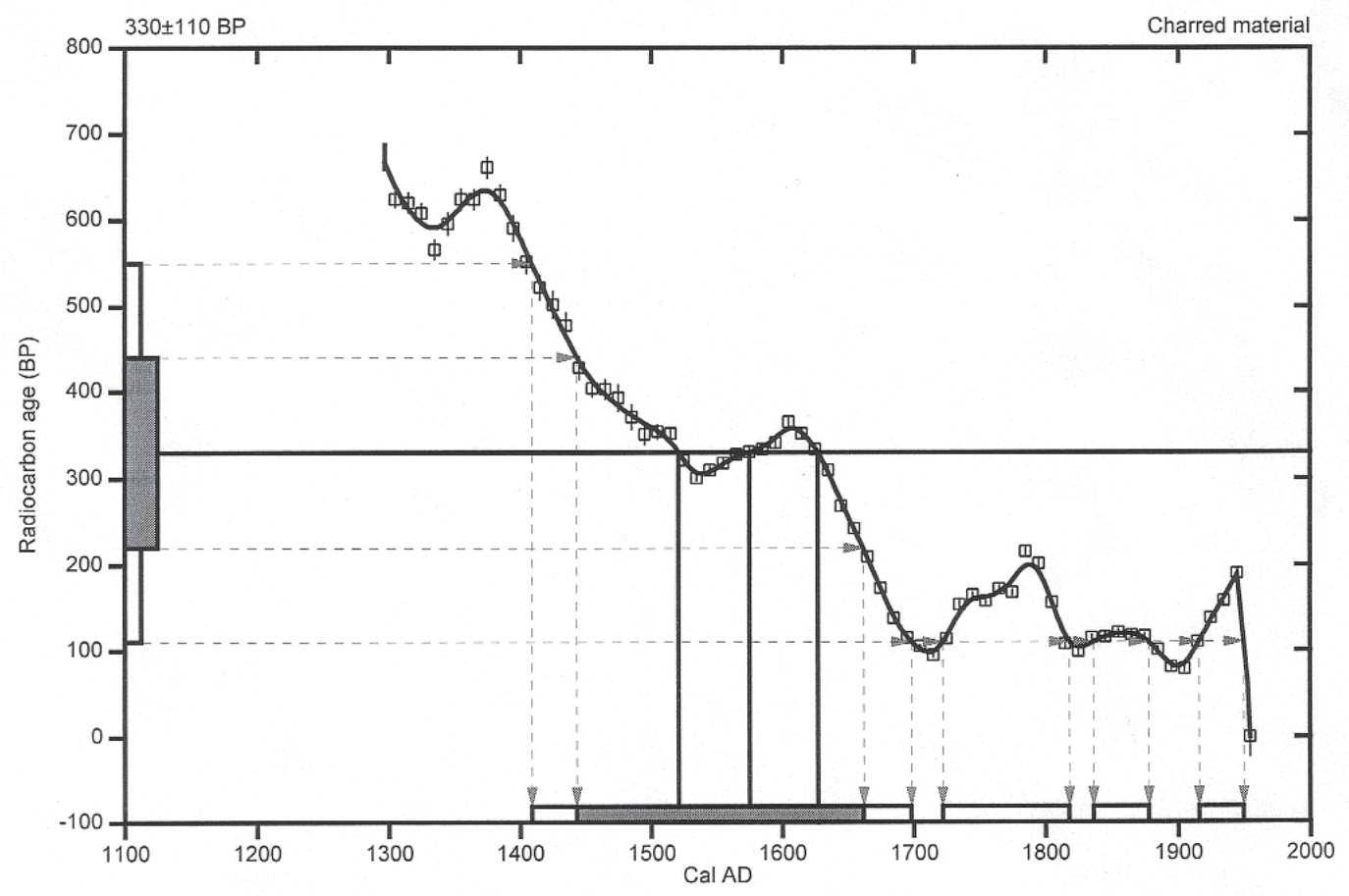

References:

Database used
INTCAL98

Calibration Database

Editorial Comment

Stuiver, M., van der Plicht, H., 1998, Radiocarbon 40(3), pxii-xiii

INTCAL98 Radiocarbon Age Calibration

Stuiver, M., et. al., 1998, Radiocarbon 40(3), p1041-1083

Mathematics

A Simplified Approach to Calibrating C14 Dates

Talma, A. S., Vogel, J. C., 1993, Radiocarbon 35(2), p317-322

\section{Beta Analytic Radiocarbon Dating Laboratory}

4985 S.W. 74th Court, Miami, Florida 33155 •Tel: (305)667-5167 • Fax: (305)663-0964 • E-mail: beta@radiocarbon.com 


\section{CALIBRATION OF RADIOCARBON AGE TO CALENDAR YEARS}

(Variables: C13/C12=-9.4:lab. mult=1)

Laboratory number: Beta-129983

Conventional radiocarbon age: $\mathbf{9 5 0 \pm 7 0 ~ B P}$

2 Sigma calibrated result: Cal AD 980 to 1235 (Cal BP 970 to 715)

(95\% probability)

Intercept data

Intercept of radiocarbon age

with calibration curve:

1 Sigma calibrated result: Cal AD 1010 to 1175 (Cal BP 940 to 775 )

(68\% probability)

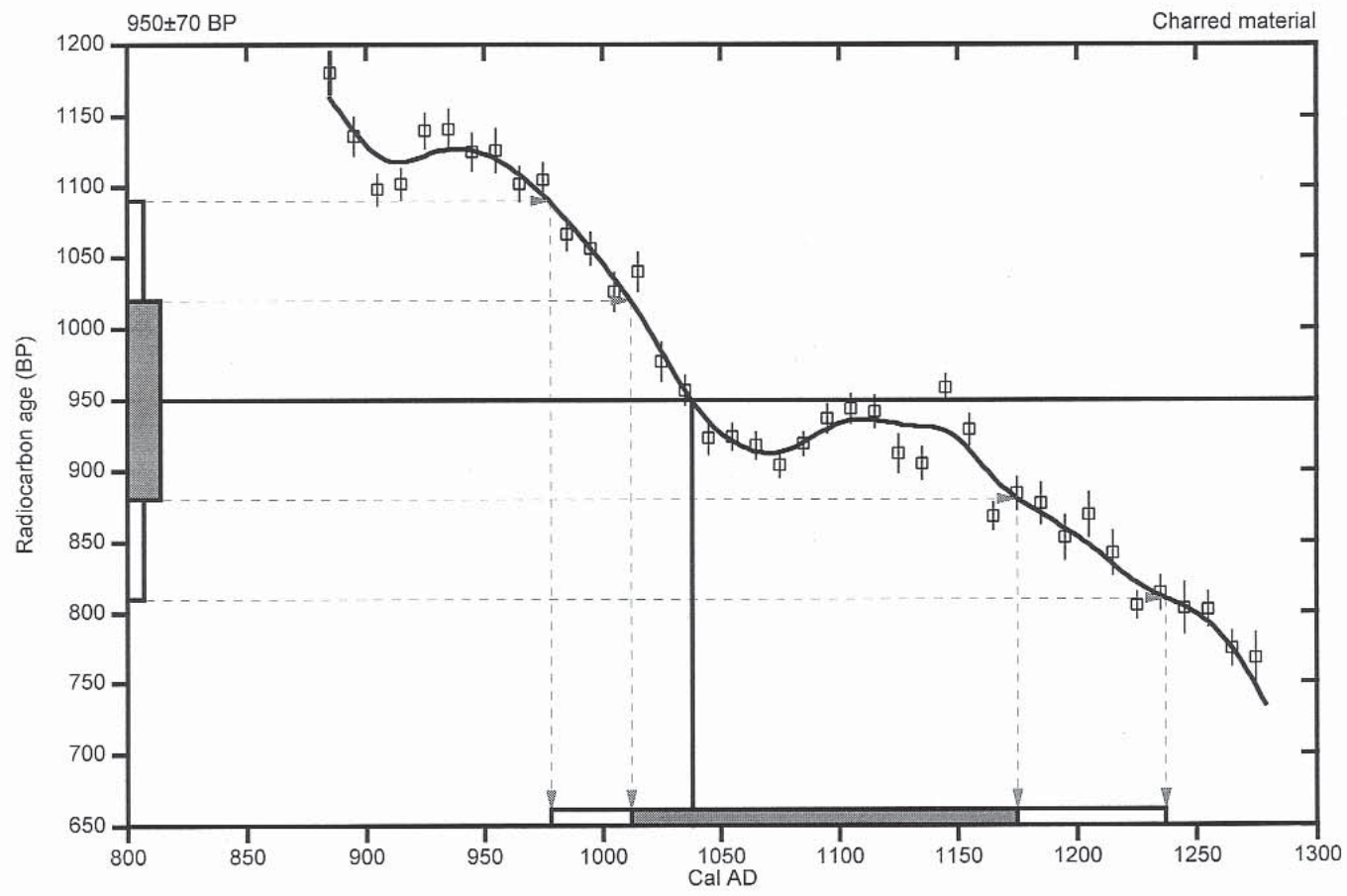

References:

Database used

$$
\text { INTCAL98 }
$$

Calibration Database

Editorial Comment

Stuiver, M., van der Plicht, H., 1998, Radiocarbon 40(3), pxii-xiii

INTCAL 98 Radiocarbon Age Calibration

Stuiver, M., et. al., 1998, Radiocarbon 40(3), p1041-1083

Mathematics

A Simplified Approach to Calibrating C14 Dates

Talma, A. S., Vogel, J. C., 1993, Radiocarbon 35(2), p317-322

\section{Beta Analytic Radiocarbon Dating Laboratory}

4985 S.W. 74th Court, Miami, Florida 33155 Tel: (305)667-5167 • Fax: (305)663-0964•E-mail: beta@radiocarbon.com 


\section{CALIBRATION OF RADIOCARBON AGE TO CALENDAR YEARS}

(Variables: $\mathrm{C} 13 / \mathrm{C} 12=-10.1$ :lab. mult=1)

Laboratory number: Beta-129984

Conventional radiocarbon age: $890 \pm 60 \mathrm{BP}$

2 Sigma calibrated result: Cal AD 1015 to 1265 (Cal BP 935 to 685)

( $95 \%$ probability)

Intercept data

Intercept of radiocarbon age

with calibration curve: $\mathrm{Cal}$ AD 1170 (Cal BP 780)

1 Sigma calibrated result: $\mathrm{Cal}$ AD 1040 to 1220 (Cal BP 910 to 730)

( $68 \%$ probability)

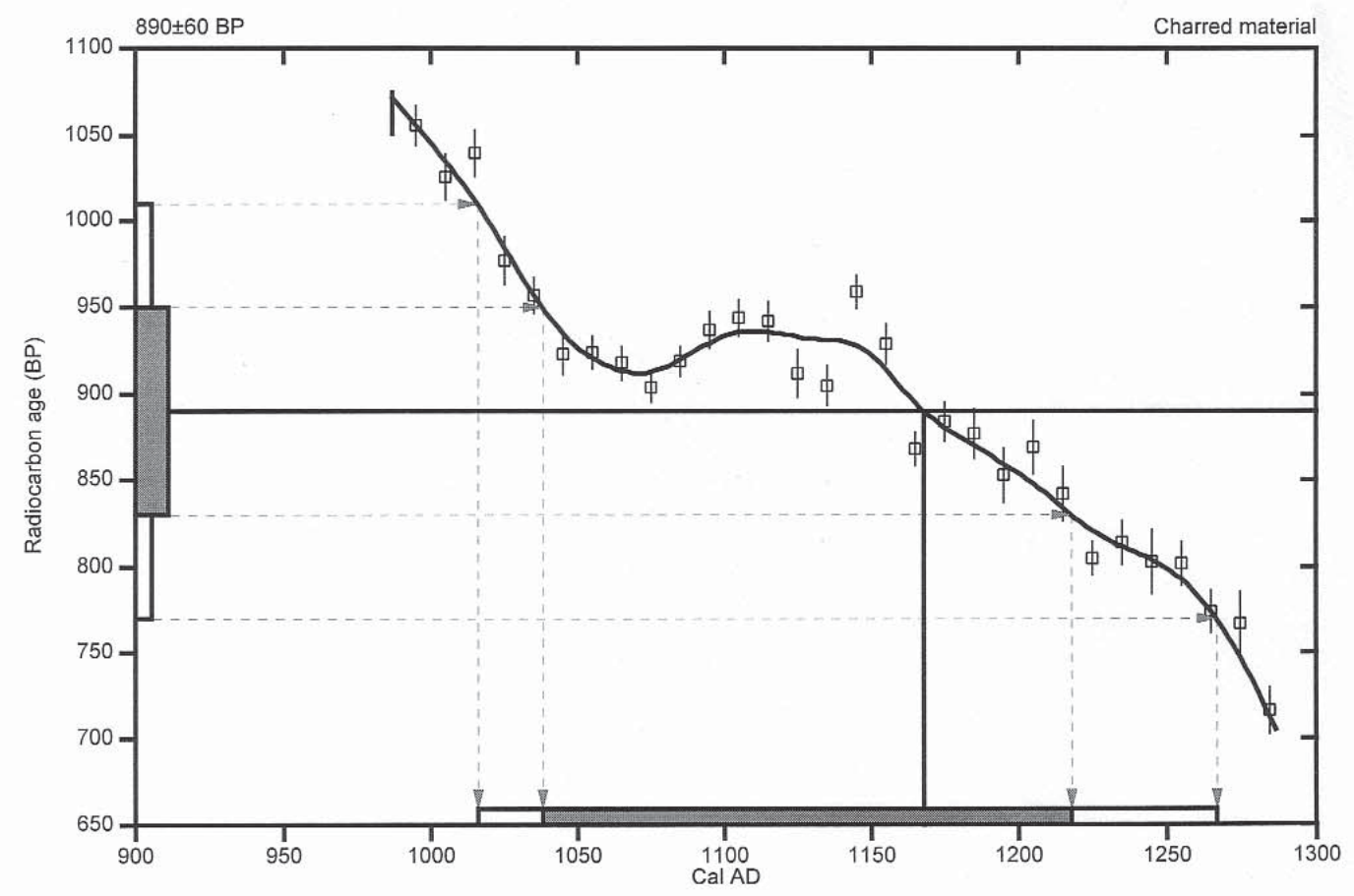

References:

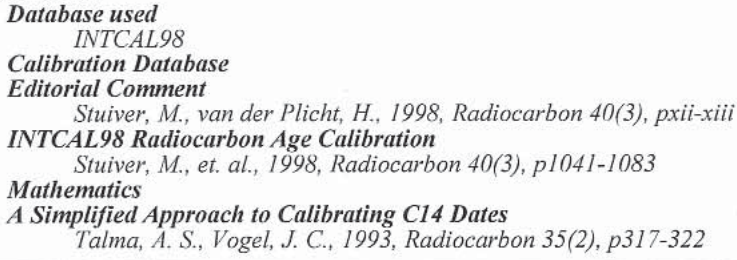

\section{Beta Analytic Radiocarbon Dating Laboratory}

4985 S.W. 74th Court, Miami, Florida 33155 - Tel: (305)667-5167 • Fax: (305)663-0964 - E-mail: beta@radiocarbon.com 
Appendix 2,

Vessel Sherds from the Hudnall-Pirtle Site, by James E. Bruseth

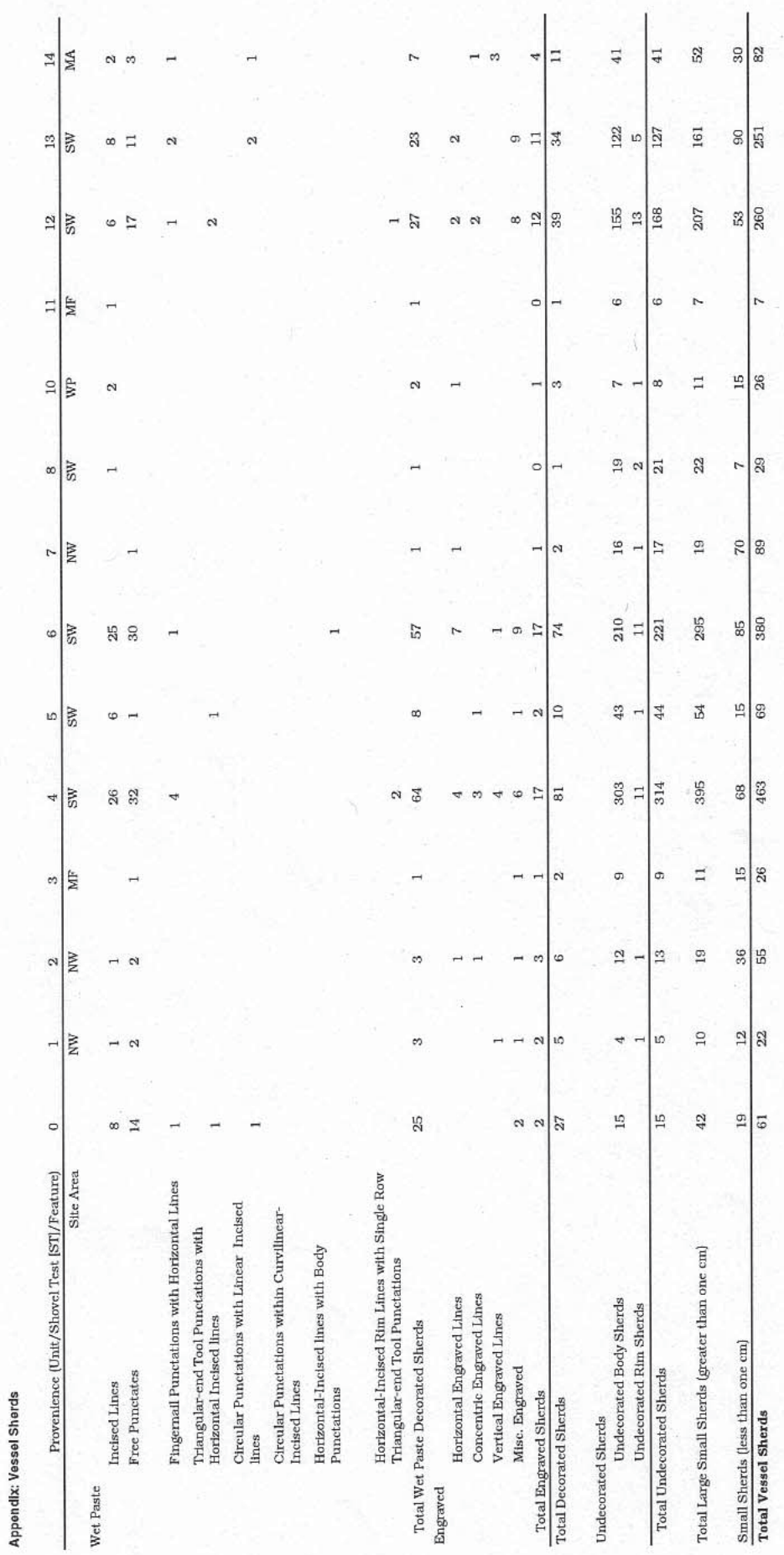




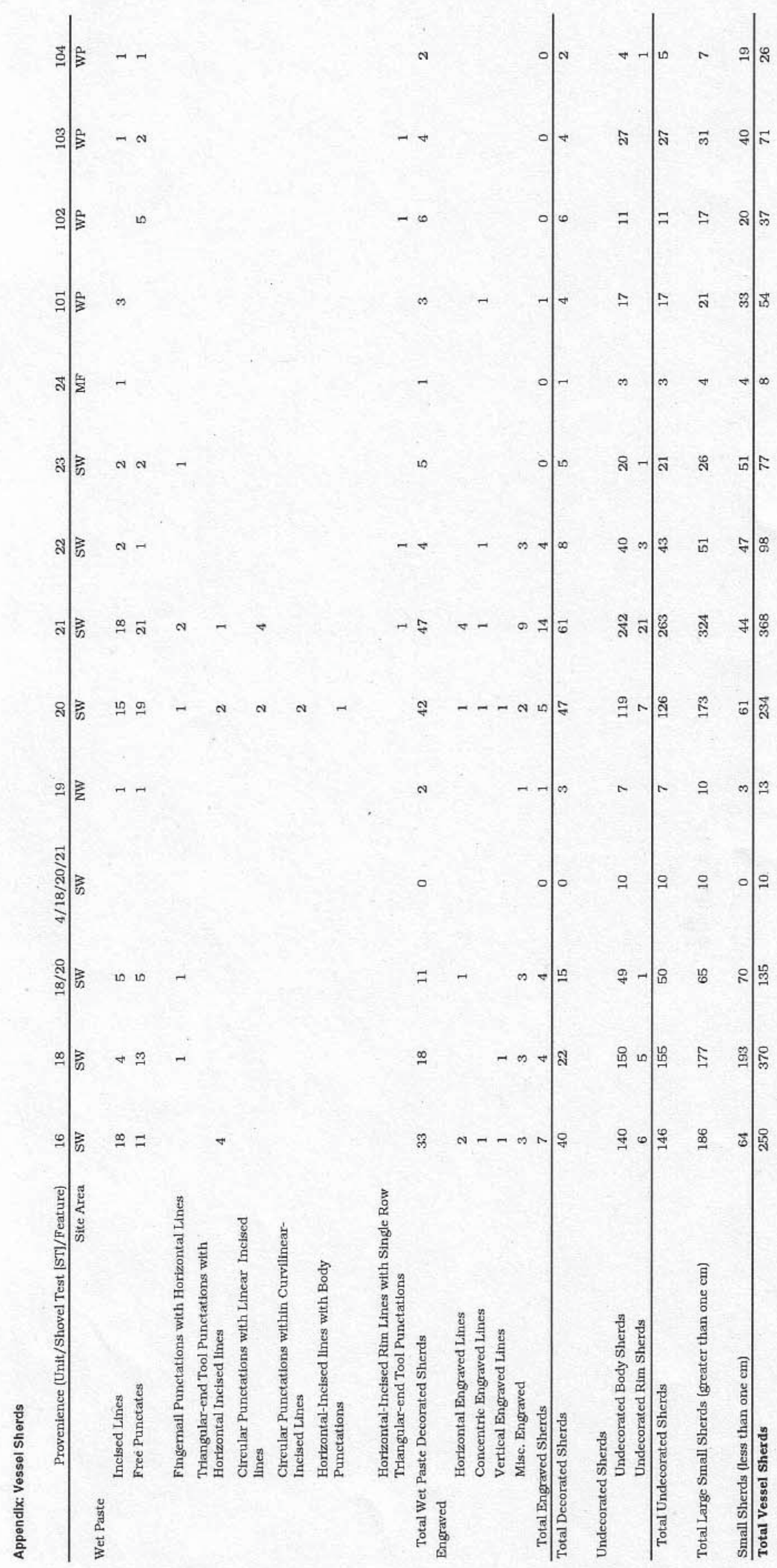




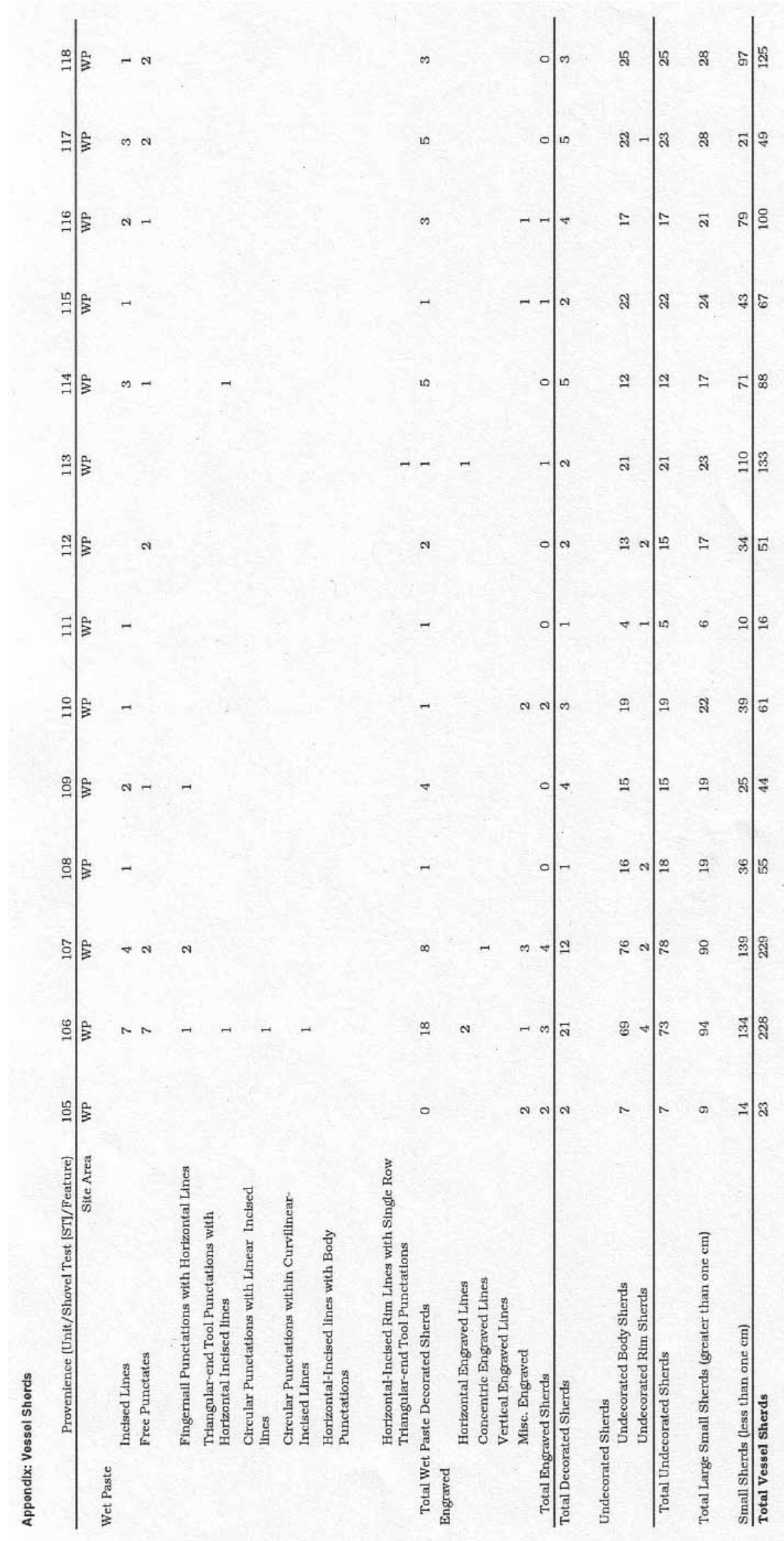




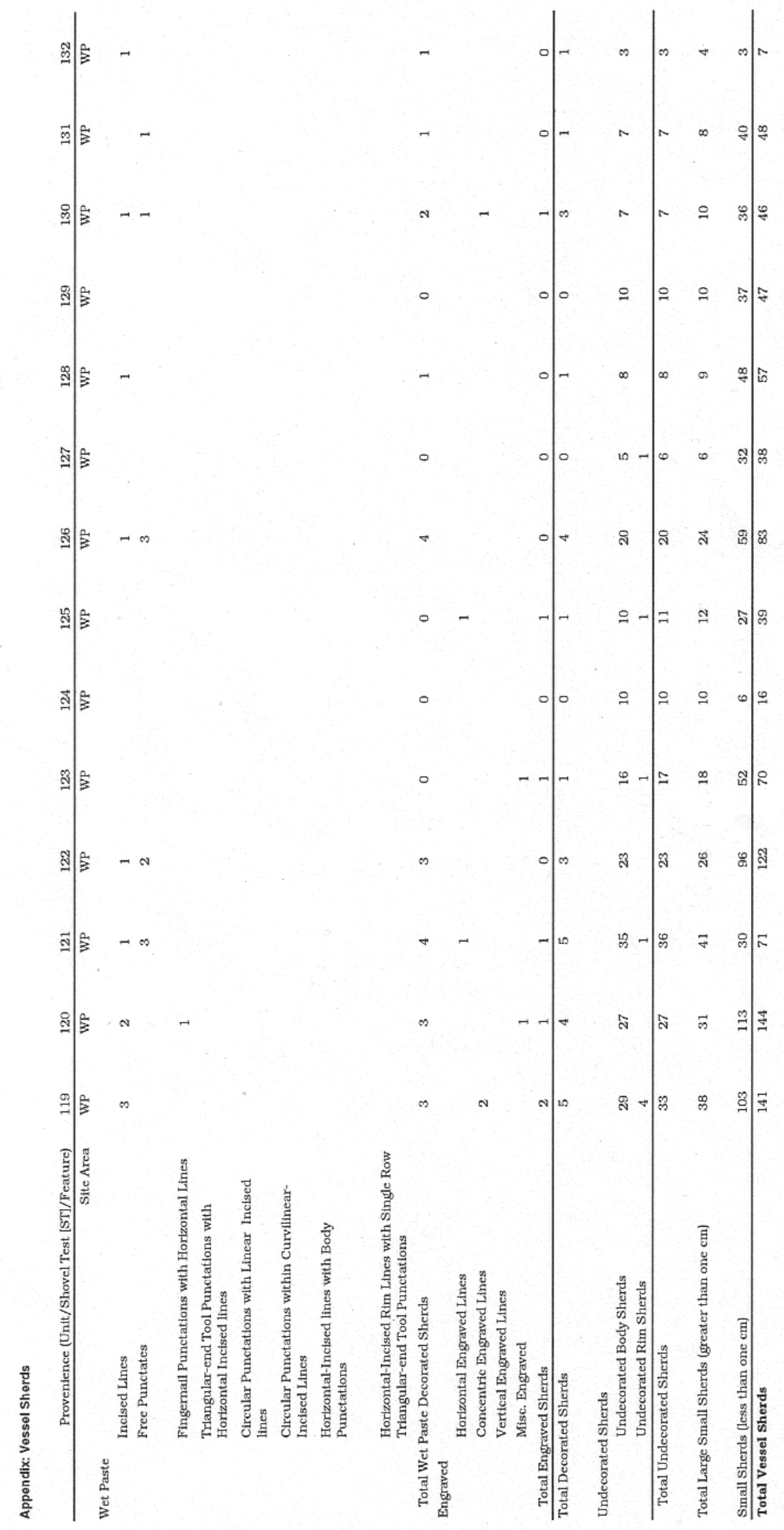




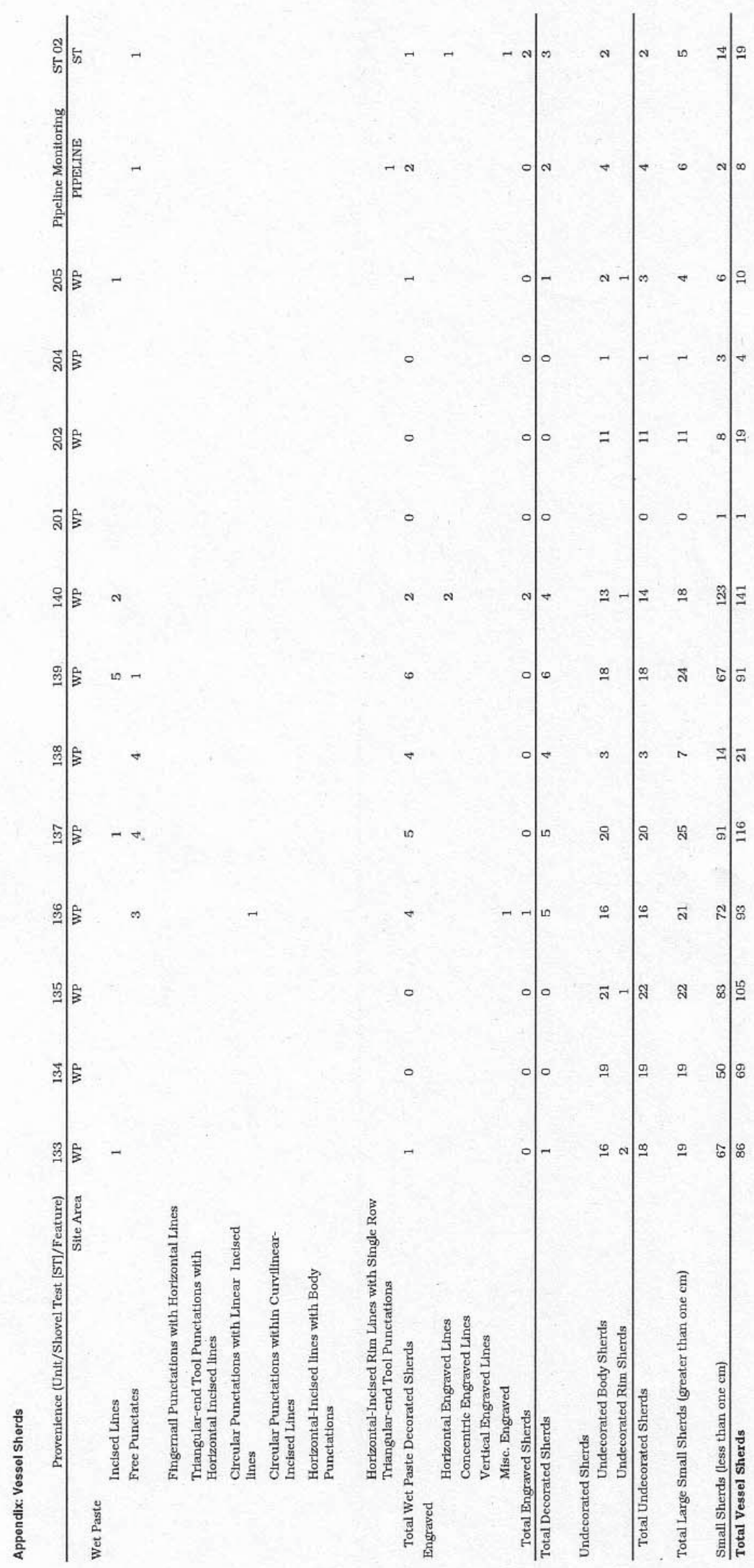




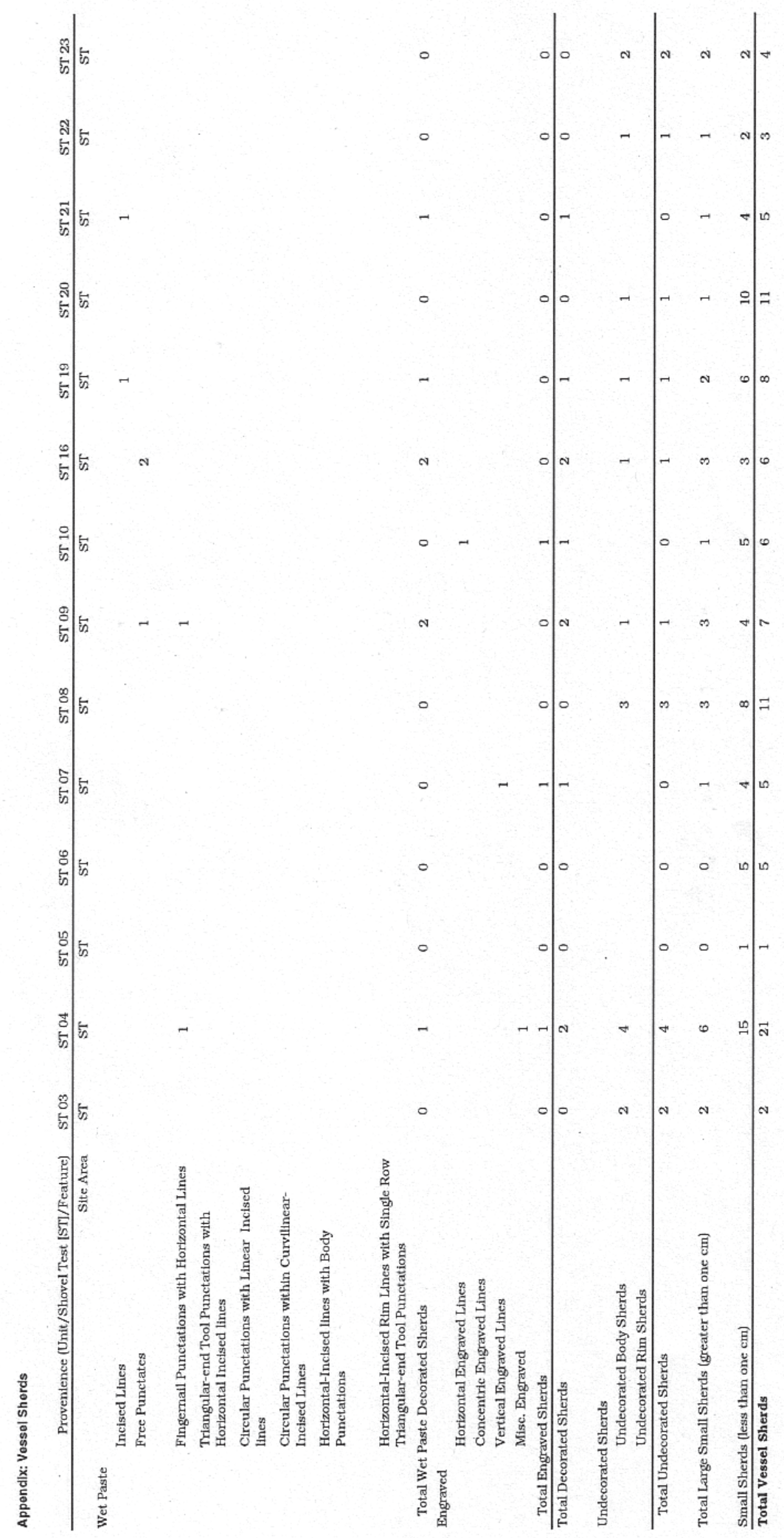




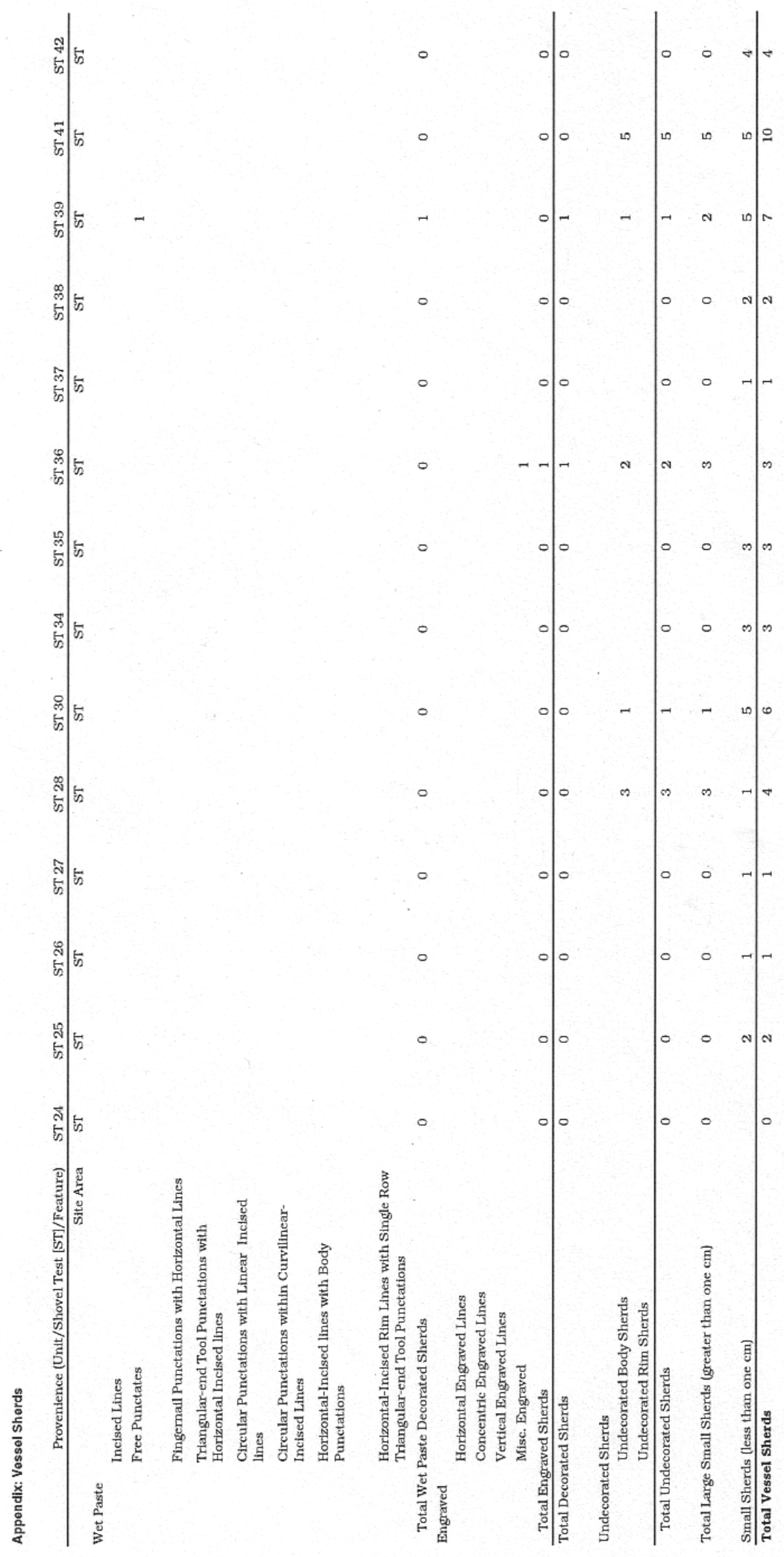




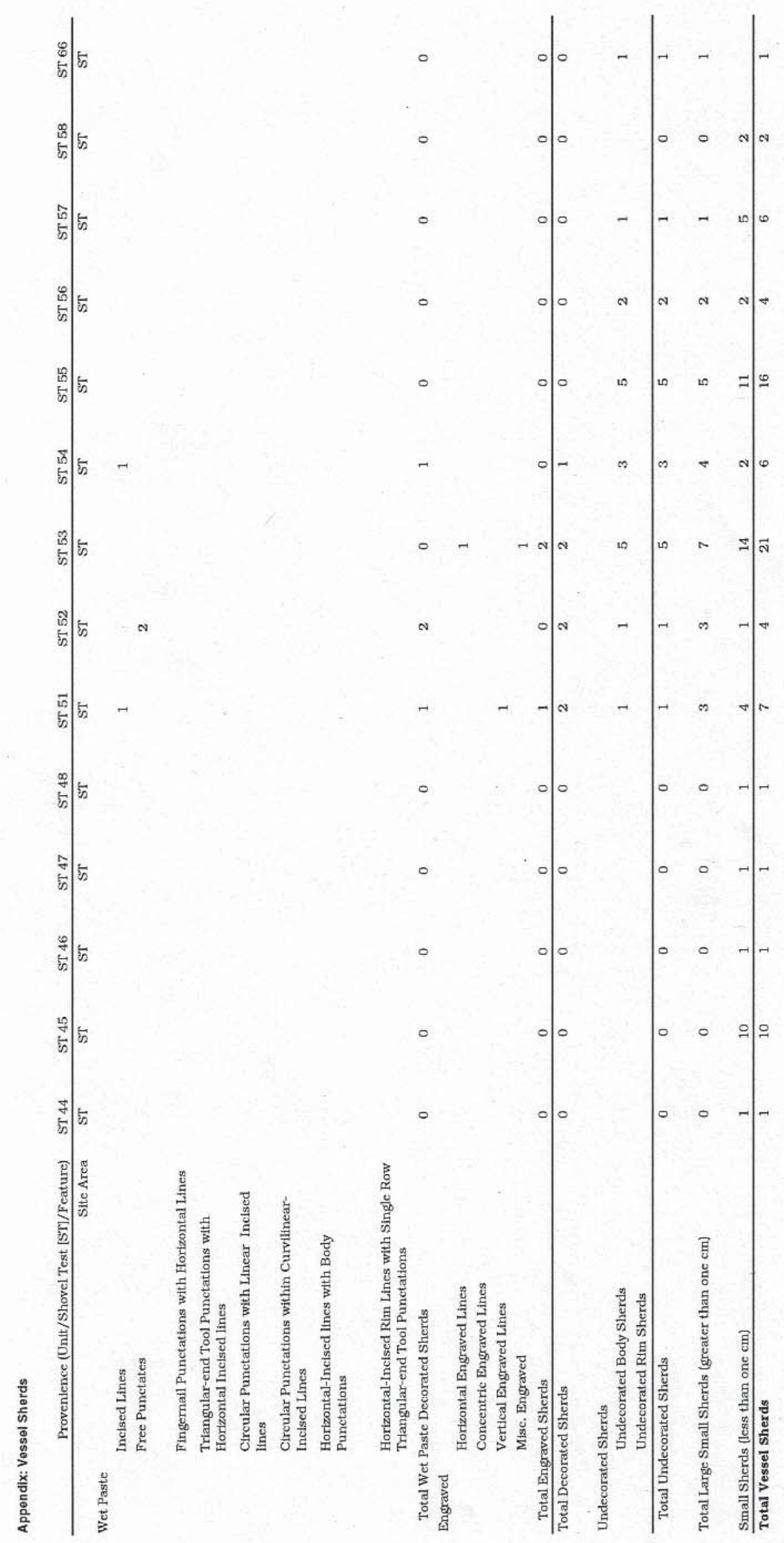




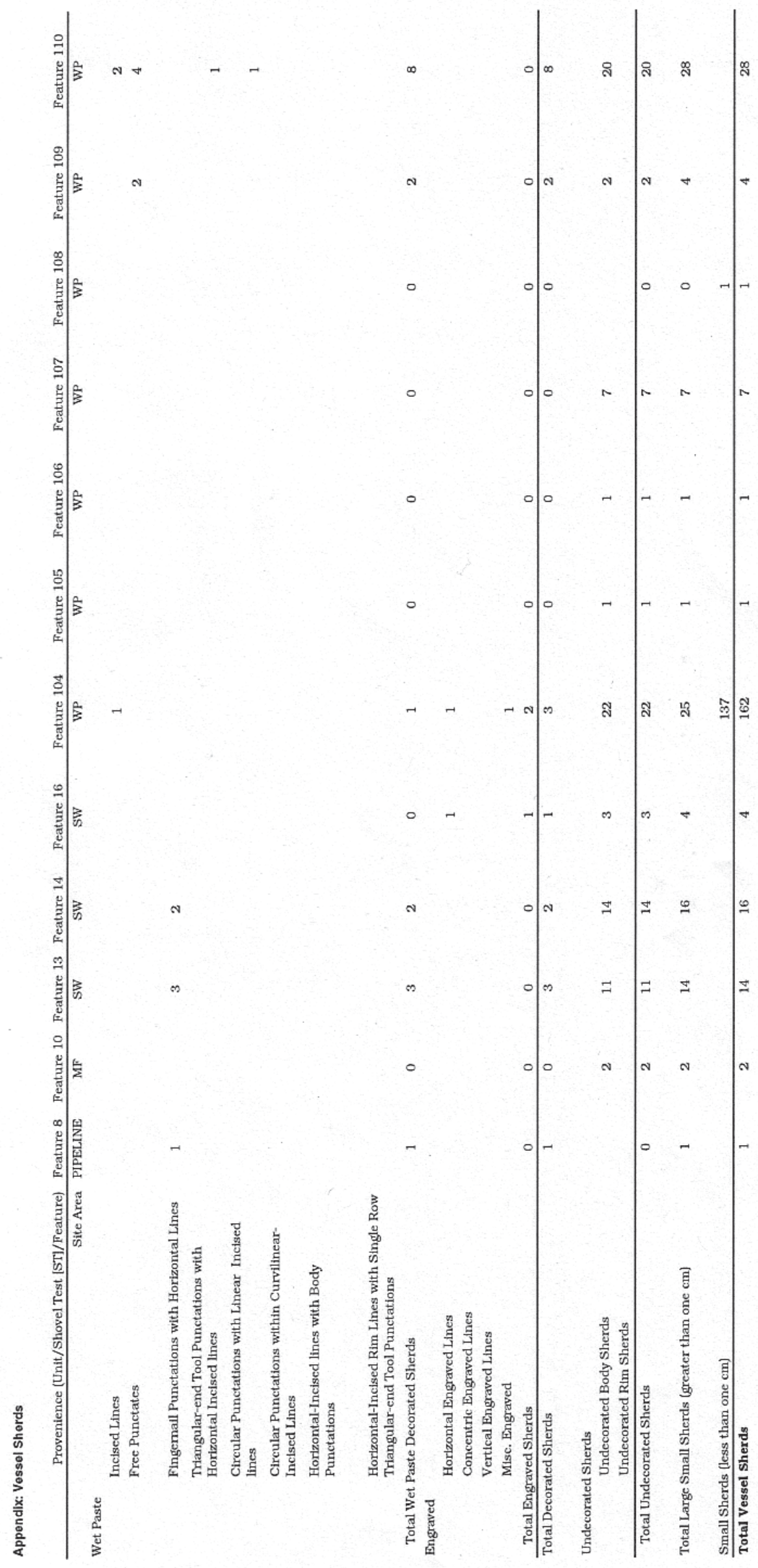




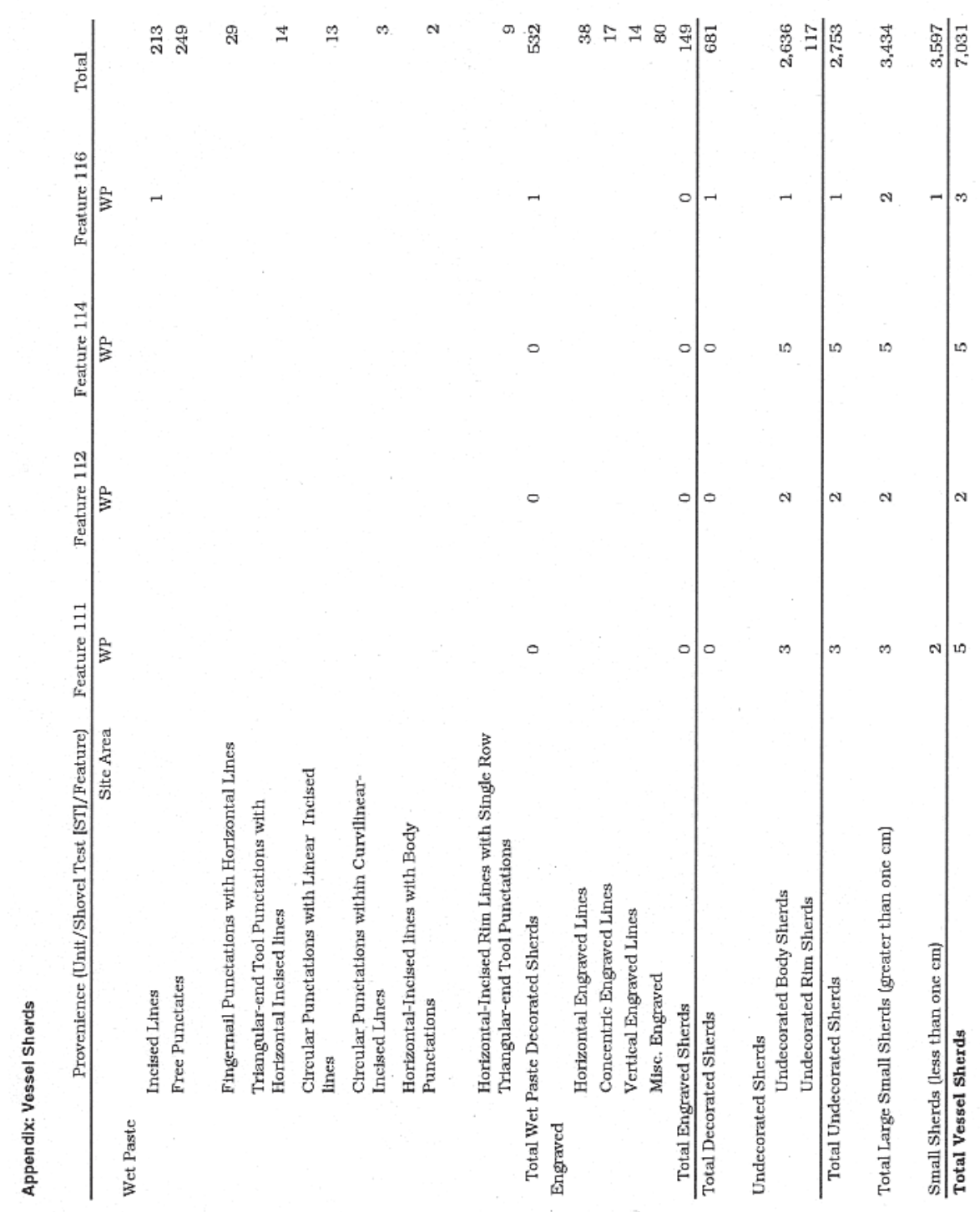

